TAARIK de Freitas Castilho

\title{
DISTINÇÃO ENTRE OBRIGAÇÕES DE MEIOS E OBRIGAÇÕES DE RESULTADO
}

Dissertação de Mestrado.

Orientadora: Professora Doutora DAISY GogLIANO

Faculdade de Direito da Universidade de São Paulo

São Paulo

2011 


\title{
DISTINÇÃO ENTRE OBRIGAÇÕES DE MEIOS E OBRIGAÇÕES DE RESULTADO
}

\author{
Dissertação de Mestrado apresentada como requisito \\ parcial para a obtenção do título de Mestre em Direito \\ Civil, sob a orientação da Profa. Dra. DAISY GoGLIANO.
}

FaCuldade de Direito da Universidade de São Paulo 
Dedico esta dissertação a meus pais, pelo constante apoio e paciência, tendo tanto me auxiliado, e a meu querido irmão, a quem espero fazer orgulhoso. 
Digna da mais profunda gratidão é a Profa. Dra. Daisy Gogliano, sempre pródiga em dispensar seus talentos invulgares na instrução de seus alunos, fazendo neles brotar calorosa curiosidade científica e criando em seu seio uma inesquecível amizade. 


\section{SUMÁRIO}

1 INTRODUÇÃ

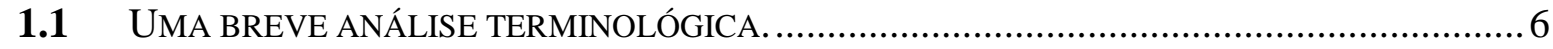

1.2 O CONTEÚDO DAS OBRIGAÇÕES E OUTROS GÊNEROS OBRIGACIONAIS. ......................... 12

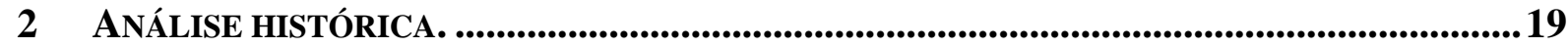

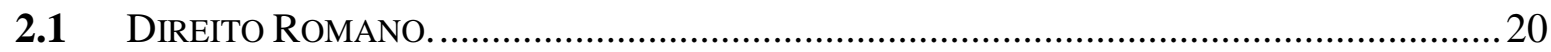

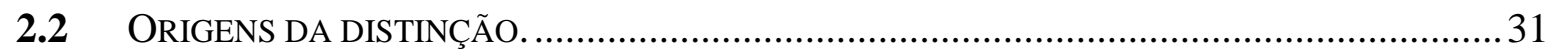

2.2.1 O surgimento da distinção na Alemanha. ................................................ 41

2.2.2 As obrigações de meio e de resultado na Itália (origem). ............................ 44

2.2.3 As obrigações de meio e de resultado na França (origem). ..........................54

3 A ESTRUTURA DA RELAÇÃO JURÍDICA OBRIGACIONAL.......................................................68

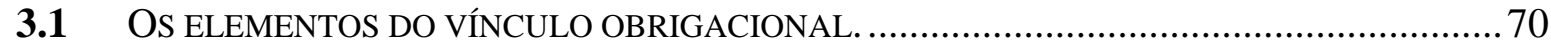

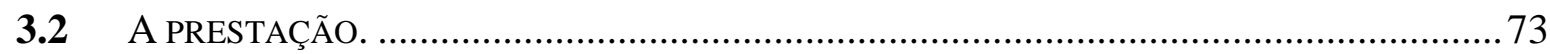

4 O TRATAMENTO DA DISTINÇÃO DO DIREITO ATUAL................................................76

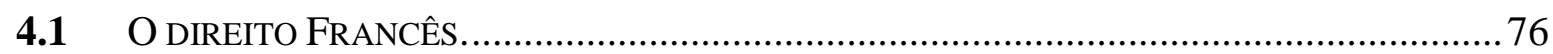

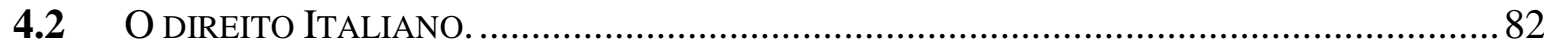

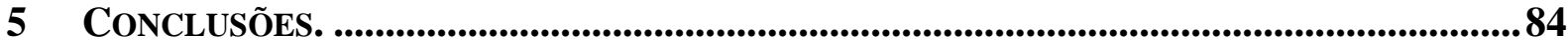

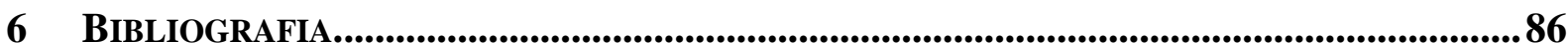




\section{INTRODUÇão.}

O presente trabalho orienta-se no campo dogmático do direitos das obrigações e, nestes termos, pretende deitar-se sobre a classificação das obrigações entre as de meios e as de resultado de forma a pesquisar sua base, seu campo de aplicação e potencial para orientar soluções concretas para os problemas do direito das obrigações.

Além disso, trata-se de uma pesquisa acerca de uma classificação e, enquanto tal pauta-se pela finalidade de trazer luz sobre os entes que classifica, esforçando-se por destacas suas similitudes e diferenças, contribuindo para a resolução de questões teóricas no campo do Direito.

É só através das classificações que se pode distinguem diferentes objetos que participam da formulação do conhecimento, é em razão das classificações que se pode agrupar aqueles de gênero similar. Sob este ponto de vista, por si só a pesquisa e formulação de classificações tem grande importância científica, merecendo atenção.

Cumpre-nos esclarecer que os juristas, acostumados às classificações, categoriais e generalizações, muitas vezes esquecem-se de sua importância, deixando sua análise sem a cura devida. ${ }^{1}$

A crise atual das categorias tradicionais das obrigações e, nesse particular das obrigações de meios e de resultado, sem dúvida alguma, se insere na moderna polêmica acerca dos conceitos jurídicos. ${ }^{2}$

Sob este aspecto, a aversão doutrinária que se vem sentido no contrato das obrigações de meios e de resultado, como aparelho puramente conceitual, pode ser entendida como reivindicação cultivada pela jurisprudência prática. Recolocar o jurista na simples e natural atividade de julgar os fatos é o mote. ${ }^{3}$

Desta forma, também se pretende aqui realizar a defesa dos conceitos tradicionais, instrumentos úteis e válidos de analiso do vínculo obrigacional e capazes de elucidar a norma aplicável ao caso concreto.

\footnotetext{
${ }^{1}$ MAZEUD, Henri. Essai de classification des obligations: obligations contractuelles et extra-contractuelle; “obligations detérminées" et "obligations générales de prudence et diligence". Revue Trimestrielle de Droit Civil. Paris, t. 35, 1936, p. 2.

${ }^{2}$ IRTI, Natalino. La polemica sui concetti giuridici. Rivista Trimestrale di Diritto e Procedura Civile. Milano, n. 1, Anno LVIII, 2004, p. 19.

3 BELISSENT, Jean. Contribution à l'analyse de La distinction des obligations de moyens et des obligations de résultat à propos de l'évolution des ordres de responsabilité civile. Paris: L.G.D.J, 2001, p. 486.
} 
Nesse quadro, o presente estudo espera esclarecer a validade da distinção entre as obrigações de meios e de resultado e sua utilidade para a resolução das questões atinentes ao adimplemento.

A cada espécie obrigacional corresponde uma forma de satisfação, atendendo ao interesse externo do credor.

A análise do adimplemento e, por seu intermédio, da satisfação do credor são problemas tornados presentes na sociedade atual, prolífica na conclusão de contratos despersonalizados, concluídos entre partes que sequer se comunicam, restando os destinos do vínculo obrigacional formado sujeito a fatores externos.

O estudo das obrigações de meios e de resultado pode-se justificar, ainda, pela polêmica que sempre mantive e mantem desde o seu surgimento, encontrando-se ainda sem solução questões como a da denominação utilizada, de seu campo de aplicação e da validade das conceituações formuladas.

A investigação que agora se realiza adotará o método dialético. Em tema cercado de polêmicas e opiniões antagônicas, o confronto de diversos posicionamentos será fundamental para que se possa informar acerca do atual estágio do debate.

Além disso, utilizar-se-á o método comparatístico, na medida em que é na doutrina e jurisprudência estrangeiras que podemos encontrar as grandes contribuições para análise do tema. Não se trata, entretanto, de falta de crença na doutrina pátria, o fato é que a distinção entre as obrigações de meios de resultado encontrou repercussão muito mais profunda entre outros países, especialmente França e Itália. 


\subsection{UMA BREVE ANÁLISE TERMINOLÓGICA.}

A classificação das obrigações segundo seu conteúdo, sendo de um lado de meios e de outro de resultado, cuja fama deve-se a Demogue, tornou-se tema largamente discutido entre os estudos do direito civil e, embora fortemente acolhida por inúmeros autores, não passou livre de acirradas críticas, objeções de ordem metodológica e prática.

Até mesmo a terminologia utilizada para designar as duas diferentes categorias de obrigações foi objeto de acaloradas discussões. Não é demais lembrar que os irmãos Mazeud, calorosos entusiastas da distinção, consideraram a terminologia utilizada por Demogue um pouco sibilina. ${ }^{4}$

Essas discussões quanto à terminologia, no entanto, mais que mero amor à tradição, pois tornadas passagem comum entre os estudiosos do tema, ${ }^{5}$ ganham importância na medida em que são capazes de sinalizar para o foco adotado pelos diversos autores na conceituação e classificação das obrigações segundo seu conteúdo.

Isso porque, não se pode esquecer, que a ciência jurídica, diversamente do que ocorre entre as ciências naturais, tem por objeto o agir do homem.

Nesse caso, a ciência e seu objeto pertencem a um mesmo e único mundo, o do pensamento e da vontade humanos, pois o dado analisado, a norma, cujo propósito é regular a vida, é concebida segundo esquemas e modelos típicos, usa e cria conceitos, fazendo com que a viva ela de elaborar conceitos sobre conceitos.

Estes conceitos jurídicos, entretanto, não são propriamente categorias teóricas, mas “categorias arbitrárias" que auxiliam o pensar sobre o agir. Trata-se, portanto, de pseudo-conceitos. $^{6}$

O direito faz-se, dessa forma, ciência eminentemente histórica, povoada de figuras produzidas pela vontade humana, constantemente criadas pelas normas elaboradas pelos diversos governos em diferentes épocas.

\footnotetext{
${ }^{4}$ MAZEAUD, Henri, MAZEAUD, Leon. Traité théorique et pratique de la responsabilité civile. Paris: Montchrestien, 1978, t. I, p. 108.

${ }^{5}$ Como forma de se demonstrar a flutuação na terminologia utilizada, temos André Tunc com as expressões "obrigações determinadas" e "obrigações gerais de prudência e diligência", Mengoni denomina as obrigações de meios de "obrigações de simples comportamento" e Betti as classifica como "obrigações de conduta".

${ }^{6}$ IRTI, Natalino. La polemica sui concetti giuridici. Rivista Trimestrale di Diritto e Procedura Civile. Milano, n. 1, Anno LVIII, 2004, p. 13.
} 
Assim, se é fácil convencer-se de que não é possível formular-se, no estudo do direito, verdadeiros conceitos, carregados de universalidade, quando a elaboração teórica deve servir às contingências práticas, quando o dado positivo analisado, a norma, é fruto da vontade e pode determinar-se com liberdade quase absoluta, ${ }^{7}$ pode-se, com tranquilidade, perceber a utilidade de uma breve análise terminológica, capaz de brevemente desvelar os elementos considerados importantes na formulação do conceito, ou pseudo-conceito, das obrigações de meios ou de resultado pela doutrina.

Apesar disso, não é de se esquecer que o papel do jurista é o do purificador e salvador, cujo dever é estabelecer a ordem e defender, mesmo diante da força da vontade legislativa, a continuidade do sistema, permanecendo aberto ao que se conserva do passado em cada uma das construções jurídicas.

Desta forma, se se pode sentir a "arbitrariedade" de cada uma das conceituações formuladas pelos doutrinadores, o que de um lado justifica uma breve analise da terminologia empregada, tal análise torna-se igualmente útil na busca de novos e mais apropriados conceitos, ou pseudo-conceitos.

Dito isso, podemos retornar à análise terminológica.

H. A. Fischer chamou de objetivas as obrigações que vinculavam o devedor à realização de um determinado resultado e subjetivas aquelas que lhe impunham um simples dever de esforço no sentido de realização de um fim visado pelas partes. ${ }^{8}$ Segundo ele o valor dogmático da classificação encontra-se na análise da responsabilidade civil por inadimplemento, enquanto nas obrigações subjetivas o conceito de fortuito perderia importância, já que qualquer evento externo capaz de impor esforço e diligência superiores àqueles de fato assumidos pelo devedor seriam suficientes para exonerá-lo; nas obrigações objetivas o elemento subjetivo aparece tão-somente de maneira negativa, ele qualifica o fato externo que tornou impossível a execução da obrigação. ${ }^{9}$

É bem ressaltar, no entanto, como nos ensina Mengoni, que há aqui uma confusão conceitual. A definição de diligência como conteúdo da prestação obrigacional nas chamadas obrigações subjetivas não se distingue daquela utilizada como medida da culpabilidade, opondo-se à negligência, no caso de responsabilização por inadimplemento.

\footnotetext{
${ }^{7}$ IRTI, Natalino. La polemica sui concetti giuridici. Rivista Trimestrale di Diritto e Procedura Civile. Milano, n. 1, Anno LVIII, 2004, p. 14.

${ }^{8}$ FISCHER, H. A. Vis major im Zusammenhang mit Unmöglichkeit der Leistung, p. 254. apud MENGONI, Luigi . op. cit., p.51.

${ }^{9}$ FISCHER, H. A. Vis major im Zusammenhang mit Unmöglichkeit der Leistung, p. 262-270. apud MENGONI, Luigi . Obbligazioni "di risultato" e obbligazioni "di mezzi". Milano: Francesco Vallardi, 1954, p.51-52.
} 
Desta forma, o ponto de distinção das obrigações, originariamente colocado em seu objeto, acaba por deslocar-se para a responsabilização civil. ${ }^{10}$

Quer nos parecer, desta forma, que do ponto de vista classificatório, a terminologia proposta seria criticável na medida em que busca definir-se pelos elementos diversos dos sistemas de responsabilidade civil percebido pelo autor tedesco que por qualidades ou elementos distintivos do vínculo obrigacional.

A divisão de obrigações de meios e obrigações de resultado, na linguagem de Osti, "dever de uma determinada diligência" e "dever de realizar um determinado resultado em concreto", ${ }^{11}$ presa em sua pureza dogmática, guarda estreita relação com um sistema binário do responsabilidade civil contratual, objetiva para a falta de obtenção de um resultado específico, subjetiva para a inobservância das obrigações de meios.

Do ponto de vista classificatório, quer nos parecer, entretanto, que melhor seria utilizar o termo obrigação, em lugar de dever, na medida em que este último deixaria de ligar a atividade específica do devedor para o adimplemento ao sentido de crédito e débito.

Todas as denominações adotadas parecem pouco aceitáveis e a essa sina, não escapa aquela proposta por Mazeud, que após ostensiva crítica a Demogue, propõe que se adote a terminologia obrigações determinadas e obrigações gerais de prudência e diligência. $^{12}$

Quer parecer, entretanto, que a proposta dessa nova denominação fez-se quase que arbitrariamente, já que parece esquecer-se que embora o direito das obrigações não reclame um conteúdo específico ou uso pré-definido da prestação, exige que seu objeto seja determinado ou determinável. Quanto ao comportamento obrigatório, que se cumpra de forma diligente, quanto ao bem devido, que se defina pelo tempo e lugar da prestação. ${ }^{13}$

Desta forma, embora Mazeud tenha pretendido atribuir às obrigações determinadas o sentido de que tenham seu objeto rigidamente definido por um resultado preciso buscado, por cuja realização o devedor responde salvo em caso fortuito ou força maior, não se pode esquecer que se apropria de terminologia reservada, tradicionalmente, ao objeto das obrigações e, vale dizer, ao requisito de validade dos negócios jurídicos.

A crítica que se pode fazer à sua proposta, contudo, não se encerra neste ponto.

\footnotetext{
${ }^{10}$ MENGONI, Luigi . op. cit., p.52-53.

${ }^{11}$ OSTI, Giuseppe. Revisione critica della teoria sulla impossibilita della prestazione. in Scritti Giuridici. Milano: Giuffrè, 1973, p. 123-124.

${ }^{12}$ MAZEAUD, Henri, MAZEAUD, Leon. Traité théorique et pratique de la responsabilité civile. Paris: Montchrestien, 1978, t. I, p. 108. MAZEUD, Henri. Essai de classification des obligations: obligations contractuelles et extra-contractuelle; "obligations detérminées" et "obligations générales de prudence et diligence". Revue Trimestrielle de Droit Civil. Paris, t. 35, p. 29.

${ }^{13}$ BIANCA, C. Massimo. Diritto Civile. Milano: Giuffrè, 1993, v. IV, p. 86.
} 
Ao utilizar-se da expressão "obrigação geral de prudência e diligência" pode-se dizer que o adjetivo "geral" refere-se ao elemento subjetivo da obrigação, trata da imposição de um determinado comportamento não a um só e único indivíduo, mas a um grupo particular de sujeitos, o que viria impedir que se analisasse uma obrigação geral no terreno da responsabilidade civil contratual, reservado à violação de obrigações determinadas. Embora Mazeud não seja explícito, utiliza-se do vocábulo para referir-se às obrigações surgidas de contratos ou da lei, dirigidas à satisfação plena do interesse do credor, todavia, se se utiliza principalmente dele para designar o vínculo obrigacional segundo o conteúdo do vínculo primário da obrigação, nada impede que a mesma terminologia seja aplicada para se distinguir uma prestação singular no todo de um mesmo vínculo obrigacional. ${ }^{14}$

Outra objeção que se pode levantar é que diligência não é um comportamento específico, mas antes um modo de comportar-se e, neste sentido, medida de um concreto dever de prestar.

É verdade que, do ponto de vista técnico jurídico, a palavra diligência, unida aos verbos prestar, usar, empregar, responder, adquirir um significado especial: não designa simplesmente uma atitude interior, uma propriedade do espírito humano, ao invés disso revela tal qualidade num "comportamento diligente"; e, portanto, o termo obrigação de diligência equivale ao dever de agir diligentemente diante de um determinado fim (tradução livre). ${ }^{15}$

Desta forma, todavia, a obrigação de comportar-se de forma diligente adquire o sentido de uma prestação concreta, um comportamento específico e qualificado, transformando-se de quadro comparativo segundo o qual se julga uma determinada conduta em resultado econômico específico e necessário à satisfação do credor.

Nesse ponto, a terminologia adotada por Demogue e tão criticada, tanto quanto aquela proposta por Mazeud, são acusadas de esquecerem-se da relatividade dos conceitos de meio e de resultado, já que um determinado fato, compreendido como meio necessário para que se atinja um fim específico, representa em si mesmo um resultado, quando considerado numa serie de eventos mais limitada.

Além disso, não se poderia conceber uma obrigação que não tenha por objetivo a produção de um resultado. O vínculo obrigacional implica um dever de dar/fazer/não fazer

\footnotetext{
${ }^{14}$ MENGONI, Luigi . op. cit., p. 03.

15 "È vero, dal punto de vitsta tecnico-giuridico, la parola diligenza, in unione coi verbi prestare usare impiegare rispondere, acquista uno speciale significato: non designa semplicemente um'attitudine interiore, uma proprietà dello spirito umano, bensì l'estrinsecazione di tale qualitá in um "comportamento diligente", e pertanto il termine obbligazione di diligenza equivale a dovere dia gire diligentemente in vista di um dato scopo" (MENGONI, Luigi . op. cit., p. 03)
} 
completado pelo dever de receber, de forma que não se vê sentido numa obrigação que não se dirija a produção de uma utilidade destinada à satisfação do credor, seja ela uma alteração no mundo de fatos ou uma atividade determinada. ${ }^{16}$

Isso, segundo nos parece, atende ao pensamento aristotélico no sentido de que o princípio da ação é sempre o propósito, já que não pode haver quem realize algo sem que o faça por um escopo, contudo, o seu fazer não é absolutamente um fim. O agir desencadeia-se em relação com outro e por causa de outro. ${ }^{17}$

Logo, parece justo o que se disse, que o princípio das ações é o homem; que a deliberação existe à-cerca das coisas que ele próprio pode operar; e que as ações são meios para o fim: já que o fim não pode nunca ser deliberado, mas sim o que diz respeito ao fim. ${ }^{18}$

Nesse quadro, não só a própria terminologia adotada parece desaconselhável, como se poderia dizer que a própria distinção proposta carece em absoluto de sentido, pois o objeto da obrigação, seja ele um bem ou um agir do devedor, são sempre resultados esperados para a satisfação do interesse creditício (prestação-resultado).

Contudo, como se verá com mais vagar oportunamente, enquanto nas obrigações de resultado, o prestação-resultado é igual ao bem ou agir que uma vez realizado satisfaz o interesse do credor, nas obrigações de meios, essa prestação-resultado, embora dirija-se à produção de resultado real no plano fático e que satisfará o interesse do credor, não é ele sempre esperado como fruto do cumprimento obrigacional, já que o seu vir a ser no mundo dos fatos depende de contingências que colocam-se além das forças do devedor, ainda que conduza-se ele segundo os meios considerados necessários para que se produza aquele resultado determinado. ${ }^{19}$

Ainda em respeito aos vocábulos utilizados na designação das obrigações de meios e de resultados, classificação que referida nos Princípios UNIDROIT sobre contratos comerciais internacionais parece ter sido aceita pelos diversos países que os adotam, temos "obligación de resultado" e "obligación de emplear los mejores esfuerzos"; "obbligazione di risultato" e "obbligazione di mezzi", "obligation de résultat" e "obligation de moyens"; "duty to achieve a specific result" e "duty os best efforts"; e "Pflicht, einem bestimmten Erfolg zu erzielen" e "Pflicht zum Eisatz aller Kräfte". ${ }^{20}$

\footnotetext{
${ }^{16}$ MENGONI, Luigi . op. cit., p. 04.

${ }^{17}$ ARISTÓTELES. A Ética. Tradução de FONSECA, Cássio M. São Paulo: Atena Editora, 1950, p. 81.

${ }^{18}$ ARISTÓTELES. op. cit., p. 67.

${ }^{19}$ D'AMICO, Giovanni. La responsabilità ex recepto e la distinzione tra obbligazioni “di mezzi" e "di risultato" - contributo alla teoria della responsabilità contrattuale. Napoli: Edizioni Scientifiche Italiane, 1999, p. 162 e ss.

${ }^{20}$ MINASSE, Elton. Contribuição ao estudo das obrigações "de meio" e de "resultado". 2005.

Monografia (Mestrado) - Faculdade de Direito da Universidade de São Paulo, p. 101.
} 
Diante de todas as terminologias utilizadas no estudo da classificação das obrigações segundo seu conteúdo, resta decidir qual delas adotar.

Como bem se percebe, todas são passíveis de graves de indisfarçáveis críticas, sem que, contudo, tenham jamais alcançado a notoriedade daquela nomenclatura proposta por Demogue em seu Traité, o que quer nos parecer seja razão suficiente para preferi-la às demais, evitando-se assim desentendimentos e equívocos. 


\subsection{O CONTEÚDO DAS OBRIGAÇÕES E OUTROS GÊNEROS OBRIGACIONAIS.}

A elaboração de classificação das obrigações segundo seu conteúdo não parece contemplar apenas as obrigações de meios e de resultado, embora muitos estudiosos procurem colocar entre essas categorias as obrigações de garantia e as promessas de fato de terceiro. $^{21}$

A pesquisa das obrigações do ponto de seu conteúdo, objeto, sem descer em exaustiva casuísticas, nos leva a examinar, antes de tudo, o que exatamente cumpre o devedor prestar ao credor para que se libere. Nesse quadro, situações há em que lhe cumprirá apenas realizar uma atividade que pode ser valorada apenas segundo a diligência, do que seria exemplo o contrato de prestação de serviço.

Entretanto, outras situações há em que o devedor se compromete à entrega de um determinado resultado útil ao credor, como no caso do contrato de empreitada, em que se compromete a, de acordo com as forças de seu trabalho, entregar produzir uma determinada utilidade e entrega-la a seu credor.

Nestes dois simples exemplos podemos encontrar as obrigações de meios e de resultado.

Contudo, existem situações em que a prestação não assumiria nem a figura de uma atividade valorável segundo os ditames da diligência, sequer produziria um resultado útil, trata-se das obrigações de garantia, em que a eliminação do risco que pesa sobre o credor representa por si mesmo o bem de vida buscado. ${ }^{22}$

Essa obrigação de garantia, tão bem descrita por Betti em seu exemplo dos contratos de seguro, comumente diz-se ter tido origem pretoriana, em arresto da Corte de Cassação francesa do ano de 1911 "Compagnie générale tansatlantique c/ Zbidi Hamida Bem Mahoud", em que se reconheceu a obrigação acessória do transportador garantir a segurança de seus passageiros. ${ }^{23}$

\footnotetext{
${ }^{21}$ Fabio Konder Comparato, por exemplo, acaba por revisar posicionamento esboçado em seu Essai d'analyse dualiste de l'obligation en droit privé, oportunidade em que considerou as obrigações de garantia como espécie de obrigações de resultado, opinião similar àquela adotada por Philippe le Tourneau (Droit de la Responsabilité e des Contrats. Paris: Dalloz, $8^{\text {a }}$ ed., 2010, p. 922 e ss.). Massimo Bianca, entre outros, considera as promessas de fato de terceiro e as obrigações de garantia como espécies de obrigações de resultado (op. cit., p. 72).

${ }^{22}$ COMPARATO, Fábio Konder. Obrigações de meio, de resultado e de garantia. in Enciclopédia Saraiva do Direito. Coordenação de Rubens Limongi França. São Paulo: Saraiva, v. 55, p. 429.

${ }^{23}$ TOURNEAU, Philippe le. op. cit., p. 923.
} 
Cumpre-nos, entretanto, aventar a possibilidade de tratar-se "l'obligation de securité" de uma evolução da teoria da garantia apresentada por Sainctelette, surgida como forma de resolver a crise decorrente das dificuldades enfrentadas por empregados na obtenção de ressarcimento pelos danos sofridos em acidentes de trabalho e dos passageiros, nos casos de prejuízos experimentados em decorrência dos contratos de transporte.

Sainctelette propõe, no final do século XIX, que o transporte de pessoas é objeto de um contrato pelo qual o condutor torna-se garante da segurança do passageiro durante a viajem e, em caso deste sofrer danos no decorrer da viagem, caberia ao condutor provar que os prejuízos sofridos decorreram de caso fortuito ou força maior. ${ }^{24}$

Esta obrigação acessória de garantia, segundo seu autor, apresentaria a vantagem ao passageiro vitimada de obter reparação com maior certeza, rapidez e mais facilmente. Não mais sobre ele pesaria o risco de arcar com os prejuízos sofridos nos casos em que o acidente sofrido não pudesse ser adequadamente explicado, pois bastaria à vítima provar que o condutor deixar de executar suas obrigações. ${ }^{25}$

Qual seria, entretanto, o obstáculo que levou os tribunais a deixarem de aplicar a teoria proposta por Sainctelette para formular obrigação acessória de garantia em termos absolutamente similares décadas mais tarde.

Segundo nos ensina Belissant, a razão do fracasso da teoria da garantia poderia ser encontrada no fato de ter o autor buscado dar resposta aos acidentes decorrentes do transporte de pessoas por meio de uma extensão das obrigações que pesavam sobre o transportador de coisas, nomeadamente seu dever de reparar os danos ocasionados aos produtos transportados, ressalvado o caso fortuito ou de força maior. ${ }^{26}$

Sainctelette explica que o principio contido no artigo 1784 do Código Civil não é nem mais nem menos que uma consequência ordinária e equânime do "contrato de transporte de mercadorias" ditada pelo bom senso e pela boa-fé; de qualquer maneira, a disposição desse artigo seria

\footnotetext{
24 "le transport des personnes forme l'objet d'um contrat ... par ce contrat, le voiturier se rend garant de la sûreté du voyageur pendant le Voyage et du chef du Voyage; en cas d'inexécution de cette obligation conventionnelle, c'est au voiturier de prouver que l'accident de transport don't se plaint le voyageur provident de qualque cause étrangère qui ne lui est pas imputable: cas fortuit, force majeure, dégaut de prévoyance ou de precaution du voyager" (SAINCTELETTE, Charles. De la responsabilité de la garantie. p. 87-88, apud BELISSENT, Jean. Contribution à l'analyse de La distinction des obligations de moyens et des obligations de résultat à propos de l'évolution des ordres de responsabilité civile. Paris: L.G.D.J, 2001, p. 252-253.

${ }^{25}$ SAINCTELETTE, Charles. De la responsabilité de la garantie. p. 109, apud BELISSENT, Jean. op. cit., p. 253.

26 "Article 1784

Ils sont responsables de la perte et des avaries des choses qui leur sont confiées, à moins qu'ils ne prouvent qu'elles ont été perdues et avariées par cas fortuit ou force majeure".
} 
supérflua naquilo em que "se limita a exprimir uma consequência que a razão e a equidade trazem, segunda sua natureza, à obrigação de levar um objeto de um lugar a outro (tradução livre). ${ }^{27}$

A proposta de extensão do disposto no art. 1784 do Code Civil deixaria de ser admissível na medida em que os passageiros mantêm, no correr do transporte, uma certa medida de liberdade de locomoção que lhes proporciona as mais diversas oportunidades de sofrerem danos em situações bastante similares àquelas que enfrentariam encerrados no conforto de seus lares ou locais de trabalho. Aliás, a maior parte dos acidentes que se verifiquem em passageiros de transporte ferroviário deriva de sua própria conduta imprudente. $^{28}$

Diante de tais circunstâncias, não é passível de compreensão a resistência jurisprudencial inicial, deixando de adotar a teoria da garantia, para vir enunciar a teria da obrigação acessória de assegurar quase que em seus mesmos termo em 1911.

De qualquer forma, as obrigações de garantia, neste quadro que se vem de esboçar, seriam sempre obrigações contratuais acessórias e resguardariam apenas as pessoas.

Acessória, pois dependeria sempre de uma obrigação principal que deve apresentar dois aspectos, não reduzir-se a um dever de resguardar o manter a saúde e integridade da pessoa assegurada ou garantida, pois se trata de obrigação acessória de assegurar o credor de quaisquer consequências danosas decorrentes da prestação da obrigação principal, assim, sob o médico não pesaria qualquer obrigação de garantia no sentido que aqui se adota; por fim, sempre haveria de ter origem contratual. ${ }^{29}$

Em seu surgimento, a obrigação de garantia foi apresentada de maneira bastante rigorosa visando a resguardar a integridade física dos passageiros. Assim, concebia-se verdadeira responsabilidade objetiva do transportador para com a segurança e integridade do passageiro, pelo que melhor seria chama-la "garantia de reparação" que obrigação de garantia ou de segurança.

Desse ponto, passou a ser vista como obrigação tipicamente de resultado, de forma que ao condutor ou transportador caberia apresentar o passageiro em seu destino são e

\footnotetext{
27 “Sainctelette explique que le principe contenu à l'article 1784 du Code Civil n'est ni plus ni moins qu'une ordinaire et équitable suite du "contrat de transport de marchandise » dictée par "le bon sens et la bonne foi ; en quelque sorte, la disposition de cet article serait superflue en ce qu'il « se borne à exprimer une suite que la raison et l'équité donnet, suivant sa nature, à l'obligation de porter un objet d'un lieu à un autre »" (BELISSENT, Jean. op. cit., p. 253).

${ }^{28}$ BELISSENT, Jean. op. cit., p. 254.

${ }^{29}$ TOURNEAU, Philippe le. op. cit., p. 923-924.
} 
salvo, sem o que não se exoneraria o aquele, salvo em casos de força maior ou caso fortuito. $^{30}$

Com a gradativa expansão do terreno das obrigações de garantia do terreno dos contratos de transporte para todos os contratos em que a prestação principal colocasse em risco o devedor, doutrina e jurisprudência passaram por uma primeira fase de atenuação, passando a ser considerada típica obrigação de meios, por força da qual o devedor haveria de tomar, tão-somente, as precauções necessárias para assegurar a integridade do credor. Nesse caso, caberia a ele, na eventualidade de sofrer danos, o ônus de provar a culpa da outra parte. $^{31}$

Num terceiro momento, a obrigação de garantia passou a ser considerada pela jurisprudência, ora como de meio, no início e fim da viagem, por exemplo, e de resultado em seu correr. ${ }^{32}$

Quer nos parecer, entretanto, em que pese o posicionamento de diversos autores no sentido de que poderia ser enquadrada como espécie de obrigação de resultado, de meios, ou mesmo de ambas, decompondo-se a prestação principal em diversas fases, cada uma tornada diversa pela extensão da obrigação de assegurar que pesa sobre o devedor, a obrigação de garantia é de ser considerada gênero autônomo e específico de obrigação.

Não é demais lembrar que, sendo ela acessória ou não, a satisfação do interesse do credor corresponde à assunção do risco pelo devedor.

A utilidade esperada por aquele reside na garantia, na segurança, que este proporciona, comprometendo-se a reparar as consequências da ocorrência de um determinado evento temido. Neste quadro, pode-se dizer que o devedor assegurador traz ao credor assegurado certa medida de segurança, de tranquilidade, a liberdade de preocupações com as consequências que adviriam da realização de um fato específico, na medida em que poderá ele conseguir um ressarcimento, uma reparação, total ou parcial, daquele que com ele se comprometeu. ${ }^{33}$

Com efeito, no contrato de seguro a indenização pode nunca vir a ser paga, não se verificando o sinistro, nem por isso o contrato de seguro deixaria de ser adimplido, pois

\footnotetext{
${ }^{30}$ Diversos autores permanecem partidários desta solução, entre eles Plilippe le Tourneau (op. cit., p. 926 e ss.), Geneviève Viney (Traité de Droit Civil. Les Obligations. La responsabilité: conditions. Coordenação de Jacques Ghestin. Paris: L.G.D.J., 1982, p. 486 e ss.) e Massimo Bianca (op. cit., p. 72).

${ }^{31}$ BELISSENT, Jean. op. cit., p. 319.

32 TOURNEAU, Philippe le. op. cit., p. 926.

${ }^{33}$ BETTI, Emilio. Teoria Generale delle Obbligazioni. Milano: Giouffrè, 1953, v. I, p. 41-42.
} 
seu objeto é a própria segurança decorrente da apólice, libertando-se o segurado do risco que de outra forma pesaria sobre ele. ${ }^{34}$

Nesse diapasão, além do exemplo do contrato de seguro, podemos encontrar as chamadas garantias autônomas, variantes do Garantieverträge do Direito Alemão; ${ }^{35}$ a obrigação do fiador, a obrigação do contratante em relação aos vícios redibitórios nos contratos comutativos. ${ }^{36}$

Fortes nesses motivos é que podemos concluir que são, as obrigações de garantia, um tertium genus na classificação das obrigações segundo seu conteúdo.

Resta agora saber como compreender a promessa de fato de terceiro.

A promessa de fato de terceira, em suas várias formas de manifestação, é área demasiado fértil para se testar a viabilidade das obrigações de meio e de resultado.

Aliás, quanto à sua classificação jurídica, podemos encontrar três orientações principais.

A primeira, que bem se pode encontrar na jurisprudência fartamente, considera a promessa de fato de terceiro como uma obrigação de fazer. Nesse caso, a prestação consiste exatamente num conduzir-se de forma que o terceiro cumpra o fato prometido.

Ocorre, contudo, que uma tal tese não se sustenta diante da norma posta, na medida em que a falta de realização do fato por parte do devedor, em que pese a mais ampla e constante atuação do promitente, não é suficiente para escusá-lo do dever de indenizar. ${ }^{37}$

Ao lado desta surgiu outra, fundada na elegante saída de considerar a promessa de fato de terceiro uma modalidade das obrigações de garantia. Isso porque o devedor promitente não poderia ver-se obrigado aquilo a que fuja sua vontade, A promessa de fato de outrem daria surgimento, portanto, a um obrigação de garantia compreendida como a assunção do risco de um evento desfavorável. Assim, o promitente assumiria o risco de que o fato prometido não se realizasse, caso em que lhe caberia o ressarcimento. ${ }^{38}$

A adoção da teoria da obrigação de garantia, nesse ponto, admite indisfarçavelmente a noção de que a conduta de terceiro prometida foge inescapavelmente

\footnotetext{
${ }^{34}$ BETTI, Emilio. Teoria Generale delle Obbligazioni. Milano: Giouffrè, 1953, v. I, p. 42-43.

${ }^{35} \mathrm{O}$ impulso para tal categoria negocial tem sua origem na atividade bancárias no comércio internacional, em que a necessidade de tutela dos interesses do credor é amis ampla, pela incidência de riscos que não se verificam nas mesmas relações quando levadas a cabo dentro das fronteiras de um só Estado.

Entre tais riscos pode-se incluir as medidas de controle de fluxo de capital, o confisco de capital estrangeiro ou mesmo o desconhecimento normativo pelas partes envolvidas, enquanto estrangeiros. (MINASSE, Elton. op. cit., p. 103).

${ }^{36}$ COMPARATO, Fábio Konder. op. cit.,p. 429.

37 “Art. 439. Aquele que tiver prometido fato de terceiro responderá por perdas e danos, quando este o não executar."

${ }^{38}$ BIANCA, C. Massimo. op. cit., p. 119.
} 
à esfera de controle do promitente. Desta forma, na medida em que o fato prometido é estranho ao devedor, trata-se de conferir à promessa o único efeito de garantia.

Trata-se, aqui, de se considerar que a vontade de terceiro, como determinante para a verificação do fato, acaba por esvaziar o conteúdo da prestação do devedor promitente, tornada irrelevante, na medida em que o resultado prometido depende da atuação autônoma e livre de terceiro.

Entretanto, é de se considerar que tal posicionamento peca ao confundir o conceito de álea, verificado nas obrigações de garantia, com o de impossibilidade da prestação.

Como se pode observar na, promissio facti alieni a impossibilidade de realização do resultado é apenas relativa, pois a interferência do promitente na vontade de outrem, na medida em que não seja suficiente para produzir o resultado, é de se considerar apenas impossibilidade subjetiva e relativa. Noutros termos, na promessa de fato de terceiro, afora os casos de efetiva impossibilidade originária, pois prometido aquilo que é impossível a terceiro, a dificuldade enfrentada pelo promitente para a realização do resultado prometido não destoa daquela que ordinariamente se verifica nos casos de uma outra prestação qualquer.

Isso sem dizer que embora o terceiro decida autonomamente sobre o cumprimento ou não do fato prometido, pode o devedor promitente legitimamente influir sobre seu comportamento, levando-o a realizar tudo quanto prometera.

Seria, por exemplo, o caso de um terceiro já obrigado anteriormente frente ao promitente ou este esteja autorizado a obrigar-se em seu nome, mas por conta de terceiro.

Diferentemente do evento assegurado, em que a ocorrência é estranha à intervenção do segurador, o fato de terceiro é por sua vez um evento para o qual o devedor pode e deve concorrer para realizar (tradução livre). ${ }^{39}$

Diante do claro insucesso jurisprudencial da tese das promessas dos fatos de terceiro como obrigações de meio e da consequente indiferença que poderia surgir da aplicação da teoria da garantia nesse caso, na medida em que o promitente devedor a nada mais estaria obrigado, senão ao ressarcimento do credor, diminuindo sobre maneira as chances deste de obter o objeto primário de seus interesses, o fato prometido, exsurge a tese das obrigações de resultado.

\footnotetext{
39 “A differenza dell'evento assicutato, il cui accadimento è estraneo all'intervento dell'assicutaorek il fatto del terzo è quindi un evento che il debitore può e deve concorrere a realizare" (BIANCA, C. Massimo. op. cit., p. 119.
} 
Para os partidários da tese das obrigações de resultado, ${ }^{40}$ a prestação devida não é exatamente a atividade direta no sentido de produzir um determinado resultado útil para o credor, mas antes obriga-se ele a produzi-lo.

Esta teoria tem a grande vantagem de transformar o fato de terceiro, compreendido na teoria da garantia como condição, elemento acidental, em objeto imediato do empenho do devedor promitente. ${ }^{41}$

É de se notar que o dado normativo inegavelmente influiu bastante na abordagem teórica que se apresentou a respeito da promessa de fato de terceiro.

Isso não é dizer, todavia, que não é possível, apenas do ponto de vista teórico, defender a classificação de tal espécie de obrigação no gênero das obrigações de resultado. $\mathrm{O}$ que se alcança definindo-se o vínculo interno entre a promessa e o fato de terceiro, este considerado, do ponto de vista do promitente, como o resultado devido da prestação prometida ao devedor, como o momento final da atividade do devedor, como elemento constitutivo dessa atividade, na medida em que o fato pudesse se produzir, em grande parte, independentemente da vontade do devedor promitente. ${ }^{42}$

Diante disso, podemos concluir que quem promete fato de terceiro se obriga em vista de um resultado, e a falta de sua verificação constitui inadimplemento, de forma que por este inadimplemento reponde o devedor, salvo se o terceiro deixou de praticar o ato por força de um evento externo e não previsível e insuperável apenas com o esforço diligente adotado pelo promitente devedor (caso de falência do terceiro, por exemplo).

\footnotetext{
${ }^{40}$ OSTI, Giuseppe. Contratto. in Novissimo Digesto Italiano. Torino, 1959, v. IV, p. 526. BIANCA, C. Masimo. op. cit., p. 120.

${ }^{41}$ OSTI. Giuseppe. Contratto. op. et loc. cit.

${ }^{42}$ CARBONE, Enrico. Diligenza e risultato. Torino: Giappichelli, 2007, p. 143.
} 


\section{ANÁLISE HISTÓRICA.}

O estudo e análise história do direito e de seus institutos é muitas vezes tratada com um condescendente desdém, por aqueles que pretendem e importam-se apenas em ocupar-se do direito positivo. Os juristas que se interessam por ela, quase sempre à custa de investigações muito longas e muito laboriosas, são freqüentemente acusados de pedantismo, o que certamente aqui não se pretende, especialmente porque falta ao autor a erudição necessária.

Contudo, quanto mais avançamos no direito civil, mais constatamos que a História, muito mais do que a Lógica ou a Teoria, é a única capaz de explicar o que as nossas instituições são, as que e porque é que são as que existem. ${ }^{43}$

${ }^{43}$ PAGE, Henri de. Traité de Droit Civil Belge. Bruxelles: Emile Bruylant, 1942, t. VI, p. 806. 


\subsection{DiREITO ROMANO.}

Os romanos não são, certamente, o primeiro povo a conhecer um direito das obrigações - Roma estava ainda em estado clânico na época em que, no Egito e na Grécia, o direito já tinha atingido uma forma individualista, o que somente viria a ocorrer para o povo do Lácio no curso dos séculos I e II de nossa era ${ }^{44}$-, entretanto, são os primeiros a desenvolver um corpo de normas coerentes, um conjunto de definições e classificações que inspiraram a maior parte das legislações ocidentais.

Em Roma é que se vê, pela primeira vez entre os povos antigos, um inegável domínio do direito, o que explica sua grande influência sobre os sistemas jurídicos dos povos ocidentais. Este alto grau de perfeição, no entanto, não se atingiu num só golpe, a história do direito Romano é uma história de 22 séculos, transitando do século VII a.C. ao século VI de nossa era, época de Justiniano e de sua grande obra de codificadora, prolongando-se, então, até o século XV no império Bizantino.

Este imenso período da história humana é, tradicionalmente e por comodidade didática, dividido, segundo sua evolução interna, em período do direito quiritário, período do clássico e período pós-clássico, ${ }^{45}$ divisão que se adotará no presente trabalho no curso da investigação da estrutura das obrigações no direito romano e de seu conteúdo.

Cumpre, no entanto, fazer duas observações pontuais. A historia do direito romano, e neste ponto, a do direito das obrigações, aparece numa multiplicidade de fontes, de órgãos dotados de poder normativo, o que se percebe em todo o decorrer do direito romano. Além disso, cumpre sempre lembrar que o povo romano tinha uma concepção de direito essencialmente prática e, avessa às formulações teóricas.

Não se trata de um direito voltado à uma arquitetura científica. A jurisprudência romana nunca atribuiu a si o dever de criar e enquadrar em sistemas e categorias o direito. Não se vislumbra um esforço de sistematização e classificação como o exigem as regras da lógica. $^{46}$

${ }^{44}$ GILISSEM, John. Introdução Histórica ao Direito. Tradução de HESPANHA, Antônio Manuel e MALHEIROS, Manuel Luís Macaísta. Lisboa: Fundação Calouste Gulbenkian, $5^{\mathrm{a}}$ ed., 2008, p. 80.

${ }^{45}$ CORREIA, Alexandre, SCIASCIA, Gaetano. Manual de direito Romano. Rio de Janeiro : Livros Cadernos Ltda. Guanabara, Série "Cadernos Didáticos", p. 16-17.

${ }^{46}$ GOGLIANO, Daisy. Tratativas Pré-contratuais (bases de uma teoria). 2009. Tese (Livre Docência) Faculdade de Direito da Universidade de São Paulo, p. 16. 
Ainda assim tem se afirmado sem dúvida alguma que o direito romano conheceu e adotou noções que correspondiam à distinção entre as obrigações de meios e de resultado, o que certamente merece breve análise.

O período arcaico do direito romano compreende a monarquia e os primeiros séculos da República, cuja metade do segundo século, com a conquista da bacia do mediterrâneo.

Em sua origem, nos séculos VIII e VII a.C, Roma era dominada pela organização clânica das grandes famílias, as gentes, e a autoridade do chefe era quase ilimitada. ${ }^{47}$ Era uma solidariedade ativa e passiva que ligava entre si todos os membros da gens e a terra, embora objeto de apropriação, era inalienável. ${ }^{48}$

Este direito arcaico é, e neste particular se assemelha ao de todas as demais sociedades antigas, marcadamente religioso. Os preceitos que regem a vida dos homens são de ordem sagrada, o fas domina o jus. ${ }^{49}$

Além disso, é o direito de um povo ligado à terra. O romano desta época é, antes de tudo, um camponês e seu direito, portanto, é de um mundo rural, cujo fim principal é regular as questões da terra, de seus marcos divisores, as querelas de vizinhança e do resguardo dos rebanhos.

Trata-se de um direito essencialmente consuetudinário, eram apenas os sacerdotes, os pontífices, que conheciam as formas rituais e as interpretavam, segredos que guardaram até 300-250 a.C. Ademais, parece não ter havido grande atividade legislativa na época da realeza nem no início da República, quando a lei começa a entrar em concorrência com o costume enquanto fonte do direito. ${ }^{50}$

A transição do direito de caráter religioso operou-se lentamente ao longo de vários séculos, como fruto de duras e inúmeras lutas entre patrícios e plebeus. O patriciado tinha grandes interesses na manutenção das instituições tradicionais, aliás, até o ano 254 a. C.

\footnotetext{
${ }^{47}$ Não é por outra razão que os futuros nubentes, mesmo antes de atingirem a puberdade, viam se ligados entre si pelas estipulações realizadas por seus pater famílias, determinando seu casamento futuro (sponsais), o que coibia a conclusão de matrimônio diverso sob pena de multa (stipulatio poenae) ou de serem perdidas as arras nupciais, o que igualmente contribuia para e evitar a ascensão inadequada das camadas sociais mais baixas (COSTA, Carlos Celso de Orcesi da. Tratado do Casamento e do Divórcio. São Paulo: Saraiva, 1987 , v. I, p. 33-34).

${ }^{48}$ GILISSEM, John. op. cit., p. 84.

${ }^{49} \mathrm{O}$ jus é o direito de origem humana, criado dar regular a vida em sociedade, ao fas, de outra parte, é o direito de origem divina, um conjunto de regras de caráter religioso, cuja observação se impunha nas relações entre os homens e os deuses e que visava, predominantemente, a regular o direito público e, no privado, as relações entre famílias (ALVES, José Carlos Moreira. Direito Romano. Rio de Janeiro: Forense, 14 ed., 2008, p. 80).

${ }^{50}$ É de se notar que teriam havido cerca de 800 leges rogata no período republicano, cujo assunto era, predominantemente, matéria de política e economia, foram somente 26 as leis que tratavam, efetivamente, de direito privado (GILISSEM, John. op. cit., p. 84).
} 
todos os pontífices eram de origem patrícia. Foi somente naquele ano que o primeiro plebeu ascendeu ao pontificado. Trata-se de Tibério Coruncânio, que promoveu um movimento de ensino e divulgação do direito ao povo. ${ }^{51}$

A reivindicação de que o direito fosse por todos conhecido, reclamação da plebe, que ignorando os costumes em vigor na cidade e suas interpretações pelos pontífices, queixava-se do arbítrio dos magistrados patrícios, é que pode se considerar um marco da laicização do direito romano. ${ }^{52}$

A face normativa do direito romano, cujo mais famoso expoente é a Lei da XII Tábuas, mais pela importância histórica que as discussões entre patrícios e plebeus apresentou para a antiga Roma que por seu conteúdo - não se tratou de um código no sentido moderno do termo, na medida em que trata-se de uma redução em escrito de uma série de costumes em fórmulas lapidares -, vê-se na lex, ato emanado das autoridades públicas, apenas os magistrados superiores (cônsules, pretores, tribunos, ditadores) tinham sua iniciativa, promulgando um texto (rogatio) que era afixado (promulgatio) por certo tempo, para ser então, votado nos comícios curiais ou centuriais, estes mais comuns, sobretudo entre os séculos V e IV a.C., ou comícios das tribos, desde a Lex Hortensia (287 a.C.). ${ }^{53}$

É nesse quadro, aqui brevemente delineado, que se insere a questão da origem do direito das obrigações, problema que desde há muito preocupa os estudiosos do direito romano e que tem dado azo a numerosas e diferentes hipóteses, todas elas, em maior ou menor grau, fazem referências a períodos muito antigos, anteriores à formação da civitas e de quando não nos chegaram quaisquer fontes seguras.

Como nos ensina Eduardo Volterra a este respeito, ${ }^{54}$ alguns teóricos fazem referências às relações que se pensa existirem entre os agrupamentos gentílicos, partindo

\footnotetext{
${ }^{51}$ MEIRA, Sílvio A. B. Instituições de Direito Romano. $3^{\text {a }}$ ed. São Paulo: Max Limonad, 1968, p. 37.

${ }^{52}$ Foi por força destes aguçados conflitos que, segundo a tradição lendária, no ano 462 a.C., o tribuno C. Terentilio Arsa, teria proposto que se criasse quinqui viri legibus de imperio consulari scribendis. Instituído esse conselho e diante da forte reação contrária dos patrícios, a proposta teria sido reenviada e reapresentada no ano seguinte a todos os tribunos, para então, diante das divergências entre cônsules e tribunos, decidir-se pelo aumento de seu próprio número. Foi somente no ano 454 a.C. que, tendo abandonado a proposta inicial, apresentou-se nova proposta aos patres, solicitando-se que se comunicasse a patrícios e plebeus o direito vigente.

Aceita a proposta, mas em função da divergência entre os legisladores (não sabiam se deveriam compor-se somente de patrícios ou se de patrícios e plebeus), decidiu-se enviar uma delegação a Atenas para que fossem estudadas as leis de Sólon. Tendo retornado a delegação de legisladores, nomearam-se os decemviri e, sob a direção de Apio Claudio, redigiram-se dez tábuas de leis, mais tarde complementadas, aquelas duas faltantes, por uma nova reunião de diferentes decemviri (GROSSO, Giuseppe. Lezioni di Sotria del Diritto Romano.

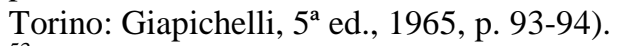

${ }_{53}^{5}$ GILISSEM, John. op. cit., p. 85-86.

${ }^{54}$ Instituciones de Derecho Privado Romano. Madrid : Civitas, 1991, p. 450-453.
} 
do pressuposto, neste particular não demonstrado, senão indemonstrável, de que as relações havidas entre tais grupos seguiam uma estrutura e teriam características comuns, repetindo-se constantemente, tendo sido logo acolhidos na organização da civitas romana e que, portanto, deram base às instituições jurídicas no direito romano, entre elas, o conceito de obrigações.

Para outro grupo de estudiosos do direito romano, no entanto, a evolução do direito das obrigações seguiria um desenrolar mais ou menos uniforme entre os povos da antiguidade, e, assim, ligam o problema da origem e a primitiva noção de obrigação à idéia de delito e de contrato, as primeiras fontes de obrigações na definição de Gaio. ${ }^{55}$

Assim, a primeira forma das obrigações seria aquela que deriva de um ato ilícito, ou seja, de um ato de violência material perpetrado por um indivíduo pertencente a um agrupamento gentílico contra outro. Ato este que provocaria a vingança por parte do grupo ofendido, vingança limitada, mais tarde, pela intervenção dos órgãos da civitas, ao talião, depois, à transação pecuniária, inicialmente voluntária, mas logo imposta coativamente.

Esta situação de vingança inicial teria sido o berço das obrigações contratuais.

Segundo Arangio-Ruiz, a obrigação, originalmente, revestia-se, no direito romano, de um caráter fortemente personalista. Em sua concepção primitiva, as pessoas do credor e do devedor eram seus elementos integrantes, idéia que decorre da sujeição pessoal do obrigado ao poder do credor, ${ }^{56}$ sendo impossível, sem que se atacasse um dos seus elementos essenciais, operar-se a sucessão singular nas obrigações.

Não se encontra naquele direito a moderna noção de crédito, nas obrigações somente se concebiam as pessoas obrigadas, os condenados judicialmente, os delinqüentes e aqueles sujeitos à prisão por dívida, sendo absolutamente estranha a idéia do crédito como coisa incorpórea.

De acordo com os princípios consubstanciados na lei das XII Tábuas, a noção subjetiva do crédito era desconhecida no antigo direito. Não havia, ainda, a concepção do crédito como coisa incorpórea. Conceituavam-se as coisas corpóreas (res) e os sujeitos de direito (personae).

Havia pessoas obrigadas, isto é, vinculadas a um compromisso, como os judicati, os delinqüentes e os nexi. Judicati eram os condenados judicialmente, os delinqüentes podiam ser obrigados a reparar os danos causados às vítimas. Sobre os nexi há numerosas teorias que serão

\footnotetext{
55 “Agora passemos às obrigações, cuja principal divisão é a que as distingue em duas espécies, porque toda obrigação nasce ou de um contrato ou de um delito" (Institutas do Jurisconsulto Gaio, III, 3, 88. Tradução de CRETELLA Jr., José, e CRETELLA, Agnes. São Paulo: RT, 2004, p. 149).

${ }^{56}$ ARANGIO-RUIZ, Vicenzo. Instituzioni di Diritto Romano. Napoli: Casa Editrice Dott. Eugenio Jovene, $14^{\mathrm{a}}$ ed., 2006, p. 317-318.
} 
estudadas oportunamente, bastando salientar desde logo deverem ser assim consideradas as pessoas sujeitas à prisão por dívidas. ${ }^{57}$

Para outros romanistas teria sido o contrato a forma mais antiga de obrigação e de sua concepção teria evoluído a idéia de delito, na medida em que impõe ao ofensor o pagamento de uma soma em dinheiro. ${ }^{58}$

Sobre outras tantas propostas acerca da origem da obrigação romana tem influído, ainda, a teoria proposta por Brinz, forma de explicar alguns institutos vigentes nos direitos nórdicos antigos, logo utilizada como fórmula explicativa dos demais direitos arcaicos e mesmo modernos. Baseia-se ela sobre a distinção de dois elementos no vínculo obrigacional: o primeiro, Shuld, é o dever do sujeito passivo de realizar a prestação, o segundo, a responsabilidade pessoal que sobre ele pesa pela prestação devida (Haftung), caminhando, portanto, para considerar o objeto da obrigação como sendo a pessoa do devedor, não propriamente a prestação devida. ${ }^{59}$

Esta ultima opinião tem sido defendida por diversos romanistas, que consideram o nexum não só como a mais antiga forma de obrigar-se, mas também como forma do devedor submeter sua pessoa ao poder direto do credor como garantia do cumprimento de uma dívida, ponto de vista corroborado, de certa forma, pela sistemática do processo executivo arcaico.

No período das legis actionem, a execução fazia-se diretamente contra a pessoa do devedor. Uma vez iniciada a execução, abria-se prazo de trinta dias para que o devedor pagasse seus débitos, passados os quais, se ainda inadimplente, seria diretamente entregue ao credor para que este, no prazo de sessenta dias, por três vezes o levasse às feiras da cidade, apregoando seu crédito. Se ainda assim os débitos não fossem satisfeitos, o credor era autorizado a tomar a vida do devedor ou a vendê-lo trans tiberim. ${ }^{60}$

É somente mais tarde que a lei das XII Tábuas reduziu a aplicação da manus injectio apenas aos casos de condenação ou confissão de dívida, conforme se depreende do texto da tábua III:

Aquele que confessa a dívida perante o magistrado ou é condenado, terá trinta dias para pagar.

Esgotados os trinta dias e não tendo pago, que seja agarrado e levado à presença do magistrado.

\footnotetext{
${ }^{57}$ MEIRA, Sílvio A. B. op. cit., p. 307-308.

${ }^{58}$ VOLTERRA, Eduardo. op. cit., p. 451.

${ }^{59}$ VOLTERRA, Eduardo. op. cit., p. 451.

${ }^{60}$ BUZAID, Alfredo. Do Concurso de Credores no Processo de Execução. São Paulo: Saraiva, 1952, p. 43-44.
} 
Se não paga e ninguém se apresenta como fiador, que o devedor seja levado pelo seu credor e amarrado pelo pescoço e pés com cadeias de peso até o máximo de quinze libras; ou menos, se assim o quiser o credor.

$\mathrm{O}$ devedor preso viverá à sua custa, se quiser; se não quiser, o credor que o mantém preso dar-lhe-á por dia uma libra de pão ou mais, a seu critério.

Se não há conciliação, que o devedor fique preso por sessenta dias, durante os quais será conduzido em três dias de feira ao comitium, onde se proclamará em altas vozes o valor da dívida.

Se são muitos os credores, é permitido, depois do terceiro dia de feira, dividir o corpo do devedor em tantos pedaços quantos sejam os credores, não importando cortar mais ou menos; se os credores preferirem, poderão vender o devedor a um estrangeiro além do Tibre. ${ }^{61}$

Embora a Lex Poetelia Papiria, em 428 ou 441 (não se sabe ao certo a data de sua elaboração), tenha reduzido as hipóteses de incidência da manus injectio à confissão de dívida perante o magistrado ou a execução de condenação judicial - ampliava-se, neste momento, os poderes de intervenção do juiz, reduzindo-se a possibilidade de exercício da vingança privada, ${ }^{62}$ gradativa mudança do caráter de sujeição física do devedor, para o da jurídica -, nem por isso a obrigação no direito romano perdeu seu caráter eminentemente pessoal.

Alguns romanistas pretenderam, por outro lado, encontrar na legis actio per sacramento a mais antiga forma de expressão do direito das obrigações, sendo, em lugar da sujeição pessoal do devedor, que só mais tarde se verificaria, a sujeição da pessoa daqueles que garantiam a dívida (praetes). ${ }^{63}$

Entretanto, não se pode ter certeza que a condição de sujeição material da pessoa do devedor ou de um garante, abolidas pela Lex Poetelia Papiria uma conseqüência do vínculo obrigacional ou somente um efeito do sistema de execução das sentenças no processo civil romano, o que tornaria pouca verossímil a descrição das obrigações com base nos efeitos do processo executivo instaurado por inadimplemento.

Em todo caso, partindo-se do pressuposto de distinção entre dívida e responsabilidade, a doutrina romanística atual, ligada ao movimento de reconstrução histórica do Direito Romano, considera que, de um lado não existiria, para o povo romano, um conceito abstrato de obrigação como vínculo que compromete uma pessoa a um determinado comportamento, por outro lado, haveria a situação de sujeição física do

\footnotetext{
${ }^{61}$ MEIRA, Sílvio A. B. A Lei das XII Tábuas. Rio de Janeiro: Forense, 1961, p. 170.

${ }^{62}$ BUZAID, Alfredo. op. cit., p. 52.

${ }^{63}$ VOLTERRA, Eduardo. op. cit., p. 452.
} 
devedor ao poder do credor, idéia formada mesmo antes da constituição da civitas romana. $^{64}$

Esse quadro que se vem de delinear, diante da multiplicidade e variedade das hipóteses teóricas apresentadas acerca do surgimento das obrigações em Roma, serve para demonstrar, num primeiro momento, a complexidade e dificuldade de se enfrentar o problema, num segundo, que não se pode encontrar bases seguras nas fontes romanas para se formular uma hipótese definitiva, o que certamente pode afastar a ideia de que nesse período inicial do direito romano se tenha aventado qualquer sistema de classificação que se assemelho ao que ora se põe em estudo.

Em meados do século II, a lei Aebutia substitui o sistema do procedimento formulário e ao mesmo tempo, a sociedade romana evolui.

Roma submete a seu comando todo o mundo mediterrâneo e, ao mesmo tempo, abre-se às influências externas dos povos grego e egípcio. O direito da cidade já não é capaz de satisfazer as exigência dessa expansão. As relações se desenvolvem, a economia se transforma e o comércio toma a importância antes sentida na agricultura.

Nesse quadro, o direito romano antigo, carregado de traços mais grosseiros, é submetido à equidade, vale dizer, ao princípio do dar a cada um o que é seu (cuum cuique tribuere).

Contudo, sob o alto império, o direito privado romano aparece como um sistema individualista, enquanto que do ponto de vista político, a liberdade dos cidadãos romanos diminui sem cessar. A submissão absoluta ao imperador opõe-se à grande liberdade dos cidadãos de disporem de seus bens a título privado, o que leva os juristas clássicos a elaborarem um sistema bastante mais coerente e completo. ${ }^{65}$

$\mathrm{Na}$ época clássica e já tardo republicana, o devedor de executar sua prestação e passa a responder ao credor por meio de ações pessoais em caso de inadimplemento.

Essa responsabilidade apresenta, nesse momento, caracteres particulares, afastou-se ao menos em parte, a natureza pessoal do objeto da prestação encontrado no direito clássico, embora a execução contra a pessoa do devedor continue sendo possível, pois no processo formulário, o juiz pode proferir uma condenação de pagar a litis aestimatio, valoração em termos pecuniários do interesse do credor frustrado pelo inadimplemento. ${ }^{66}$

\footnotetext{
${ }^{64}$ VOLTERRA, Eduardo. op. cit., p. 452.

${ }^{65}$ GILISSEM, John. op. cit., p. 87.

${ }^{66}$ TALAMANCA, Mario. Istituzioni di Diritto Romano. Milano: Giuffrè, 1990, p. 502.
} 
A despeito da superação da vinculação física do devedor às suas obrigações, ainda fazia-se sentir o gravíssimo formalismo que as ações da lei impunham ao processo, vez que qualquer alteração dos ritos previstos impunha a improcedência da ação. Por isso é que antes do fim da República a este sistema veio juntar-se o formulário, ${ }^{67}$ que importava na entrega de pelo magistrado de uma fórmula às partes, sem nenhuma formalidade prévia, para que então a apresentassem ao juiz.

Durante o período das ações da lei, em que a intentio e a condemnatio eram certas, os juízos eram de direito estrito, cabendo ao juiz tão somente declarar o direito e determinar a devolução da coisa reclamada por meio do rito, contudo, já no período formulário, grande parte das ações era julgada pelo sistema do arbitrium, que autorizava o julgador a apreciar não só a natureza do direito discutido, mas também a extensão da condenação pleiteada. Neste quadro, tratando-se o caso de litígio fundado em contrato, dizia-se que o julgamento deveria fazer-se segundo a boa-fé, pelo que a designação de tais ações formulárias era bonae fidei actiones. ${ }^{68}$

Ainda assim, é de se considerar que as obrigações permanecem típicas, o que se pode sentir na terminologia utilização na indicação do sujeito passivo, reus para a stipulatio, creditore para as obrigações que importam e um credere, entre outros. Contudo, gradativamente, à medida em que os limites do instituto se alargam, vai se formando uma doutrina comum a todas as obrigações, que coexiste com o regime próprio de cada uma delas em especial, os termo credor e devedor, para designar o sujeito ativo e passivo, tornam-se mais comuns sem que se exclua, qual na linguagem do direito moderno, a classificação própria a cada um dos vínculos analisado (comprador e vendedor, mutuante e mutuário, etc.). ${ }^{69}$

Não é por outro motivo que podemos encontrar nas fontes duas definições de obligatio, ao fim consideradas substancialmente genuínas, em que pesem as críticas acerca da existência de interpolações. ${ }^{70}$

${ }^{67}$ PETIT, Eugène. Tratado Elementar de Direito Romano. trad. Jorge Luís Custódio Porto, Campinas: Russel, 2003, p. 833.

${ }^{68}$ MAYNS, Charles. Cours de Droit Romain. Bruxelas: Bruylant-Christophe, 1877, v. 2, p. 133.

${ }^{69}$ BIONDI, Biondo. Istituzioni di Diritto Romano. Milano: Giuffrè, 1972, p. 343.

${ }^{70}$ Belíssima crítica a um definição geral de obrigações no direito romano clássico, especialmente diante das interpolações, é a apresentada por Emilio Albertario, que concluir que as fontes de obrigações romanas delictum e contractus - não eram categorias gerais, ou seja, não se reconhecia o contrato como espécie de negócio jurídico e, tampouco, o delito como ato ilícito que impusesse a reparação. As obrigações nasciam, em Roma, das diversas figuras típicas (contratos e delitos) previstas expressamente naquele direito (ALBERTARIO, Emilio. Le definizione dell'obbligazioni romana. in Studi di Diritto Romano. Milano: Giuffrè, 1936, v. 3, p. 4). 
A primeira, obligatio est iuris vinculum, quo necessitate adstringemur alicuis solvendae rei secundum nostrae civitatis iura (obrigação é um vínculo jurídico com base no qual se é obrigado a prestar uma coisa com base no direito da cidade), a segunda, de Paolo, D. 44.7.3 pr., obligationum sbstantia non in eo consistit, ut aliquod corpus nostrum aut servitutem mostram faciat, sed ut alium nobis obstringat ad dandum vel faciendum vel paestandum (a essência da obrigação não se encontra na circunstância de sermos titulares de um direito de propriedade ou servidão, mas sim no vínculo segundo o qual se pode exigir uma prestação in dando, in faciendo in praestando ${ }^{71}$

Nessa evolução, entretanto, não se conclui uma construção de uma teoria geral das obrigações, o que igualmente se pode dizer dos contratos, faltando igualmente para estes essa abordagem geral, posto que mantidas as figuras específicas que fazem surgir obrigação. Isso pois o contrato é de ser entendido, nesse direito, como um negotium contrahere, ou seja no contractus emerge o conceito de negotium ao lado do vínculo que se contrai e especificamente como capaz de produzir um vínculo obrigacional. Entretanto, cabe aqui pontuar que negotium não quer guardar qualquer relação com o que se compreende hoje como negócio jurídico, trata-se antes de uma referências às trocas, às relações negociais como se desenrolam no mundo, o movimento entre prestações que saem e entram de um patrimônio em outro. ${ }^{72}$

A falta de um teoria geral das obrigações e dos contratos, e mesmo de suas conceituações gerais nos parece suficiente para concluir que não seria possível encontrar, no direito romano, raízes para a distinção das obrigações segundo seu conteúdo, ainda assim e exatamente por isso que diversos autores acreditam referências à classificação ora em exame em espécies determinadas.

Assim é que o relevo da distinção das obrigações de meios e de resultado, na experiência romana, encontra-se, em larga medida, ligada à controvérsia reinante acerca da tripartição da locatio-conductio segundo seu objeto, rei, operis, operarum.

De fato, a alternativa locatio operis e locatio operarum constitui-se no modelo mais nítido de uma contraposição entre o dever de um resultado (opus) e a obrigação de meios (operae) para os doutrinadores que defendem a tripartição como tendo origem romana. ${ }^{73}$

Segundo opinião recentemente difundida entre os doutrinadores, o direito romano não conheceu as três espécies individuais que a doutrina medieval e moderna encontram na

\footnotetext{
${ }^{71}$ TALAMANCA, Mario. op. cit., p. 503.

${ }^{72}$ GOGLIANO, Daisy. Tratativas Pré-contratuais (bases de uma teoria). op cit., p. 31 e ss.

${ }^{73}$ CARBONE, Enrico. op. cit., p. 15
} 
locatio-dondcutio. Diversamente, um conceito unitário de locação, que correspondia à unidade da terminologia que se encontra nas fontes, fundava-se na circunstância de que o locador coloca, de modo definitivo, à disposição do conductor uma coisa, que este último deve restituir após ter dela fruído temporariamente. Esse trato unitário, de fácil conciliação com a locatio rei e da locatio operis, funcionaria igualmente para os casos de locatio operarum, caso em que a "coisa" colocada à disposição do locador haveria de identificar-se com a pessoa prestadora do serviço, em que pese não ser ela res verdadeiramente. $^{74}$ Desta forma, não poderia deixar de ser efetivamente moderna a classificação das obrigações segundo seu conteúdo.

Em que pese não se encontrar na locatio-conductio o germe da distinção das obrigações segundo seu conteúdo, muitos autores crêem poder encontra-la inserida na responsabilidade pela custódia da coisa, envolvendo-se na discussão acerca da evolução da custódia clássica - critério de responsabilidade objetiva - e custódia pós-clássica - base de uma responsabilidade subjetivamente considerada, no sentido de que impõe ao devedor o dever de diligentia in custodiendo.

Que o receptum nautarum cauponum stabulariorum da lugar a uma responsabilidade particularmente rigorosa no direito romano é incontestável.

O direito romano concebeu os meios mais variados para a responsabilização daqueles que recebessem a coisa para guarda, além da ação contratual, derivada da locação-condução que se restringe às partes contratantes, oferecia-se uma ação penal de dano e uma de furto, respeitante ao dono de embarcação, ao dono de albergue e ao estalajadeiro até pelos danos e furtos perpetrados pelas pessoas que deles dependiam, por fim, uma clausula especial do édito de receptis, que determinava que aquele que recebera a coisa ser chamado a responder em via contratual pelos danos ou furtos que ocorressem em seus barcos, albergue ou estalagens. ${ }^{75}$ Essa responsabilidade, chamada de per custodia, estende-se a todos aqueles sujeitos que, ainda que não tenham se tornado expressamente depositários da coisa, recebem-na a fim de que possam realizar seu mister ou atividade (lavanderias, costureiros, etc.), já que custodia nominem tenetur. ${ }^{76}$

Trata-se de responsabilidade essencialmente objetiva pela falta de devolução da coisa entregue e que surgia de maneira independente daquela fundada sobre $o$

\footnotetext{
74 TALAMANCA, Mario. op. cit., p. 593.

${ }^{75}$ ARANGIO-RUIZ, Vincenzo. op. cit., p. 103.

${ }^{76}$ D'AMICO, Giovanni. op. cit., p. 15.
} 
descumprimento do contrato primário (entrega para lavagem ou restauração de tecidos, etc.), esta ainda sim baseada na culpa.

Desta forma, abriam-se dois caminhos diversos para o credor, a propositura da actio ex recepto, dominada pela responsabilidade objetiva, ou da ação fundada sob o contrato não cumprido, onde haveria de ser demonstrada a culpa. ${ }^{77}$

No direito pós-clássico, as hipóteses até então prevista para a custódia continuaram a ser de responsabilidade objetiva, entretanto, o início da sistematização da responsabilidade contratual no direito bizantino, fundada na culpa, para criar situações anacrónicas naquele antigo sistema de responsabilização do devedor. É o caso, por exemplo, do comodatário, uma das hipóteses de responsabilidade pela custódia, passa a ser considerado devedor de uma exatíssima diligência, limitando-se sua responsabilidade à verificação dos casos fortuitos ou de força maior. ${ }^{78}$

Embora nesse ponto possa-se dizer que o direito pós-clássico caminha para a criação de uma responsabilidade subjetiva, caracteriza pelo dever de custódia, não é demais lembrar que a timidez com que se faz a distinção, restrita aos casos de força maior ou caso fortuito na responsabilidade ex recepto, para sinalizar para o fato inegável de que pretendia-se, senão substancialmente, ao menos formalmente manter o caráter objetivo da obrigação de custódia. ${ }^{79}$

O que nos leva a crer que diante das constantes interpolações, tornando pouco confiáveis as fontes da época, seria demasiado arriscado procurar encontrar na responsabilidade pela custódia as origens da distinção das obrigações de meios e de resultado.

Aliás, não é demais lembrar que na época pós-clássica, em que pese a distinção entre ius civile e ius honorarium suprimir-se, inexistia ainda uma teoria geral das obrigações, o que quer nos parecer que razão suficiente para impedir a articulação e o surgimento de uma divisão das obrigações segundo seu conteúdo (obrigações de meios e de resultado) além dos limites particulares de cada uma das figuras típicas.

\footnotetext{
${ }^{77}$ D’AMICO, Giovanni. op. et loc. cit.

${ }^{78}$ ARANGIO-RUIZ, Vincenzo. op. cit., p. 68.

${ }^{79}$ D'AMICO, Giovanni. op. cit., p. 24
} 


\subsection{ORIGENS DA DISTINÇÃO.}

A René Demogue, comumente, é atribuída a paternidade da classificação das obrigações em duas categorias, as de "meio" e as de "resultado", no entanto, mais preciso seria comemorar o fato de ter sido o seu Traité des obligations en Géneral ${ }^{80}$ o responsável por sobre ela lançar, verdadeiramente, a atenção do mundo jurídico, pois, como se verá, a doutrina alemã dela já tratou em 1889, de onde passou à Itália, enunciando-se no pensamente de Francesco Leone em 1915 e, três anos mais tarde, no de Giuseppe Osti.

Diversos autores, no entanto, tendo considerado a proposta teórica de classificação das obrigações segundo seu objeto a simples constatação da verdadeira natureza das obrigações, passaram a procurar suas origens históricas em momento bem anterior ao de sua formulação. ${ }^{81}$

Isso certamente explica a proposta de Henri Mazeud de que ela teria sido intuída antes mesmo da codificação napoleônica.

Segundo esse autor os juristas anteriores ao Code Civil, em função da análise da intenção das partes contratantes, teriam percebido que nos casos em que o devedor se obrigara estritamente a um determinado comportamento seria suficiente constatar a inexecução de sua prestação para que sobre ele se impusesse o dever de indenizar, enquanto que se tivesse ele se obrigado a agir diligentemente, vale dizer, sem culpa, seria imperativo, para a sua responsabilização que se fizesse uma análise extensa de sua conduta. $^{82}$

A síntese deste pensamento poderia ser encontrada na obra de Domat em duas passagens, a primeira afirma que:

desde que não haja nem intenção de lesar nem má-fé no ato causador do dano, deve-se ponderar se o dano adveio de qualquer negligência ou culpa, ou sem que nada pudesse ser imputado àquele que alega tê-lo sofrido. Assim, por exemplo, se aquele que alugou um cavalo, servindo-se dele em noite escura, em lugar pedregoso, rico em perigosos caminhos, o cavalo se estropia, ou se, por culpa sua, ele é roubado, poderiam ser-lhe imputadas tais faltas. Mas se, sem culpa sua, o cavalo se estropia, ou se o cavalo é roubado em pleno dia em uma avenida, o

\footnotetext{
${ }^{80}$ DEMOGUE, René. op. cit., t. V, p. 536 e ss.

81 "L'idée était en puissance déjà dans le droit romain, et un grand nombre d'auteurs, tant dans notre ancien droit que depuis la rédaction du Code Civil, en ont eu au moins l'intuition" (MAZEUD, Henri. op. cit., p. 25). Neste mesmo sentido Joseph Frossard (La distinction des obligations de moyens et des obligations de résultat. Paris: LGDJ, 1965, n. 20 e ss.

${ }^{82}$ MAZEUD, Henri. op. cit., p. 27.
} 
a segunda nos diz que:

proprietário do cavalo suportará sua perda. Pois estes são os casos fortuitos que sobre ele recaem (tradução livre) ${ }^{83}$

ainda que não exista qualquer culpa daquele de quem se demanda reparação, isso nem sempre é suficiente para liberá-lo. Pois casos há em que são devidas perdas e danos sem que haja qualquer culpa, mas por simples efeito de um contrato. Assim, quem vendeu de boa-fé coisa que acreditava ser sua é obrigado fazer cessar qualquer pretensão daquele que se pretende seu proprietário e, se é vencido, tornar-se-á devedor das perdas e danos decorrentes da evicção, ainda que não haja má-fé de sua parte, tampouco qualquer outra espécie de culpa; desta forma, aquele que deixa de entregar aquilo que vendeu obriga-se pelas perdas e danos decorrentes da falta de sua entrega; e tais perdas e danos são mera decorrência das obrigações daquele que vende (tradução livre). ${ }^{84}$

É bem dizer, contudo, que Domat, naquele ponto, preocupava-se em precisar as circunstâncias que imporiam o dever de reparar, ainda que pudesse ele surgir da pura e simples inexecução involuntária da prestação devida. ${ }^{85}$

O pensamento jurídico de sua época, cumpre lembrar, prendeu-se a uma filosofia dominada pelas regras morais, herança da literatura e filosofia religiosas do medievo, pelo que a culpa ganhou o papel de fundamental sustentáculo da responsabilidade civil.

Passadas as invasões bárbaras, a cultura romana, malgrado as tentativas de sua restauração, entrou em franco e irreparável declínio, surgindo em seu lugar um pensamento religioso preocupado em pregar a obediência a uma moral divina, que, mais tarde dessacralizada e tornando-se filosófica, "sob o nome de primado da 'lei natural', junto à

\footnotetext{
83 "Lors qu'il n'y a ny dessein de nuire, ny mauvaise foy dans le fait qui a causé le dommage, il faut encore considérer, si le dommage est arrivé par quelque negligence, ou par quelque faute, ou fans que rien puisse être imputé à celuy qu'on prétend en être tenu. Ainsi, par exemple, si celuy qui a pris un cheval de louage, s'en servant pendant une nuit obseure, dans Un lieu pierreux plein de mauvais pas, le cheval s'estropie, ou faute de soin il lui est dérobé, on pourra lui imputer ces sortes de fautes. Mais si sens sa faute le cheval s'estropie, ou s'il est volé en plein jour dans un grand chemin, le maître du cheval en portera la perte. Car ce sont des cas fortuits qui tombent sor lui" (DOMAT, Jean. Les Loix Civiles dans leur ordre naturel. Paris: Pierre Aubouin, Pierre Emery et Charles Clouzier, $2^{\text {a }}$ ed., 1697, t. II, p. 329).

84 "Quoyqu'il n'y ait aucune faute de la part de celui à qui on demande um dédommagement, ce n'est pas toûjours assez pour l'en décharger. Car il y a des cas où est dû des dommages \& intérêts, sans qu'aucune faute y ait a donné lieu; mais par le simple effet d'un engagement. Ainsi, celuiqui avoit vendu de bonne foy une chose qu'il croyoit sienne, est obligé dé faire cesser la demande de celui qui s'en prétend le maître, \& s'il y manque, il devra les dommages \& intérêts del'éviction, quoy qu'il n'y ait de sa part aucune mauvaise foy, ni aucune autre espece de faute, ainsi celui qui manque de délivrer ce qu'il a vendu est ténu des dommages \& interêts qui suivent du défaut dela délivrance. et ces dommages \& intérêts sont de simples suites des engagemens de celui qui vénd" (DOMAT, Jean. op. cit., t. II, p. 329-330).

85 "Aprés cette distinction des Intérêts, \& des dommages \& interêts, il faut remarquer sur les dommages \& intérêts, que c'est par deux vîës qu'on peut juger s'il en est dî; \& qu'on doit les régler. Car on doit premièrement considérer la qualité du fait d'où le dommage est arrivé, comme si c'est un crime, un délit, une tromperie: Où si c'est seulement quelque faute, quelque négligence, ou l'inexécution involontaire d'un engagement. Car selon ces différences les dédommagemens peuvent, être ou plus grands ou moindres, comme on le verra dans la suite. Et on doit aussi considérer les évenémens qui ont suivy ce fait, \& s'ils sont tels qu'on doive les imputer à celuy qui en est d'auteur, ou s'il s'y trouve d'autres causes jointes, \& que toutes ces suites ne doivent pás luy être imputées" (DOMAT, Jean. op. cit., t. II, p. 297).
} 
consciência ou à 'Razão', específica da 'natureza humana', o que permitiu o estoicismo ou epicurismo. Ela estenderá seus tentáculos até as obras de direito", ${ }^{86}$

Assim o direito civil dos modernos, refundado como um prolongamento da moral, veio a adotar a regra segundo a qual a culpa seria o sustentáculo principal da responsabilidade, regra esta "muito presente nas Sumas dos confessores, na moral de São Tomás, nos escolásticos espanhóis e nos professores de moral do século XVII: cada um de nós será obrigado, se faz mal ao próximo, de 'restituire', de repor as coisas no lugar, de "reparar todos os danos causados por culpa", 87

A preocupação com a conduta respeitante à moral não só é capaz de se explicar a preocupação de Domat com a culpabilidade, pressuposto da responsabilidade civil, como também a sua conclusão de que o vendedor responderia pela evicção ainda que para ela não houvesse concorrido culposamente, afastando qualquer idéia de que a isso tenha chegado aquele autor em razão de uma diferença de conteúdo e extensão entre as obrigações.

Isso porque, segundo o antigo autor francês, todas as convenções fariam surgir, no ato de sua formação, bem como em sua execução, os deveres atinentes à boa fé e à equidade, o que, na compra e venda significaria que "o vendedor é obrigado a entregar a coisa vendida: a conservá-la até a sua entrega: a garanti-la e: a retomá-la se ela tiver defeitos, ainda que sejam aquelas que imponham a sua resolução" (tradução livre). ${ }^{88}$

Nestes termos é que se pode dizer que todas as convenções são fonte de três ordens de obrigações: a primeira, das livremente pactuadas, a segunda, das oriundas da própria natureza do pacto firmado e, finalmente, a terceira, daquelas impostas pela equidade, pela lei, ou pelos costumes, ${ }^{89}$ o que igualmente se aplica ao contrato de compra e venda. ${ }^{90}$

Nesse quadro, a obrigação do vendedor de ressarcir os danos causados pela evicção da coisa é a ele imposta pela própria natureza do contrato de compra e venda firmado e independe de sua expressa previsão pelas partes contratantes.

\footnotetext{
${ }^{86}$ VILLEY, Michel. Esboço Histórico sobre o termo responsável. Tradução de CORRÊA, André Rodrigues. Revista de Direito GV, São Paulo, v. 1, n. 1, p. 141-142, maio 2005.

${ }^{87}$ VILLEY, Michel. op. cit., p. 144.

88 "le vendeur est obligé à délivrer la chose vendue: a la garder, jusqu'à la délivrance: a la garentir et: a la reprendre, si elle a des défauts, qui soient tels que la vente doive être résolue"( DOMAT, Jean. op. cit., t. I, p. 85).

${ }^{89}$ DOMAT, Jean. op. cit., t. I, p. 78-79.

${ }^{90}$ DOMAT, Jean. op. cit., t. I, p. 112.
} 
Trata-se, portanto, de garantia legal e não convencional, ${ }^{91}$ no que significaria a aplicação da boa-fé e da equidade, afastando do comprador de boa-fé a possibilidade de sofrer quaisquer prejuízos.

Isso, segundo nos parece, explica a afirmação de Domat de que a obrigação de reparar venha a existir "ainda que não haja má-fé de sua parte (vendedor), tampouco qualquer outra espécie de falta" nos casos de evicção. Pois, se de uma lado a responsabilidade civil surgiria sempre que um ato danoso fosse praticado com o concorrência de culpa, por outro, certos contratos, por força da boa-fé, imporiam por si mesmos a obrigação de reparar (garantia).

Não há, portanto, segundo seu pensamento, distinção entre as obrigações segundo seu o seu conteúdo (obrigações de meio e de resultado), já que a um só tempo, o dever de se conduzir de maneira honesta e escorreita, em atenção à moral, de um lado imporia o dever de reparar os danos causados com culpa (responsabilidade civil) e, de outro, a obrigação de garantia imposta a uma das partes por força da boa-fé.

Assim, não se há de dizer que que tenham, efetivamente, os juristas anteriores ao Code Napoléon intuído serem diversas as obrigações fruto da promessa do devedor de realização de um ato determinado (obrigação de resultado) daquelas por força das quais se obrigava ele a conduzir-se com prudência em vista de um objetivo previamente acordado (obrigação de meio).

Com o advento dos movimentos de codificação e embora o Code a tenha ignorado, a questão parece ter se tornado mais próxima da pena de diversos autores no centenário que a ela se seguiu. ${ }^{92}$

Glasson teria a ela feito referência em sua obra Le Code Civil et la question ouvirère quando se reportou às "obrigações de dar ou de fazer" e às "obrigações de precaução" ou de "diligência", 93 e mais tarde, em 1887, a questão teria se encontrado na tese de doutorado de Georges Robin intitulada Responsabilité notamment au point de vue de la clause de non garantie et du fardeau de la preuve en droit romain et en droit français, ${ }^{94} \mathrm{e}$, ao menos "em estado latente", 95 no artigo de autoria de Marcel Paniol publicado na Revue Critique de Legislation et Jurisprudence do ano de 1888.

\footnotetext{
${ }^{91}$ DOMAT, Jean. op. cit., t. I, p. 154.

92 BELISSENT, Jean. Contribution à l'analyse de La distinction des obligations de moyens et des obligations de résultat à propos de l'évolution des ordres de responsabilité civile. Paris: L.G.D.J, 2001, p. 16.

${ }_{93}$ MAZEUD, Henri. op. cit., p. 29.

${ }^{94}$ ROBIN. Georges. Responsabilité notamment au point de vue de la clause de non garantie et du fardeau de la preuve en droit romain et en droit français. Paris: Imprimerie E. Pigelet, 1887.
} 
A análise da obra de Robin nos mostra, em seu primeiro capítulo, que o autor preocupou-se em apresentar uma breve análise dos princípios norteadores da responsabilidade civil no direito romano, tendo, diante dos preceitos encontrados, concluído que a idéia de culpabilidade era pressuposto necessário da responsabilização naquele direito.

Além disso, ainda naquele momento considera o autor que as situações que faziam surgir a obrigação de reparar sem que, para tanto, existisse culpa do obrigado, como nos casos de perda da coisa por caso fortuito, tratavam-se, na verdade, de obrigações condicionais, casos em que uma das partes se obrigara frente a outra a pagar o correspondente em moeda, vindo a coisa a perecer.

Assim é que baseado naquele pressuposto comum de toda responsabilidade civil (existência de culpa ou dolo) e nas consequiências idênticas que a quebra de obrigações impostas por normas contratuais ou legais ocasiona, pode considerar indivisível, ao menos segundo sua fonte (a contratual ou legal), a responsabilidade civil no direito romano. ${ }^{96} 97$

Não é, no entanto, para esse ponto que Van Ryn e Mazeud chamam a atenção. A grande importância da tese de Robin residiria em sua análise da distribuição do ônus probatório no direito romano, que o teria levado, segundo eles, a vislumbrar a distinção das obrigações de resultado e de meio.

Os juristas romanos, segundo parece a Robin, teriam pouco se preocupado com a formulação de regras específicas atinentes à distribuição do ônus probatório. Até porque, uma vez entregue do pretor ao juiz a fórmula que deveria nortear seu julgamento, a adequada instrução do processo e a formação de seu convencimento restariam a seu cargo, conduzindo-se o julgador segundo o bom senso. ${ }^{98}$

Assim, na falta de preceitos específicos, seriam aplicáveis às causas de responsabilidade civil os princípios gerais em matéria de prova, quais sejam, (i) ao autor incumbiria a prova dos fatos constitutivos de seu direito e (ii), ao réu, tendo aquele se desincumbido de tal ônus, o de provar os fatos extintivos ou modificativos. ${ }^{99}$ Regras que

\footnotetext{
${ }^{95}$ RYN, Jean Van. Responsabilité aquiliènne et contrat en droit positif. Paris: Sirey, 1932, p. 18.

${ }^{96}$ ROBIN. Georges. op. cit., p. 13-25.

97 É de se notar, no entanto, que este critério comum encontrado por Robin, o elemento subjetivo na responsabilidade contratual, não se encontrava no direito, a sua redução ao dolo e à culpa, dos quais seria conseqüência o inadimplemento, é generalização teórica que somente veio a ocorrer no direito medieval. Na verdade o direito romano clássico somente estabelecia critérios casuísticos para a configuração da responsabilidade por descumprimento contratual (ARANGIO-RUIZ, Vincenzo. Istituzioni di Diritto Romano. Napoli: Casa Editrice Dott. Eugenio Jovene, 2006, p. 381).

${ }^{98}$ ROBIN. Georges. op. cit., p. 47-48.

${ }^{99}$ ROBIN. Georges. op. cit., p. 50-52.
} 
teriam, ainda, incidência sobre todas as demandas de responsabilização civil, não sendo possível falar-se em inversão do ônus probatório nos casos de responsabilidade civil contratual.

Robin afirma, ainda, que nem todas as demandas fundadas em obrigações contratuais efetivamente tratariam de responsabilidade civil, não sendo possível, em todos os casos, discutir-se a intenção do devedor na pratica do ato a ele imputado. Ou seja, para o autor, a reclamação da prestação não entregue, por exemplo o escravo prometido, não seria efetivamente uma demanda de reparação civil de danos causados, obrigação secundaria decorrente do descumprimento de obrigação imposta pela lei ou por contrato, mas sim e tão-somente a execução forçada daquela obrigação primária, daquela prestação inicialmente prometida. $^{100}$

Nesse ponto é que o autor vai tocar a distinção ora em análise:

[...] a idéia de culpa não deve intervir senão de uma maneira negativa, no sentido de que se o caso fortuito ou de força maior que me impediu de cumprir minha obrigação, serei dela liberado.

Isso não é mais que um efeito, considera-se que eu tenha prometido não um resultado, mas um esforço constante e sincero; se, quando eu tenha realizado tal esforço, um golpe do destino impediu o resultado, a mim não se deve impor nenhuma responsabilidade. Além disso, àquele a quem eu tenha prometido a entrega de um escravo não se impõe tenha de provar senão uma única coisa, a saber, que eu tenha the prometido aquele escravo, e ele não é obrigado de maneira nenhuma a provar que eu tenha agido com culpa ao não entregá-lo. Não há necessidade de se falar em culpa, pois ele não intentou uma ação de responsabilidade, ele não fez outra coisa se não demandar o cumprimento de uma obrigação inicial que nasceu apenas por força do contrato (tradução livre) ${ }^{101}$

para concluir, por fim, que:

o contrato habitualmente comporta, deste modo, duas causas de obrigações, uma, inicial e formal, diga-se a a prestação que ele constitui, o objeto mesmo do contrato, a outra, virtual e condicional donde o objeto é a reparação do prejuízo causado pela inexecução da primeira. Nós vimos que em alguns casos especiais não encontramos senão a primeira obrigação, nos citamos neste sentido o contrato segundo o qual nos obrigamos a assumir o risco do caso fortuito. Inversamente, em outras

\footnotetext{
${ }^{100}$ ROBIN. Georges. op. cit., p. 55.

101 "[...] L'idée de faute n'a à intervenir que d'une façon toute négative en ce sens que, si c'est un cas fortuit ou de force majeure qui m'a empêché d'exécuter mon obligation, je serai libéré.

$C^{\prime} e s t$ qu'en effet, je suis réputé avoir promis non pas un résultat, mais un effort constant et sincère; si, quand j'ai accompli cet effort, un coup du hasard a empêché le résultat, je ne dois encourir aucune responsabilité. Mais, celui à qui j'ai promis un esclave n'est tenu de prouver qu'une seule chose, à savoir que je lui ai promis cet esclave, et il n'est en aucune façon tenu de prouver que je commets une faute en né le lui livrant pas. Il n'a pas besoin de parler de faute, car Il ne m'intente pas une action en responsabilité, il ne fait que demander l'exécution d'une obligation initiale qui a pris naissance par le seul fait du contrat" (ROBIN. Georges. op. cit., p. 54-55).
} 
hipóteses, não há verdadeiramente obrigação até que, cometa um ato culposo, aquele então obrigado (tradução livre). ${ }^{102}$

Certamente nos parece possível dizer que Robin de fato vislumbrou a distinção das obrigações segundo seu objeto, no entanto, o fez de acordo com uma análise da responsabilização civil tida, fundamentalmente, como dependente de culpa. De forma que seriam duas as situações possíveis, de uma lado, o descumprimento culposo das obrigações impostas por força de lei ou de contrato, caso verdadeiro de responsabilização civil; de outro, os casos em que o devedor diretamente se obrigou àquela prestação determinada e uma vez verificada a condição (inadimplemento), acabaria obrigado à execução forçada, ainda que se traduzisse numa prestação pecuniária, a exemplo do que ocorre uma vez que se torne impossível a prestação em função do caso fortuito ou de força maior.

Assim, embora tenha notado que é possível se obrigar a um determinado resultado, a análise da conduta do devedor ainda prende-se à sua responsabilização culposa, fruto do descumprimento de uma obrigação preexistente, legal ou contratual, não a um tipo diverso e autônomo de prestação obrigacional que se traduz numa prestação de uma conduta determinada e específica do devedor de conduzir-se segundo as normas que regem sua arte ou ofício.

Em 1888, como nos da notícia Jean Van Ryn, ${ }^{103}$ a distinção entre as obrigações de meio e de resultado teria sido mais uma vez tocada, neste caso em estado latente, por um dos mais célebres doutrinadores de sua época.

Trata-se de artigo de Marcel Planiol dedicado a análise de decisões judiciais publicadas no ano de $1887 .^{104}$

O precitado artigo divide-se em seis diferentes itens dedicados, respectivamente, (i) aos contratos entre esposos, (ii) ao ônus probatório nos casos de acidente de trabalho, (iii) à clausula de exoneração de responsabilidade do patrão por acidentes de trabalho, (iv) à responsabilidade do locatário em caso de incêndio, (v) à responsabilidade do usufrutuário em idêntico caso e, finalmente, (iv) ao direito dos senhores feudais sobre os caminhos públicos na Bretanha.

\footnotetext{
102 "Le contrat comporte donc habituellement deux causes d'obligations ; l'une, initiale et formelle, c'est-àdire la prestation qui constitue, l'objet même du contrat, l'autre, virtuelle et conditionnelle dont l'objet est la réparation du préjudice causé par l'inexécution de la première. Nous àvons vu que dans certains cas spéciaux, on né rencontre que la première obligation; nous avons cite en ce sens le contrat d'après lequel on s'engage à assumer le risque des cas fortuits. A l'inverse, dans d'autres hypothèses, il n'y a véritablement obligation que lorsqu'une faute est commise par celui qui devient alors l'obligé" (ROBIN. Georges. op. cit., p. 58).

${ }^{103}$ RYN, Jean Van. op. cit., p. 18.

${ }^{104}$ Examen Doctrinal. Droit Civil. (Contrats à titre onéreux). (Décisions publiées en 1887). Revue Critique de Legislation et Jurisprudence. Paris, n. 17, p. 273-296, 1888.
} 
Contudo, somente no segundo item (ônus probatório nos casos de acidente de trabalho) é que o autor parece tocar a questão da distinção das obrigações entre as de meio e as de resultado.

Planiol percebeu que, fundamentalmente, enquanto os tribunais franceses fixavam a responsabilidade civil do empregador por acidentes de trabalho com base no art. 1.382 do Code Civil, ${ }^{105}$ dispositivo que institui a responsabilidade aquiliana, a doutrina se esforçava em proclamar a sua origem contratual e, por força disso, enquanto nos pretórios se impunha ao empregado o ônus de provar o ato culposo do empregador, os juristas, diante do dever patronal de proteger seus empregados adotando suficientes medidas de segurança, este fruto do contrato de trabalho firmado, considerava ser dele o ônus de provar não ter contribuído culposamente para a ocorrência do evento danoso.

Entretanto, se de um lado a jurisprudência falhava ao buscar o fundamento da responsabilidade civil patronal em caso de acidentes de trabalho, de outro, equivocava-se a doutrina ao inadequadamente inverter o ônus probatório sob a alegação de que ao devedor incumbiria provar o caso fortuito ou força maior que alega como causa do descumprimento de suas obrigações. ${ }^{106}$

Planiol ensina que a exigência de comprobação do caso fortuito alegado (art. 1302 do Code Civil) ${ }^{107}$ recairia apenas sobre o devedor se e quando este esteja obrigado a entregar ou restituir uma coisa ao credor. Desta forma, quando este se apresenta, portanto, para demandar a entrega ou restituição de uma coisa, apenas incumbe-lhe provar a existência da obrigação cujo cumprimento é reclamado, por outro lado, para que haja a liberação do devedor sem o seu cumprimento, cabe a este e não àquele provar que se lhe tenha tornado impossível entregar ou restituir a coisa por força do caso fortuito, já que é esta, ao menos em parte, a sua prestação. ${ }^{108}$

\footnotetext{
105 “Article 1382
}

Tout fait quelconque de l'homme, qui cause à autrui un dommage, oblige celui par la faute duquel il est arrivé, à le réparer".

${ }^{106}$ PLANIOL, Marcel. op. cit., p. 279-281.

107 "Article 1302.

Lorsque le corps certain et déterminé qui était l'objet de l'obligation, vient à périr, est mis hors du commerce, ou se perd de manière qu'on en ignore absolument l'existence, l'obligation est éteinte si la chose a péri ou a été perdue sans la faute du débiteur et avant qu'il fût en demeure.

Lors même que le débiteur est en demeure, et s'il ne s'est pas chargé des cas fortuits, l'obligation est éteinte dans le cas où la chose fût également périe chez le créancier si elle lui eût été livrée.

Le débiteur est tenu de prouver le cas fortuit qu'il allègue.

De quelque manière que la chose volée ait péri ou ait été perdue, sa perte ne dispense pas celui qui l'a soustraite, de la restitution du prix" (grifos nossos).

${ }^{108}$ PLANIOL, Marcel. op. cit., p. 281-282. 
Isso é inegavelmente verdade para os comodatários, locatários, depositários, entre outros. Contudo, como pontua o autor, "o patrão não tem como eles como eles duas obrigação; ele não tem senão uma. Ele não é obrigado a entregar o operário são e salvo a sua família após o término dos trabalhos, ele não é seu segurador. Ele é tão-somente obrigado a não comprometer sua segurança por falta de precaução" (tradução livre). ${ }^{109}$

Entretanto, para a efetiva responsabilização do empregador pelos acidentes de trabalho sofridos por seus empregados não bastaria a comprobação de que tenha aquele comprometido a segurança por "falta de precaução", faz-se igualmente necessário que se demonstre que foi este seu comportamento culposo que contribuiu efetivamente para a ocorrência do acidente.

Assim, a prova de que a conduta negligente do patrão tenha de fato influído na ocorrência do acidente caberia ao empregado, caso contrário estar-se-ia instituindo a responsabilização do empregador em todos os casos em que os elementos causadores do acidente restassem desconhecidos, impedindo, portanto, a adequada apreensão do nexo de causalidade entre o fato imputado e o dano ocasionado, o que acabaria por sujeitar-lhe a pesadíssimo ônus apenas e tão-somente pelo fato de contratar os serviços de terceiros. ${ }^{110}$

Pode-se perceber claramente, do quanto resta exposto, que Planiol, em seu citado artigo, com precisão distingue as obrigações que recaem sobre o empregador daquelas que envolvem a custódia da coisa por seu objeto. Aliás, é por força desta distinção que o autor é capaz de precisar a extensão da responsabilidade patronal, bem como a distribuição do ônus probatório. Entretanto, não nos parece que tais conclusões se possam atribuir à apreensão da diferença entre obrigações de prudência e diligência e obrigações de resultado.

Marcel Planiol considera que o fundamento da responsabilidade do empregador, aliás como nos demais casos de responsabilidade civil, é sempre a conduta culposa e, neste caso particular, decorre do contrato de trabalho firmado com seu empregado. Contrato este que lhe impõe, dentre outras, a obrigação de zelar por sua segurança do local de trabalho, para tanto providenciando o que seja eventualmente necessário.

Contudo, em que pese restar sobre o empregador a obrigação de diligenciar pela segurança no ambiente de trabalho, o seu descumprimento puro e simples não seria

\footnotetext{
109 “Le patron n'a pas comme elles deux obligations; Il n'en a qu'une. Il n'est pas tenu de rendre l'ouvrier san et sauf à sa famille après l"achèvement des travaux, Il n'est pas assureur. Il est seulement de ne pas comprometre as sécurité par um défaut de précaution" (PLANIOL, Marcel. op. cit., p. 282).

${ }^{110}$ PLANIOL, Marcel. op. cit., p. 283.
} 
suficiente para acarretar a sua responsabilização, pois faltaria ao empregado demonstrar o nexo de causalidade entre a conduta omissiva e o dano ocasionado. ${ }^{111}$

Isso porque "uma decisão condenando à reparação de um dano não é legalmente motivada senão quando constate uma relação de causalidade entre a falta cometida e o dano que ela obriga à reparação". ${ }^{112}$ Além disso, o ônus da prova do nexo de causalidade, ressalvado o caso de presunção legal, cabe sempre ao demandante. ${ }^{113}$

Assim, conclui o autor que, na medida em que não haveria na lei civil qualquer presunção legal de responsabilidade do empregar pelos acidentes de trabalho, caberia sempre ao empregado comprovar que a omissão de seu patrão em tomar as medidas necessárias para a criação de um ambiente de trabalho seguro é que teria consequiências diretas sobre a ocorrência do acidente, sem o que haveria de restar irressarcido pelos danos experimentados. ${ }^{114}$

Desta forma, é de se notar que embora o autor, com clareza e precisão, seja capaz de distinguir por seu objeto, a obrigação de zelo, neste particular bastante similar aos deveres de custódia, daquelas que envolvem, igualmente, o dever restituição ou entrega da coisa (locação, comodotado, etc), não se pode dizer que o faça por, num ou noutro caso, obrigar-se o empregador ao agere quantum possum (obrigação de meio) ou à entrega inafastável do resultado pactuado (obrigação de resultado).

${ }^{111}$ PLANIOL, Marcel. op. cit., p. 282.

112 PLANIOL, Marcel e RIPERT, Georges. Traité Pratique de Droit Civil Français. Paris: L.G.D.J., 1952, p. 730.

${ }_{113}$ PLANIOL, Marcel e RIPERT, Georges. op. cit., p. 731.

${ }^{114}$ PLANIOL, Marcel. Examen Doctrinal... op. cit., p. 282. 


\subsubsection{O surgimento da distinção na Alemanha.}

A conclusão de um negócio jurídico faz surgir para uma ou ambas as partes um encargo, uma obrigação de conduzir-se de determinada maneira, devendo serem aquilatadas as possibilidades do cumprimento da prestação fixada.

Contudo, vez ou outra, as coisas não correm como se previu e mesmo que não surjam controvérsias acerca do quanto se dispôs ou deixe de cumprir o devedor suas obrigações por força de sua vontade, podem surgir obstáculos que impeçam o regular cumprimento das obrigações assumidas. O homem propõe e Deus dispõe, ponderava Giorgio Giorgi. ${ }^{115}$

Assim é que, preocupado com estas questões e às vésperas da codificação, Kauf Bernhöft, apresentando uma análise do caso fortuito em seus comentários ao projeto de Código Civil alemão, ainda em 1889, alertou para a importância de se distinguir as obrigações segundo seu objeto:

todo vínculo obrigacional implica uma tensão da vontade do devedor em direção a certo resultado. Certamente o vínculo obrigacional pode ser de tal forma que o devedor é obrigado somente a fazer o quanto lhe seja possível para conseguir o resultado e com o qual ele é liberado independentemente do fim a ser efetivamente alcançado. Ou se há preocupação com o resultado em si mesmo, e então a obrigação não se extingue até que o resultado se realize, salvo a impossibilidade superveniente. ${ }^{116}$

Aliás, não é de se estranhar que a questão tenha surgido precisamente quando da análise da impossibilidade da prestação, pois "o problema consiste em identificar como se deve entender o requisito da 'impossibilidade' de prestar e ainda a sua 'não imputabilidade' ao devedor", nas palavras de Vincenzo Roppo. ${ }^{117}$

\footnotetext{
115 Teoria delle obbligazione nel diritto moderno italiano: esposta con la scorta della dottrina e della giurisprudenza. Firense: Cammelli, $6^{\mathrm{a}}$ ed., 1903, p. 6.

116 “Ogni rapporto obbligatorio - scrive Il Bernhöft - implica uma tensione della volontà del debitore in direzione di un certo risultato. Senonchè Il rapporto può essere di tal fatta dhe Il debitore è obbligato soltanto a fare quanto sta in lui per conseguire Il risultato, e com cio egli è Liberato indipendentmente dal raggiungimento effetivo dello scopo. Ovvero si há riguardo al risultato per se stesso, e allora l'obbligazione non si estingue finchè Il risultato non sai realizzato, salva l'impossibilità sopravvenuta" (BERNKÖFT, Kauf. Miethe und verquandte. apud MENGONI, Luigi . Obbligazioni “di risultato" e obbligazioni "di mezzi”. Milano: Francesco Vallardi, 1954, p.50).

117 O contrato. Tradução de COIMBRA, Ana, e GOMES, M. Januário C. Coimbra: Almedina, 2009, p. 255.
} 
Se, entretanto, Bernhöft foi quem pela primeira vez cogitou da distinção, deixou ele de nomear cada uma das espécies que descrevia, o que somente foi feito 8 anos mais tarde por H. A. Fischer, tendo chamado objetivas as obrigações que vinculavam o devedor à realização de um determinado resultado e subjetivas aquelas que lhe impunham um simples dever de esforço no sentido de realização de um fim visado pelas partes. ${ }^{118}$

Segundo Fischer o valor dogmático da classificação encontra-se na análise da responsabilidade civil por inadimplemento. Enquanto nas obrigações subjetivas o conceito de fortuito perderia importância, já que qualquer evento externo capaz de impor esforço e diligência superiores àqueles de fato assumidos pelo devedor seriam suficientes para exonerá-lo do dever de reparar (responsabilidade determinada pela culpa, portanto); nas obrigações objetivas o elemento subjetivo aparece tão-somente de maneira negativa, ele qualifica o fato externo que tornou impossível a execução da obrigação, ou seja, somente seria fortuito tudo quanto ocorresse sem a concorrência de culpa do devedor. Ou seja, à diversidade de conteúdo obrigacional corresponderia, igualmente, diversa natureza e limites da responsabilidade civil. ${ }^{119}$

Fundamentalmente, o que conclui este último autor tedesco é que nas obrigações subjetivas, na medida em que obrigam o devedor a um comportamento determinado, um esforço pessoal, um agere quantum possum para que se produza o resultado previamente fixado, não compreendido, no entanto, no objeto da obrigação assumida, a falta da prestação pura e simples não pode implicar a responsabilização do devedor, uma vez que não há, verdadeiramente, inadimplemento desde que tenha ele agido diligentemente.

É bem ressaltar, no entanto, como nos ensina Mengoni, que tanto a teoria de Fischer quanto aquela esboçada por Bernhöft decorrem de uma confusão conceitual. A definição de diligência como conteúdo da prestação obrigacional nas chamadas obrigações subjetivas não se distingue daquela utilizada como medida da culpabilidade, opondo-se à negligência, no caso de responsabilização por inadimplemento. Desta forma, o ponto de distinção das obrigações, originariamente colocado em seu objeto, acaba por deslocar-se para a responsabilização civil. ${ }^{120}$

Isso significa que surgem duas formas de responsabilização civil, uma fundada exclusivamente na culpa, quando o devedor se obrigou a um determinado comportamento,

\footnotetext{
${ }^{118}$ FISCHER, H. A. Vis major im Zusammenhang mit Unmöglichkeit der Leistung, p. 254. apud MENGONI, Luigi . op. cit., p.51.

${ }^{119}$ FISCHER, H. A. Vis major im Zusammenhang mit Unmöglichkeit der Leistung, p. 262-270. apud MENGONI, Luigi . op. cit., p.51-52.

${ }^{120}$ MENGONI, Luigi . op. cit., p.52-53.
} 
a ser realizado com diligência e dentro de suas forças, outra, em que a culpa estabelece, negativamente, os limites da impossibilidade objetiva da prestação, ou seja, desobrigando-o apenas diante do caso fortuito ou de força maior. 


\subsubsection{As obrigações de meio e de resultado na Itália (origem).}

Na Itália a questão da distinção das obrigações de meio e de resultado foi abordada, igualmente, diante da análise da liberação do devedor pela impossibilidade da prestação, no entanto, diferentemente de Fischer, Franceso Leone ${ }^{121}$ e Giuseppe Osti ${ }^{122}$ enxergaram que longe de importar uma diferença quanto ao fundamento da responsabilidade civil por inadimplemento, não tem ela outra significação se não a de determinar diversamente os extremos do que se considerar inadimplemento.

Essa idéia se pode encontrar com bastante clareza no artigo de Francesco Leone.

O autor, após realizar uma breve análise dos casos de responsabilidade extracontratual no direito romano, percebendo que nem sempre a culpa foi um requisito da responsabilização aquiliana e, então, defendendo, a fim de não se engessar a vida moderna com a imposição de um padrão de diligência extraordinário, a admissão de casos de responsabilidade objetiva no direito moderno, passa a analisar a responsabilização do devedor pela inexecução de obrigações contratuais.

Leone parte do pressuposto de que a responsabilidade contratual, qual a delitual, funda-se na culpa, no entanto, alerta para o fato de que, para a fixação precisa do inadimplemento que obriga ao ressarcimento, faz-se imprescindível, "distinguir os contratos nos quais o devedor é obrigado a prestar uma determinada atividade, daqueles em que é obrigado a conseguir um determinado resultado" (tradução livre). ${ }^{123}$

Segundo o autor, nessa primeira espécie de contrato, em que o devedor se obriga a prestar uma atividade determinada, ele há de conduzir-se segundo a diligência do "bonus pater familia". Caso em que a diligência normal na execução da atividade objeto de contratação diz respeito ao próprio conteúdo da prestação, de forma que, ainda que a realização da atividade objeto de contratação não venha a satisfazer o credor, não seria o devedor responsável, já que teria adequadamente adimplido sua obrigação, desde que não tenha incorrido em negligência, imprudência ou imperícia. De outra parte, quando tenha se

\footnotetext{
${ }^{121}$ La negligenza nella colpa extracontrattuale e contrattuale. Rivista di Diritto Civile. Milano: anno VII, p. 84-103, 1915.

${ }^{122}$ Revisione critica della teoria sulla impossibilita della prestazione. Rivista di Diritto Civile. Milano: anno X, fasc. 3, 4 e 5, p. 209-259, 313-360, e 417-471, 1918. O texto integral foi republicado em seus Scritti Giuridici. Milano: Giuffrè, 1973, p. 1-169, ao qual nos reportaremos.

123 "distinguere il contratti nel quali Il debitore è tenuto a prestare una determinata ativittá, da quelle in qui è tenuto a far consiguere un determinato risultato" (op. cit., p. 100).
} 
comprometido o devedor a entrega de um resultado determinado, somente seria ele liberado de sua obrigação sem o seu cumprimento quando se tenha tornado impossível atingi-lo por força de circunstâncias externas e a ele não imputáveis. ${ }^{124}$

Nestes termos é que Leone percebe a inexatidão de se afirmar que nalguns tipos contratuais, notadamente a compra e venda, encontre-se uma exceção ao pressuposto da culpabilidade na configuração da responsabilidade contratual.

O vendedor obriga-se à entrega da coisa, um resultado, portanto, assim, não há que se dizer que se tenha afastado a culpa uma vez que somente se veja ele desobrigado por força do caso fortuito ou da força maior, na verdade "isso acontece pois um mesmo fato pode constituir ou não a causa de liberação para o devedor, segundo disso dependa ou não o inadimplemento". ${ }^{125}$

É de se notar, desta forma, que segundo o pensamento de Leone a distinção das obrigações faz-se segundo o seu objeto (a realização de uma atividade ou a entrega de um resultado) e que a responsabilidade contratual, longe de dividir-se em duas categorias com fundamentos diversos, permanece una e fundada na culpa. O que se alcança é, tão-somente, um critério preciso para que se identificar o inadimplemento.

Essas idéias são compartilhadas por Giuseppe Osti, que diante de uma extensa análise da impossibilidade da prestação percebe que a doutrina, no geral, não trata com a devida importância a distinção entre o inadimplemento ocasionado por fato que implique a impossibilidade da prestação e aquele que ocorre sem o seu concurso. É em razão disso que passa a analisar, no vínculo obrigacional decorrente de um contrato, os limites da culpabilidade, considerada pressuposto da responsabilidade civil. ${ }^{126}$

Osti define diligência como "escolha, ou a cautela no escolher entre um modo de agir e um outro, entre um e outro comportamento, considerando um determinado fim a ser atingido" (tradução livre), diga este fim respeito uma regra geral de convivência ou um a resultado concreto de interesse privado.

\footnotetext{
124 "Nei primi senza dubbio Il debitore deve solo la diligenza del buon padre di famiglia; ma questa riguarda il contenuto della prestazione; ciò̀ il debitore che usa la diligenza riquesta dal rapporto contrattuale non è esente da responsbilità, per difetto di colpa, ma perchè há adempiuto la sua obbligazione.

Inveche il debitore, che si è obbligato a far consiguere un determinato risultato al creditore resta liberato solo quando l'inadempimento dipenda da una causa estranea a lui non imputabile, o da un caso fortuito o forza maggiore, e cio perche l'inadempimento dell'obbligazione è costituito della mancata prestazione" (LEONE, Francesco. op. cit., p. 100-101).

125 "Così accade che uno stesso fatto può costituire o no la causa di lerazioni pel debitore, a seconda che da esso dipenda o no l'inadempimento" (LEONE, Francesco. op. cit., p. 101).

${ }^{126}$ OSTI, Giuseppe. Revisione critica della teoria sulla impossibilita della prestazione. in Scritti Giuridici. Milano: Giuffrè, 1973, p. 110-111.
} 
A diligência, entretanto, somente se aplica à atividade realizada, enquanto medida do que possa concretamente atingir o fim colimado. ${ }^{127}$

É somente diante desta ordem de idéias que, para o autor, se torna possível dizer se a conduta adotada pelo devedor tenha sido adequada ou não para atingir determinado fim.

Contudo, prossegue, a análise da conduta adotada segundo a diligência reclamada somente teria sentido se não se der caráter absoluto ao fim buscado, pois:

[...] é evidente que se por qualquer motivo o respeito ao fim é decisivo, por este mesmo é excluído, por igual motivo, todo o respeito à intrínseca modalidade do comportamento com o qual este escopo seja perseguido pelo sujeito que o proporcione ou deva proporcioná-lo, assim é relevante somente o resultado efetivamente conseguido: uma só é a análise admitida em tal caso, e esta é se o fim que tenha sido perseguido foi ou não alcançado. Ao reverso, se por qualquer motivo é decisiva a valoração dos meios pelos quais o fim é perseguido e, mais precisamente, da atividade pela qual um determinado sujeito o tenha buscado, isso significa que pelo mesmo motivo a consideração do fim vem a ser posta em segundo lugar e ela vem a ser um mero critério para essa valoração, concorrendo com aqueles outros decorrentes da natureza intrínseca dos meios, da intrínseca modalidade do comportamento adotado segundo aquele fim (tradução livre). ${ }^{128}$

Assim, faz-se lícito dizer com Osti que as obrigações que têm por objeto uma prestação de diligência constituem apenas uma das categorias obrigacionais (obrigações de meio) e que na outra categoria (obrigações de resultado), a responsabilidade liga-se ao momento objetivo do inadimplemento, sem que para isso seja necessária a concorrência de culpa, ${ }^{129}$ assim, a diligência, considerada como critério de análise da conduta do devedor, não é de se considerar um critério geral, aplicável a todos os tipos de obrigação. ${ }^{130}$

127 "Diligenza non è altro che scelta, o cautela nello scegliere, fra um modo d'agire e un altro comportamento, in considerazione di um determinato scopo da raggiungere. Sai questo scopo Il rispetto di uma condizione generale di convivenza (ad es. il rispetto dell'incolumità pubblica), o sai um particulare risultato concreto che interessi determinati soggetti privati (ad es. la custodia di uma cosa locata, commodata, depositata, ecc.), il critério della diligenza si applica all'attività com cui il medesimo dev'essere perseguito, e si applica precisamente in quanto questa attività possa concretamente svolgersi in modi svariati tra i quali sai ammissibile la acelta, sichè non sai possibile determinare a priori $i$ sinfoli atti concreti com cui lo scopo stesso sara raggiunto" (OSTI, Giuseppe. op. cit., p. 117).

128 "Ora è evidente, che se per qualche riguardo la considerazione dello scopo è decisiva, per ciò stesso è esclusa, al medesimo riguardo, ogni considerazione delle intrinseche modalità del comportamento col qual elo scopo stesso sai perseguito dal soggetto che se lo propone o deve proporselo, sibbene è rilevante solo il risultato effetivamente conseguito: una solla è la ricerca ammissibile in tale ipotesi, e ciò̀ se lo scopo sai o no stato raggiunto. Per converso, se per qualche riguardo è decisiva la valutazione dei mezzi coi quali lo scopo è stato perseguito, e píu in particolare dell'atività con cui um determinato soggeto vi há inteso, cio significa che per il medesimo riguardo la considerazione dello scopo viene a esser posta in seconda línea e cioè viene a essere un mero critério per detta valutazione, concorrendovi com gli altri criteri desunti dalla natura intrínseca dei mezzi, dalle intrinseche modalità del comportamento intesso allo scopo stesso" (OSTI, Giuseppe. op. cit., p. 118).

${ }_{129}^{129}$ OSTI, Giuseppe. op. cit., p. 116.

130 Cumpre lembrar que os critérios da diligência e da culpa não são originários do campo do inadimplemento. Betti nos ensina que no direito romano clássico poderíamos encontrar quatro distintas 
Osti afirma, ainda, que nas obrigações de mero comportamento (obrigações de meio) o inadimplemento coincidiria com a culpa, ${ }^{131}$ o que poderia levar a entender que o critério da diligência seria suficiente para fixar o fato do inadimplemento.

No entanto, como observa Mengoni, pode o devedor, embora não tenha atendido a todos os requisitos necessários ao exato adimplemento do comportamento obrigatório, deixar de cumprir sua obrigação por força de um fato externo e a ele não imputável, o que implicaria sua liberação por caso fortuito ou força maior, a despeito de sua conduta culposa (negligente, imprudente ou imperita). ${ }^{132}$

Isso vem demonstrar que não necessariamente a ausência de culpa significa adimplemento, ou que a sua existência necessariamente importe no inadimplemento das obrigações do devedor.

$\mathrm{O}$ autor prossegue sua análise propondo um sistema de distinção entre as obrigações de mera diligência e as de resultado baseado numa análise dos caracteres econômico-sociais do fato ou ato que tenha dado origem à obrigação.

[...] Mas nós adotaremos uma classificação, que em grande parte se distanciará daquela tradicional: porque deveremos ter em vista, pelo quanto seja necessário fazer, a natureza intrínseca da causa, o caractere e o valor econômico-social do ato ou do fato em que a causa consiste, e isto

categorias de vinculo contratual, agrupáveis segundo os elementos específicos que compunham a responsabilidade por inadimplemento.

A primeira categoria, atinente aos casos de dever de custódia, colocava sobre o credor um tipo de responsabilidade objetiva, fundada no fato de ter recebido uma coisa e sobre ela ter poder de controle e conservação, já que não poderia ver-se liberado demonstrando ter diligentemente buscado conservar a coisa, apenas se a impossibilidade de sua restituição fosse devida a circunstâncias externas e a ele não imputáveis, somente na época pós-clássica que a responsabilidade pela custódia se transformou em responsabilidade por omissão (diligentia in custodiendo).

A segunda categoria, atinentes aos casos de obrigação de dar coisa certa, o devedor era responsável apenas pelos casos de culpa ou dolo comissivo, ou seja, se por um comportamento seu a coisa objeto da obrigação vem a perder-se.

A terceira categoria, dos vínculos obrigacionais permeados pela fidúcia personale e munidos de ação infamante, como a sociedade, a tutela, o mandato, o devedor respondia apenas por dolo, compreendido como um agir contrário à confiança depositada pela outra parte.

Por fim, a quarta categoria, atinentes aos vínculos obrigacionais ex fide bona, ou seja, concluídos entre romanos e peregrinos, em que o devedor era responsável pela conduta contrária à moral do tráfego comercial. Foi por força dessa diversidade de critérios de responsabilidade civil, incompreensível ao fím da época clássica, que os reelaborados pós-clássicos passaram a empenhar-se numa configuração da falta contratual segundo um sistema único e geral, cujas bases passaram a ser a culpa, o dolo e os casos específicos, criandose, assim, um dever geral de diligência.

Isso explicaria a aparente contradição das codificações italiana e francesa que estabeleceriam um dever geral de cautela (diligência) e ao, mesmo tempo, casos em que a sua quebra não importaria, necessariamente, a responsabilidade civil do devedor (BETTI, Emilio. Teoria Generale delle Obbligazioni. Milano: Giouffrè, 1953, v. I, p. 116-124), o que acuradamente foi notado por Osti.

${ }^{131}$ OSTI, Giuseppe. op. cit., p. 116.

${ }^{132}$ MENGONI, Luigi . op. cit., p.58. 
é a particular razão de utilidade que faz depender de um ato ou de um fato o surgimento de uma obrigação (tradução livre). ${ }^{133}$

Cumpre, neste ponto, esclarecer que cremos que Osti reporta-se à causa eficiente ou causa motriz das obrigações, ou seja, aquilo que respeita sempre uma a prioridade temporal, o que vem antes e que desencadeia os processos que derivarão no efeito (criação do vínculo obrigacional), sem o qual jamais viria ele a verificar-se, ${ }^{134}$ ou seja, o que pretende o autor é analisar as características e o valor econômico-social das fontes ou causas das obrigações, conforme Ruggiero, ${ }^{135} \mathrm{ou}$, em outras palavras, os fatos jurídicos que dão nascimento ao vínculo obrigacional segundo os parâmetros propostos (caracteres e valor econômico-social intrínsecos.

Nestes termos é que Osti propõe o agrupamento das obrigação em duas classes principais, (i) a primeiro das obrigações que se ligam de modo necessário a um comportamento do devedor dirigido a atingir um interesse particular e egoístico, (ii) a segunda, daquelas que se desligam de uma particular atividade do sujeito passivo ou dirigem-se a um fim altruístico.

Nesta primeiro categoria estariam compreendidas, assim, (a) as obrigações ex delicto ou quasi delicto, (b) as obrigações coligadas a um determinado exercício de um direito próprio do sujeito passivo e (c) aquelas decorrentes dos contratos sinalagmáticos; já na segunda, (a') todas as obrigações a título gratuito, bem como (b') aquelas decorrentes da lei e dos quase-contratos. ${ }^{136}$

As obrigações colocadas neste último grupo ligar-se-iam, pois o fim visado não corresponde a um interesse egoístico do sujeito passivo, tão-pouco a uma necessidade de se remover um estado de fato contrário ao estado de direito, mas antes, à realização de um interesse do sujeito ativo.

Osti aponta que as obrigações a título gratuito, uma vez constituídas, vinculariam o devedor a conduzir-se de maneira adequada e correta a fim de adimpli-las.

\footnotetext{
133 "[...] Ma noi adotteremo uma classificazione, che in gran parte si discosterà da quelle tradizionali: perocchè noi dovremo aver riguardo, più di quanto solitamente sia necessário fare, alla natura intrínseca della causa, al carattere e al valore economico-social dell'atto o des fatto in cui la causa consiste, e cioè alla particulare ragione di utilità che fa dipendere da un atto o da un fatto il sorgere di un'obbligazione" (OSTI, Giuseppe. op. cit., p. 123, grifos nossos).

${ }^{134}$ ARISTÓTELES. Metafísica. Tradução de VALLANDRO, Leonel. Porto Alegre: Editora Globo, 1969, p. 41 e GOROSTIAGA, Norberto. La causa en las obligaciones. Buenos Aires: Editorial Ideas, 1944, p. 242.

${ }^{135}$ RUGGIERO, Roberto de. Instituições de Direito Civil. Tradução de SANTOS, Ary dos. São Paulo: Saraiva, 1958 , v. 3, p. 99.

${ }_{136}$ OSTI, Giuseppe. op. cit., p. 124.
} 
Entretanto, como sustentar uma tal conclusão se o credor tem à sua disposição todos os meios coercitivos para exigir o cumprimento da obrigação que se assumiu em seu favor?

Nos responde o autor que embora o devedor tenha se obrigado a, de qualquer forma, incrementar o patrimônio do credor, não se poderia dele exigir um sacrifício tal que viesse a prejudicar-lhe a própria mantença, de maneira que se admitiriam, nesses casos, exceções ao cumprimento obrigacional com força liberatória versando sobre as características particulares do devedor (impossibilidade subjetiva), o que acaba por significar a sua vinculação apenas nos limites de suas forças, ${ }^{137}$ traduzindo-se, as obrigações a título gratuito, em obrigações de mera diligência (obrigações de meio).

Quanto às obrigações decorrentes de lei aduz Osti que, bem como aquelas derivadas da solidariedade social (obrigações a título gratuito), o vínculo formado é bastante menos intenso, já que não se pode admitir que aquele que é obrigado sem que para tanto concorra a sua vontade acabe ligado a uma obrigação de resultado. ${ }^{138}$

Um raciocínio similar poderia ser adotado quanto aos quase-contratos, isso porque, na medida em que traduzir-se-iam em expressões da solidariedade social, conduzir-se-iam à satisfação de um interesse do credor em decorrência de uma conduta altruística do devedor. Isso sem contar que envolvem a prestação de uma conduta simples e específica, sendo "suficiente usar a diligência do bom pai de família para executar a obrigação de modo congruo, vale dizer por executá-la com a diligência de um bom pai de família". ${ }^{139}$

Por força destas razões é que podemos concluir que todos os casos descritos por Osti neste segundo agrupamento das obrigações forçosamente serão casos de obrigações de meio, ou, em suas palavras, de mera diligência.

As obrigações colocadas no primeiro grupo, no entanto, reclamariam um análise um pouco diversa, pois não se há falar na realização de interesses altruísticos que sujeitassem o devedor e seu patrimônio, nem mesmo de situações em que se veria abrigado a despeito de sua vontade.

Qual seria, então, o conteúdo do dever de indenizar em matéria delitual ou quase-delitual, aquele que sujeita o credor nas obrigações que dependem do exercício de um direito do devedor ou nas decorrentes dos contratos sinalgmáticos?

\footnotetext{
${ }^{137}$ OSTI, Giuseppe. op. cit., p. 138-141.

${ }^{138}$ OSTI, Giuseppe. op. cit., p. 126-127.

139 “[...] sufficiente usare la diligenza di um buon padre di famiglia per eseguir l'obbligazione in modo côngruo, vale a dire per eseguirla com la diligenza di um bom padre di famiglia" (OSTI, Giuseppe. op. cit., p. 128).
} 
A análise do dever de reparar por força de um delito ou quase-delito passa, segundo Osti, pela garantia do ordenamento jurídico da autonomia patrimonial de cada sujeito.

Para que isso se realize, o direito limita a liberdade pessoal de todos os sujeitos a ele submetidos, impondo a cada um deles o dever de conduzir-se de forma a evitar invasões à esfera de autonomia alheia. Veda, portanto, que qualquer pessoa se conduza de forma a causar dano a outrem. ${ }^{140}$

Desta forma, a qualquer diminuição patrimonial decorrente de danos ilegitimamente causados, o direito vincularia o dever de restituição in integrum do patrimônio lesado.

Trata-se este do preciso objeto da obrigação de reparar, o que imporia ao devedor um resultado concreto em proveito do sujeito lesado, ou seja, tratar-se-ia, a obrigação de indenizar pelo danos causados ilegitimamente, de obrigações de resultado.

Tal reintegração constitui precisamente o objeto da obrigação do delito ou quase-delito; e é, portanto, um resultado concreto, o qual é imposto ao devedor, abstração feita às considerações sobre o modo ou os meios pelos quais ele deva prover a sua atuação, pois só com a efetiva prestação daquele resultado concreto, só com a efetiva reintegração do patrimônio lesado, vem a realizar-se novamente a condição de autônoma coexistência dos patrimônios, que o direito garante, e que o ato ilícito danoso altera (tradução livre). ${ }^{141}$

Mais uma vez e com um raciocínio bastante similar o autor procede à análise das obrigações que são coligadas ao exercício de um direito do devedor.

É o caso das obrigações $o b$ rem, que em essência estabelecem um vínculo obrigacional que se impõe ao sujeito investido de determinado poder sobre uma coisa.

Nas obrigações reais ou propter rem, seria impossível ao devedor eximir-se do cumprimento obrigacional alegando a possibilidade de, em virtude da prestação, vir a sofrer graves danos patrimoniais. O que igualmente se pode dizer do condômino ou do titular de imóvel gravado de servidão predial que pretendessem desligar-se da obrigação de conservação da coisa esposando idênticos motivos.

$\mathrm{O}$ ordenamento jurídico, na opinião daquele autor, dirige-se pela lógica de que o exercício de um direito, quando sobre ele pese um ônus, não se poderá fazer sem que seja este adequadamente cumprido, do contrário seria turbado o equilíbrio jurídico.

\footnotetext{
${ }^{140}$ OSTI, Giuseppe. op. cit., p. 134.

141 "Tale reintegrazione costituisce precisamente l'oggeto dell'obbligazione da delitto o da quase delitto; ed è dunque un resultamento concreto, cui è tenuto l'obligato astrazion fatta da ogni rigaurdo al modod e ai mezzi com cui egli debba provvedere ad attuarlo, poichè solo com l'effetiva apprestazione di quel resultamento concreto, solo com l'effetiva reintegrazione del patrimônio leso, vengono a realizzarsi nuovamente le condizioni di autonoma coesistenza dei patrimoni, che il diritto garantisce, e che l'atto illecito dannoso porta ad alterare" (OSTI, Giuseppe. op. cit., p. 134).
} 
A particular utilidade assegurada pelo ordenamento jurídico é que exige o cumprimento do ônus que sobre seu titular pesa, não basta que para tanto empregue o melhor de suas forças, mas sim que efetivamente cumpra a obrigação que lhe é imposta, o que, por sua vez, vem autorizar a conclusão de que, também neste caso, é de se falar em obrigação de resultado. ${ }^{142}$

Com relação aos contratos sinalagmáticos, Osti divide sua análise, mais uma vez, em dois grupos, aqueles dos contratos que envolvem um dare e aqueles que vinculam o devedor a um facere.

Os contratos que envolvem uma transferência de um direito ou de uma coisa consistem na imediata atribuição de sua propriedade ao credor e, em sendo onerosos, na contraprestação de uma quantia equivalente de outro bem ou direito, seja ele dinheiro ou não, sem o que não se realizaria o seu fim econômico-social.

Assim, é necessário, nestas hipóteses, assegurar-se a qualquer das partes a disponibilidade da coisa ou direito recebida no tempo, sem o que se frustrariam os interesses deduzidos no contrato.

Essa necessidade de se assegurarem os interesses das partes de uso e gozo da coisa diante de sua pronta e indefectível transferência ao patrimônio do credor é que tornariam possível se concluir, ainda que implicitamente, que a obrigação assumida é a de efetivamente serem os bens transmitidos ao patrimônio da contra parte, sem o que restaria responsabilizado o devedor. Caso este, certamente, de obrigação de resultado. ${ }^{143}$

Idêntico raciocínio poderia ser adotado quanto aos contratos translativos por tempo determinado, tais como a locação, o comodato, entre outros.

Igualmente nestes contratos a obrigação que pesa sobre o devedor é a de efetivamente outorgar a seu credor o uso e gozo da coisa ou direito pelo tempo pactuado, não bastando que, a fim de o fazer, venha apenas se utilizar de mera diligência ou de esforços idôneos a fim de alcançar o seu adimplemento. ${ }^{144}$

Quais seriam então, para Osti, os casos de obrigação de mera diligência?

Segundo sua proposta seriam somente aqueles casos que não envolvessem a efetiva transferência de coisa ou direito para o uso ou gozo do devedor, quer seja ela realizada a termo ou não.

\footnotetext{
${ }^{142}$ OSTI, Giuseppe. op. cit., p. 134.

${ }^{143}$ OSTI, Giuseppe. op. cit., p. 146-148.

${ }^{144}$ OSTI, Giuseppe. op. cit., p. 152-153.
} 
Assim, em primeiro lugar, encontramos os contratos em que há transferência da coisa para guarda e conservação, já que não importaria para o devedor uma obrigação de efetivamente restituí-la, tão-somente a de, com seus melhores esforços, conservá-la e adequadamente protegê-la.

Isso nos afirma o autor porque a vantagem obtida pelo credor é uma atividade de administração diligente e adequada de seu patrimônio e não a efetiva transferência de um bem ao seu patrimônio. ${ }^{145}$

Também nos contratos que obrigassem o devedor a realizar uma determinada atividade, encontraríamos as obrigações de mera diligência, um vez que o dever de adequadamente conduzir-se para o sucesso do facere é, neste tipo de negócio, o objeto de contratação. ${ }^{146}$

Cumpre observar, no entanto, que o pensamento do autor italiano, senão incorreu no equivoco de Bernhöft e Fischer, que enxergaram sistemas de responsabilização diversos, a nosso ver, acabou por confundir a diligência, objeto das obrigações de meio, com a culpa, pressuposto da responsabilidade civil.

$\mathrm{O}$ vocábulo diligência, tanto na linguagem jurídica quanto na vulgar, assumiu um significado mais amplo que aquele originário. ${ }^{147}$

$\mathrm{Na}$ análise das obrigações que envolvem o exercício de uma determinada atividade técnica, a diligência é compreendida não só como o esforço envolvido na realização de um fim visado, como também na execução precisa da atividade a ser desenvolvida enquanto capaz de produzir aquele resultado buscado pelo credor.

Desta forma, trabalho diligente seria tanto aquele perpetrado com perícia, em respeito às regras técnicas atinentes ao particular mister desenvolvido, como aquele que melhor se adéqüe a de fato desembocar no fim que busca o credor alcançar. É nesta última hipótese que se pode dizer, conforme a exatidão do resultado, que se tenha realizado um trabalho diligente.

Entretanto, atividade diligente e atividade conforme o fim visado no vínculo obrigacional não são conceitos equivalentes.

A realização de um determinado serviço pode bem corresponder às regras técnicas que governam determinada arte ou ofício, sem que, contudo, o resultado pretendido pelo

\footnotetext{
${ }^{145}$ OSTI, Giuseppe. op. cit., p. 153.

${ }^{146}$ OSTI, Giuseppe. op. cit., p. 153-154.

${ }^{147}$ Como nos ensina Mengoni, o sentido amplo de diligência é decorrência da tardia transposição da máxima imperitia culpae adnumeratur, que encontra sua origem na responsabilidade civil delitual no direito romano, ao terreno da responsabilidade contratual (MENGONI, Luigi . op. cit., p. 11-12).
} 
credor seja alcançado. Igualmente, é possível que, embora do trabalho conduzido não se possa dizer que tenha de fato atendido a tais critérios, sendo qualitativamente ou quantitativamente inferior àquele que se esperaria de quem age com respeito às regras da adequada realização de um determinado ofício, tenha a prestação executada inequivocamente satisfeito o interesse visado pelo credor.

De maneira que se pode afirmar que uma coisa é tratar de uma medida utilizada para que se impeça um evento dano (diligência enquanto critério de imputabilidade de um fato), outra bastante diferente é estabelecer parâmetros segundo os quais se poderia proporcionar um resultado útil (diligência enquanto respeito aos critérios necessário para se atingir um fim visado). ${ }^{148}$

Segundo nos parece e em razão desta distinção, embora Osti tenha de fato proposto uma definição de diligência, faz uma análise das obrigações segundo a responsabilização do devedor inadimplente, fixando-se, portanto, na admissibilidade ou não deste eximir-se da obrigação não cumprida pela ausência de culpa-diligência, ou seja, de ter sido a sua atividade responsável ou não pela falta de cumprimento obrigacional.

Por isso é que notamos que nos casos em que o autor encontra obstáculos à alegação de condições pessoais (impossibilidade prestação de ordem subjetiva) para o descumprimento obrigacional, conclui ele serem hipóteses de obrigação de resultado, enquanto de outra parte, sendo-lhe isso possível, fala ele em obrigação de meio.

\footnotetext{
${ }^{148}$ D'AMICO, Giovanni. La responsabilità ex recepto e la distinzione tra obbligazioni "di mezzi" e "di risultato" - contributo alla teoria della responsabilità contrattuale. Napoli: Edizioni Scientifiche Italiane, 1999, p. 143.
} 


\subsubsection{As obrigações de meio e de resultado na França (origem).}

Se não se pode atribuir a Demogue a paternidade da classificação das obrigações em de meio e de resultado - na Alemanha, como se demonstrou, disso já tratavam os autores trinta e seis anos antes, na Itália, outros dez -, não se pode negar tenha sido ele o seu mais célebre disseminador.

Entretanto, diversamente do que ocorreu naqueles dois outros países da Europa, a análise de Demogue tem raízes num problema particularmente diverso.

Enquanto os juristas tedescos e itálicos analisavam a possibilidade ou impossibilidade da prestação, buscando fixar com precisão o momento do inadimplemento e os limites da imputabilidade da conduta que o acarreta, o autor francês formulou a classificação como uma alternativa a outra distinção, esta baseada na fonte das obrigações, que as agrupava em "contratuais" e "extracontratuais".

É precisamente pela análise dos sistemas de responsabilidade civil contratual e aquiliana, nomeadamente dos mecanismos de repartição do ônus probatório que cada um deles impõe às partes litigantes, que René Demogue elaborou sua teoria.

Contudo, embora o autor não pretendesse, ao menos expressamente, substituir a classificação adotada pelo Code Civil e baseada na diferença entre os fatos que dão origem ao vínculo obrigacional, o efeito direto da adoção de sua proposta seria, certamente, o de afastar a importância da distinção das obrigações em contratuais e extracontratuais.

[...] Com efeito, de uma parte Demogue considerava a pretendida diferença entre as ordens do ponto de vista do ônus probatório como sendo a "mais importante", e em seguida, atribuindo à distinção das obrigações de meio e de resultado o papel de divisor exclusivo, ele enfraqueceu ali mesmo, até a aniquilação, o interesse que ele poderia dela obter ao analisar a natureza contratual ou não da obrigação. ${ }^{149}$

Se hoje nos parece, entretanto, evidente a coexistência dos dois sistemas de responsabilização, o contratual e o extracontratual, sendo quase inevitável a adoção de sua distinção, foi, ao menos no direito moderno, em fins do século XIX que cada um deles foi

\footnotetext{
149 “[...] En effet, d'une part Demogue tenait la prétendue différence entre les ordres du point de vue de la charge de la preuve comme étant 'la plus importante', et par suite, en attribuant à la distinction des obligations de moyens e de résultat Le role de répartiteur exclusif, il affaiblissait par là-même jusqu'anéantir, l'intérêt qu'il pouvait y avoir à considérer la nature contractuelle ou non de l'obligation" (BELISSENT, Jean. Contribution à l'analyse de La distinction des obligations de moyens et des obligations de résultat à propos de l'évolution des ordres de responsabilité civile. Paris: L.G.D.J, 2001, p. 39).
} 
sistematicamente exposto e defendida a sua radical separação ou a incindível união de ambos. $^{150}$

A oposição absoluta entre culpa contratual e culpa delitual tornou-se discussão corrente entre os doutrinadores entre os anos cinqüenta e setenta do século XIX.

Era dominante a idéia de que a culpa contratual, diferentemente da delitual, deveria ser presumida e que o devedor, para exonerar-se de suas obrigações, deveria provar a superveniência de uma causa estranha e que acabou por impedi-lo de executar a sua prestação. Assim, a culpa pelo inadimplemento deixava de existir somente diante do caso fortuito ou força maior. ${ }^{151}$

No entanto, essas idéias seriam postas em cheque em função dos acidentes industriais e da questão do trabalho, que surgiria com enorme força nas décadas oitenta e noventa daquele século.

Assim forjado o delito civil sobre a base exclusiva da culpa, a questão dos acidentes do trabalho e da responsabilidade civil do patrão sem o seu concurso levaria a duas possibilidades, (i) ou alterar o seu princípio basilar, como fez Raymond Saleilles com a teoria do risco, deslocando-a para o terreno delitual, ${ }^{152}$ (ii) ou transportá-la ao terreno contratual, como faria Sainctelette. ${ }^{153}$

Surgiu, assim, em 1884 a tese de Charles Sainctelette De la responsabilité de la garantie, vigorosa defesa da dualidade dos sistemas de responsabilidade civil e da origem contratual da obrigação patronal de reparar os danos decorrentes de acidentes de trabalho. $^{154}$

Sainctelette parte da idéia da oposição absoluta entre a lei e o contrato, segundo ele as únicas duas fontes de obrigações, propondo, inclusive, a extinção do termo responsabilidade contratual para que viesse a ser substituído pelo termo responsabilidade da garantia.

\footnotetext{
${ }^{150}$ Como já se disse com Betti, no direito romano clássico os sistemas de responsabilização permaneciam inequivocamente distintos e sujeitos a diferentes pressupostos. Aliás, foram os reelaboradores pós-clássicos que iniciaram um movimento de sistematização e unificação das responsabilidades, pela primeira vez fazendo-a sustentar-se nos pressupostos da culpa e do dolo, mantendo-se, contudo, os diferentes casos específicos que governavam cada um dos contratos (Teoria Generale delle Obbligazioni. Milano: Giouffrè, 1953, v. I, p. 116-124).

E, por fim, foi somente com Mommsen e Windscheid que a culpabilidade passou a ser pressuposto caracterizador do inadimplemento contratual (OSTI, Giuseppe. op. cit., p. 31-34).

${ }^{151}$ REMY, Philippe. La "responsabilité contractuelle": histoire d'um faux concept. in Revue Trimestrielle de Droit Civil. n. 96, p. 330, 1997.

${ }^{152}$ Les accidents de travail et la responsabilité civil (Essai d'une théorie objective de la responsabilité délictuelle). Paris: Arthur Rousseau, 1897.

${ }^{153}$ REMY, Philippe. op. cit., p. 331.

154 VINEY, Geneviève. Traité de Droit Civil. Les Obligations. La responsabilité: conditions. Coordenação de Jacques Ghestin. Paris: L.G.D.J., 1982, p. 193.
} 
Uma tão absoluta distinção demandaria a aplicação de sistemas absolutamente diversos.

A responsabilidade tem por função assegurar o respeito às leis, obra da responsabilidade; a garantia tem por finalidade assegurar o respeito aos contratos, obra da vontade privada. Toda questão de responsabilidade é, portanto, atinente à ordem pública e não pode ser resolvida se não em conformidade com as leis. Toda questão de garantia não diz respeito se não aos interesses privados e pode ser resolvida conforme a vontade e segundo as pessoas a que ela concerne.

[...] existe, portanto, entre a garantia e a responsabilidade a diferença entre a obrigação e a promessa, entre o contrato e a lei de ordem pública, entre a vontade privada e a vontade pública. É confundir aquilo que é, e deve ser distinguido, submeter uma destas situações ao regramento feito para a outra. Reger as relações contratuais pelas regras da responsabilidade é desconhecer o fato, chocar a razão, violar a justiça. ${ }^{155}$

No momento em que veio formulada, a tese de Sainetclette gozava do apoio da quase unanimidade dos juristas. ${ }^{156}$

Foi mais tarde, em 1892, que Grandmoulin propôs-se a combater a teoria dualista em sua tese de doutorado De l'unité de la responsabilité ou nature délictuelle de la responsabilité pour violation des obligations contractuelles.

Afirmava o então jovem autor que a obrigação inicial, nascida dos contratos, extingue-se com a impossibilidade da prestação, seja ela causada por um fato estranho ou pelo comportamento do devedor.

Assim, a obrigação de reparar os danos causados, sejam eles fruto da quebra de um dever legal de conduta ou de um contrato, não é um desdobramento da obrigação primitiva, trata-se de outro vínculo obrigacional que vem substituí-la e, independentemente do fato que tenha feito surgir a obrigação originária (a lei ou o contrato), têm este a sua origem sempre na lei. $^{157}$

\footnotetext{
155 "La responsabilité a pour fonction d'assurer le respect des lois, oevre de la volonté publique; la garantie, a pour but d'assurer Le respect des contrats, oevre des volontés privées. Toute question de responsabilité est donc affaire d'ordre public et de peut être résolue que conformément aux lois. Toute question de garantie n'est affaire que d'intérêts prives et peut être résolue au gré et à la guise des personnes qu'elle concerne. [...] il y a donc de la garantie à la responsabilité la différence à l'engagement, du contrat à la loi d'ordre public, des volontés privées à la volonté publique. C'est confondre CE qui faites pour l'autre. Régir lês relations contractuelles par lês règles de la responsabilité c'est méconnaitre Le fait, choquer la raison, violer la justice" (SAINCTELETTE, Charles. De la responsabilité de la garantie. p. 15-44, apud VINNEY, Geneviève. op. cit., p. 194).

${ }^{156}$ AUBRY, Charles, RAU, Greta. Droit Civil Français d'après la méthode de Zacharie. Paris: Marchal e Billard, $4^{a}$ ed., 1871, t. 4, p. 100-103; LAURENT, François. Principes de Droit Civil Français. Bruxelles: Bruylant-Christophe \& Cie, $3^{\mathrm{a}}$ ed., 1878, t. XVI, n. 213; DEMOLOMBE, Jean Charles Florent. Cours de Code Napoleon. Paris: Hachette, $4^{\text {a }}$ ed., 1869, t. XXI, n. 361; LABBÈ, J. E. in Journal du Palais, p. 79-91.

${ }^{157}$ GRANDMOULIN, Jean. De l'unité de la responsabilité ou nature délictuelle de la responsabilité pour violation des obligations contractuelles. p. 7, apud VINNEY, Geneviève. op. cit., p. 194.
} 
A pena que vai fixar definitivamente as bases da teoria unitária da responsabilidade civil, entretanto, é a de Marcel Planiol, em sua proposta de "salvar a culpa" dos ataques que sofreu com a teoria do risco. ${ }^{158}$

Planiol nota que a questão de se fixar qual a fonte da obrigação de indenizar os danos sofridos por acidentes de trabalho, na verdade, é uma tentativa de se fixar as regras atinentes ao ônus probatório. ${ }^{159}$ Pois a sua origem contratual, segundo a opinião corrente, faria presumir a culpa, a delitual, imporia ao autor demonstrá-la.

Contudo, para o autor, seja na responsabilidade delitual, seja na contratual, o devedor sempre vai estar ligado a uma obrigação, de forma que tratar o seu descumprimento, do ponto de vista da culpa, de maneira diversa seria um capricho sem motivo.

[...] a diferença que pretendemos estabelecer entre as duas espécies de culpa carece inteiramente de base; não se não uma espécie de ilusão resultante de um exame superficial: uma e outra criam igualmente uma obrigação, aquele de reparar por uma indenização o dano o dano causado; uma e outra supõem igualmente a existência de uma obrigação anterior; uma e outra consistem igualmente em um fato que violou aquela obrigação [...] tratar de uma maneira diferente dois devedores que podemos supor tenham obrigações similares por seu objeto, um em virtude de lei, o outro em virtude de uma convenção[...] seria um capricho sem motivo, um absurdo legislativo (tradução livre). ${ }^{160}$

Embora, como nos ensina Remy, Planiol baseie-se na confusão semântica do termo obrigação em seu sentido técnico-jurídico e no sentido corrente (dever), a sua teoria satisfazia, a um só tempo, os reclamos do positivismo legalista, pois diferentemente de Grandmoulin, não apagava a diferença entre os contratos e a lei, e do voluntarismo, o que pode explicar o seu inquestionável sucesso. ${ }^{161}$

A conclusão de que a despeito da diferença de fonte, as conseqüências das obrigações formadas seriam as mesmas, sujeitando-se a pressupostos similares, passa ser correntemente defendida pelos autores no início do século XX.

A diferença entre as duas ordens de responsabilidade, que passa a ser um postulado e deixa de ser colocada em cheque, perdendo o seu antigo papel no direito civil, passaria,

\footnotetext{
${ }^{158}$ REMY, Philippe. op. cit., p. 332.

${ }^{159}$ Traité élémentaire de droit civil. Paris: L.G.D.J, $4^{\mathrm{a}}$ ed., 1906, t. II, n. 1857.

160 "la différence que l'on prétend établir entre les deux espèces de fautes manque entièrement de base; CE n'est qu'une sorte d'illusion résultat d'um examen superficiel: l'une et l'autre faute créent également une obligation, celle de réparer par une indemnité Le dommage cause; l'une et l'autre supposent également l'existence d'une obligation antérieure; l'une 'lautre consistent également en un fait qui est la violation de cette obligation [....] traiter d'une manière différente deux débiteurs qu'on peut supposer tenus d'obligation semblables par leur objet, l'um em vertu de la loi, l'autre em vertu d'une convention [...] serait un caprice sans motif, une absurdité législative" (op. cit., n. 876.

${ }^{161}$ REMY, Philippe. op. cit., p. 333-335.
} 
assim, a uma mera preocupação com as diferenças de regime que cada um dos ramos demanda. ${ }^{162}$ Diferenças estas bastante mais tímidas, uma vez que a culpa deixa de ter tratamento autônomo.

É nesse cenário que vamos encontrar o pensamento de Demogue e a sua proposta de classificação das obrigações.

O autor, partidário da tese da unidade parcial, ${ }^{163}$ considerava que, embora as duas ordens de responsabilidade estivessem fundadas sobre os mesmos pressupostos racionais, diferenciavam-se, ainda que de maneira tênue, quanto a seu regime de aplicação, sendo a mais notável diferença a da diversa distribuição do ônus probatório, ${ }^{164}$ como já tivemos oportunidade de dizer.

Assim, criticando as posições de Sainctelette e Grandmoulin, Demogue conclui que o sistema de distribuição do ônus probatório é o mesmo tanto na responsabilidade civil de origem delitual quanto por descumprimento contratual.

É então que faz notar que as obrigações a que sujeita o devedor nem sempre são da mesma natureza, podendo ele obrigar-se à entrega de um resultado ou de adotar certas medidas específicas capazes de conduzi-lo a um de terminado fim, no que vê o autor uma analogia à divisão dos delitos em formais (o comportamento do sujeito é considerado pelo direito como um fato punível) e materiais (a consumação do delito depende da assunção de determinado resultado descrito pela norma incriminante para que se torne punível) no Direito Penal. $^{165}$

Desta forma, nas obrigações de resultado, bastaria ao autor provar a existência de uma obrigação e sua inexecução, liberando-se o devedor apenas se comprovar ter a prestação se tornado impossível em razão do caso fortuito ou força maior. Por outro lado, nas obrigação de meio, deveria o autor, além de fazer prova daqueles dois fatos, demonstrar que teria o devedor agido com culpa ou dolo.

Seria este o caso, segundo Demogue, do banqueiro que se obriga a manter seguro os objetos que lhe são entregues para a guarda em caixas de depósito, ou mesmo, do devedor que se obriga à guarda e conservação de um imóvel.

\footnotetext{
${ }^{162}$ VINEY, Geneviève. op. cit., p. 196.

163 “Notre conclusion est donc qu'à défaut de différence rationnelle, il existe dans le droit positif quelque différences assez minimes entre la responsabilité délictuelle et la responsabilité délictuelle. C'est le système adopté par M. Planiol" (DEMOGUE, René. Traité des Obligations en Général. Paris: Librarie Arthur Rousseau, 1925, v. V, p. 525).

${ }^{164}$ DEMOGUE, René. op. cit., v. V, p. 536-537.

${ }^{165}$ DEMOGUE, René. op. cit., v. V, p. 536-537.
} 
Seria, ainda, de meio a obrigação do patrão de adotar as medidas adequadas para salvaguardar a saúde de seus empregados, bem como aquele que surge em todos os casos em que se impõem a adoção de certas medidas de prudência e diligência ao devedor.

Entre as obrigações de resultado o autor coloca as obrigações do transportador de pessoas, dos contratos de locação.

É após a análise destes contratos específicos, no entanto, que o autor afirma que "a responsabilidade por culpa não é a única que existe. De uma maneira geral se sustenta que se é responsável pelo risco criado, o que quer dizer que cabe a outrem não lesar. É, portanto, por um resultado que se é responsável" (tradução livre). ${ }^{166}$

Este seu particular posicionamento nos parece é que pode explicar o pensamento corrente da doutrina francesa que procura aproximar a distinção por ele proposta daquela que se faz acerca da ausência ou não da culpa como pressuposto da responsabilidade.

Neste quadro, seriam casos de responsabilidade subjetiva aqueles em que se pode dizer seja a obrigação de meio, enquanto seriam casos de responsabilidade objetiva aqueles em que se nota uma obrigação de resultado.

Parece-nos, no entanto, que isso se deva à confusão de Demogue, qual aquela que se notou em Osti, a respeito do significado do termo diligência.

Demogue em sua obra adota uma definição de culpa que se pode chamar psicológica, ou seja, caracteriza-se pela falha de representação do agente da previsibilidade de ocorrência de um dano em decorrência de sua ação. ${ }^{167}$

Essa falha de previsibilidade, segundo o autor, não haveria de se restringir, no entanto, às conseqüências materiais da ação (efeitos que sigam determinado evento segundo as leis naturais da causalidade), mas igualmente aqueles a que chama sociais, ou seja, a falha na previsibilidade do caráter ilícito da conduta adotada pelo devedor da obrigação de reparar. ${ }^{168}$

Nessa perspectiva, diligência seria uma tensão da vontade, um certo dever de concentração. Seria aquele esforço psíquico de manutenção da atenção do agente na condução de certa atividade para bem realizá-la. E a culpa, em razão disso, consistiria na falta de um tal esforço, na quebra da concentração, impedindo o autor de vislumbrar as

\footnotetext{
166 “la responsabilité pour faute n'est pas la seule qui existe. D'une façon générale on a soutenu que l'on étai responsable du risque créé, ce qui veut dire que l'on doit à autrui de ne pas léser. C'est donc um résultat dont on est responsable" (DEMOGUE, René. op. cit., v. V, p. 542).

${ }^{167}$ DEMOGUE, René. op. cit., v. V, p. 423-424.

${ }^{168}$ DEMOGUE, René. op. cit., v. V, p. 441-442.
} 
conseqüências de seus atos ou antever as medidas que teria de adotar a fim de evitar quaisquer efeitos nocivos deles decorrentes. ${ }^{169}$

Uma vez ligadas assim a diligência e a culpa, pois a quebra da primeira implicaria a verificação da segunda, desde que ausentes quaisquer causas externas e insuperáveis (caso fortuito ou força maior) que impedissem o autor de evitar o dano, é de se compreender, segundo nos parece, a conclusão de Demogue de que nos casos em que não se admite a responsabilização por culpa esteja-se diante de obrigações de resultado, bem como a ligação da distinção que propõe à divisão da responsabilidade civil em subjetiva e objetiva.

Podemos, a nosso juízo, ir além para dizer que é a falta de distinção entre diligentia in adimplendo e diligência necessária para evitar que o fim obrigacional não possa ser atingido (critério de responsabilização civil) que perpassa, inclusive, o critério proposto pelo autor para que se possa identificar cada uma das categoriais obrigacionais proposta.

Isso porque, segundo Demogue, em matéria delitual as obrigações seriam sempre de meio, excetuados os casos em que expressamente se determinasse ao devedor a responsabilização baseada no risco ou naqueles em que se presumisse sua culpa. Enquanto nas obrigações decorrentes de contrato, seria necessário, para distinguir as obrigações de meio das de resultado, analisar o fim contratual, as regras gerais a ele aplicáveis e a vontade das partes. ${ }^{170}$

Parece o autor apresentar como critério de distinção a necessidade de demonstração de culpa do autor do dano para sua responsabilização, seja ela imposta pela lei ou, em maior ou menor grau, pela vontade das partes.

Como se alertou na análise da obra de Osti, Demogue circunscreve o critério de diferenciação das obrigações de meio e de resultado ao elemento subjetivo para a responsabilização civil do devedor, ainda que proponha, em terreno contratual, a análise do fim contratual, as regras gerais a ele aplicáveis e a vontade das partes.

Isso porque o que se nota é que em lugar de buscar os requisitos para responsabilização civil do devedor inadimplente junto à lei, deverá o jurista realizar a análise do que determina o contrato, no que se pode notar a admissão da vontade das partes enquanto forma criadora de normas jurídicas.

O que, certamente, não é de se estranhar em função da época em que se apresenta a sua teoria.

\footnotetext{
${ }^{169}$ D’AMICO, Giovanni. op. cit., p. 138.

${ }^{170}$ DEMOGUE, René. op. cit., v. V, p. 543.
} 
Mesmo antes das grandes codificações os juristas já se apoiavam na doutrina jusnaturalista de Grotius e Pufendorf, que colocavam o contrato como ponto chave do sistema jurídico e, desta forma, encontravam na liberdade e na vontade os elementos criadores do direito. Estas são as idéias que viriam a alimentar os voluntaristas nos séculos seguintes. $^{171}$

Esse contrato, vínculo decorrente do consentimento mútuo de duas ou mais partes que se impõem reciprocamente a executar aquilo que prometeram, ${ }^{172}$ na medida em que é expressão de sua vontade, tem matéria tão infinita quanto a criatividade do espírito humano.

A autonomia da vontade e o consentimento, elemento formador do contrato, princípios cantados pelos doutrinadores do século XVIII, acordavam-se plenamente com o pensamento filosófico e econômico da época revolucionária na França.

Casado, assim, o dogma da vontade com a economia de mercado baseada na liberdade de iniciativa e na crença da igualdade de todos perante a lei, ${ }^{173}$ é que o consentimento viu-se abraçado pela codificação napoleônica. Tanto é assim que encontra-se expressamente elencado pelo art. 1.108 do Code Civil entre os elementos essenciais para a validade das convenções:

\section{Artigo 1108 \\ Quatro condições são essenciais para a validade de uma convenção: o consentimento das partes que se obrigam; sua capacidade de contratar; um objeto certo que forme a matéria do engajamento; uma causa lícita das obrigações (tradução livre). ${ }^{174}$}

A liberdade e a vontade das partes, perpassando as disposições do Code Civil, apresentadas como princípios pelos juristas de então, viriam no século XIX a ser expostas como teoria geral pelos sociólogos e filósofos.

Cada indivíduo é, na sociedade, essencialmente livre e para obrigar-se há de reconhecer voluntariamente o vínculo que sobre ele passa então a pesar.

${ }^{171}$ GOMES, Orlando. Transformações Gerais do Direito das Obrigações. São Paulo: RT, $2^{\mathrm{a}}$ ed, 1980, p. 71.

${ }_{172}$ Pode-se encontrar nesta definição de Domat (Les conventions sont des engagements qui se forment par le consentement mutuel de deux ou de plusieurs personnes qui se fonte entre eux une loi d'exécuter ce qu'ils promettent - op. cit., t. I, p. 61) as origens do art. 1.134 do Code Civil (Les conventions légalement formées tiennent lieu de loi à ceux qui les ont faites. Elles ne peuvent être révoquées que de leur consentement mutuel, ou pour les causes que la loi autorise. Elles doivent être exécutées de bonne foi).

${ }^{173}$ GOMES, Orlando. op. cit., p. 72-74.

174 “Article 1108

Quatre conditions sont essentielles pour la validité d'une convention :

Le consentement de la partie qui s'oblige;

Sa capacité de contracter ;

Un objet certain qui forme la matière de l'engagement;

Une cause licite dans l'obligation". 
Vontade, consentimento, autonomia da vontade, liberdade contratual e força vinculante do contrato baseado no quanto querido pelas partes são os pilares que passam a sustentar a concepção voluntarista do contrato e que se pode encontrar no pensamento de Demogue.

O contrato, nestes termos, se aperfeiçoará quando se tenha chegado a um consensus in idem, noutras palavras, quando o consentimento (coincidência de suas declarações de vontade que, procedendo de sujeitos diversos, concorrem a um fim comum) de ambas as partes recaia sobre o mesmo objeto.

Nessa perspectiva, embora sejam elementos distintos, pois consentimento supõe observar o contrato do ponto de vista dos sujeitos (validade da manifestação de vontade) e o objeto do ponto de vista da realidade material sobre a qual recaia, é inegável que aquele acaba por moldar o conteúdo deste, uma vez que o contrato somente se aperfeiçoará na medida em que se tenha alcançado um consensus in idem, ou seja, quando o consentimento de ambas as partes recaia sobre o mesmo objeto.

A vinculação contratual existiria, assim, desde que para cada parte se tenha formado claramente uma idéia de qual é o interesse protegido pelo direito com a conclusão perfeita do contrato. O que importa é se cada parte formou uma representação racional do que a outra tenha oferecido e se, de acordo com isso, tenha prestado o seu consentimento. $^{175}$

Objeto do contrato é, assim, aquilo sobre o que recai o consentimento, ou seja, aquela representação racional do interesse garantido pelo direito na formação daquele contrato em particular.

Dessa forma e nessa sentido, não só o consentimento recai sobre o objeto como também vem amoldá-lo segundo o interesse das partes contratantes.

Assim, num primeiro momento, podemos concluir que a distinção proposta por Demogue entre as obrigações de meio e de resultado de um lado depende da análise dos limites da responsabilização de cada uma das partes pelo inadimplemento que tenham sido fixados no contrato firmado, de outro, do objeto mesmo deste contrato e da regulação legal que a ele se impõe independentemente e a despeito do quanto querido por cada uma das partes.

${ }^{175}$ SAN JULIAN, Veronica. Objeto del Contrato. Barcelona: Bosch Editorial, 1996, p. 36. 
Entretanto, o critério distintivo das obrigações de meio e de resultado não residiria, segundo aquele autor, apenas nos limites da responsabilização das partes, determinada diretamente por sua vontade ou pela lei.

Demogue define as obrigação como uma situação jurídica que tem por finalidade uma ação ou abstenção de valor econômico ou moral que determinadas pessoas asseguram e, embora tenha sua origem tanto na lei quanto na vontade, a tônica de sua análise é de se direcionar para a sua execução, pois não é por outro motivo que tudo se conjuga. ${ }^{176}$

Isso, segundo nos parece, pode igualmente contribuir, além de se lembrar a concepção voluntarista que parece conduzir seu pensamento, não só o foco adotado pelo autor para distinguir as obrigações de meio das de resultado (sistemática da responsabilização do credor pela inexecução de sua obrigação), como a adoção de um outro critério, externo ao vínculo obrigacional e que guarda relação tão-somente com sua execução.

Trata-se este do risco de insucesso de uma determinada atividade.

Demogue considera que as atividades exercidas com independência pelo devedor seriam sempre de meio, enquanto aquelas em que o resultado buscado pode ser concretamente obtido, uma vez respeitadas as técnicas que regem uma determinada atividade ou ofício, traduzir-se-iam em obrigações de resultado.

Os profissionais que tem uma profissão liberal, noutras palavras, que exige uma independência em sua execução, como o médico, o advogado, não há sobre sua responsabilidade senão uma obrigação de meio. As atividades, que vão desde o pedreiro ao mais alto grau, até o arquiteto, comportam de ordinário uma obrigação de resultado. Pois o resultado pode ser atingido quase certamente com a técnica apropriada. ${ }^{177}$

Entretanto, embora o critério para distinção entre as obrigações de meio e de resultado tenha se deslocado para o risco, a álea, não se pode negligenciar o papel da vontade das partes.

Permanece possível, a cada uma das partes, assumir obrigações mais ou menos extensas.

Se a existência ou não de álea na atividade é critério para sua classificação, igualmente é de se considerar possível às partes que, assumindo o risco inerente ao

\footnotetext{
${ }^{176}$ DEMOGUE, René. op. cit., v. I, p. 16-18.

177 "Le professionel qui a une profession libérale, c'est-à-dire exigeant une indépendence dans l'éxecution comme le médicin, l'avocat n'a as charge q'une obligation de moyen. Le métier, qui va depuis le manouvre jusqu'au plus haut degré, jusqu'à l'architecte, comporte d'ordinaire obligation de résultat. Car le résultat peut être atteint presque sûrement avec technique appropriée" (DEMOGUE, René. op. cit., v. V, p. 544).
} 
comportamento prescrito como devido, transformem as obrigações assumidas numa e noutra espécie livremente. ${ }^{178}$

Assim, se de um lado um novo critério distintivo é proposto, de outro permanece em vigor aquele primeiro, baseado na vontade das partes e no regulamente que livremente impuserem às obrigações que vieram a assumir.

Se a Demogue, como vimos, não se pode atribuir a paternidade da distinção ora estudada e certamente contra a sua teoria se possam levantar críticas como a que vem de se enunciar, não é menos verdade que, historicamente, teve grande importância, uma vez que apresentou uma alternativa à interpretação de dos art. 1.137 e 1.147 do Code Civil à doutrina francesa. ${ }^{179}$

O primeiro dispositivo determina os limites do dever de custódia nas obrigações de dar, impondo ao devedor que se conduza como bom pai de família; ${ }^{180}$ o segundo preceitua que toda inexecução de uma obrigação tem por efeito a responsabilização do devedor, excetuado o caso em que demonstre ter deixado de lhe dar cumprimento em razão de força maior ou de caso fortuito. ${ }^{181}$

Como forma de se sanar a aparente antinomia existentes entre os precitados artifos diversas foram as propostas teóricas apresentadas pela doutrina francesa.

Num primeiro momento considerou-se que o art. 1.137 traria uma exceção à regra geral disposta pelo art. 1.147, entretanto, como se admitir que somente ao responsável pela guarda de uma coisa se admitisse uma exceção, enunciada, aliás, antes mesmo da regra geral que excepciona? ${ }^{182}$

\footnotetext{
${ }^{178}$ LE TOURNEAU, Philippe. La responsabilité Civile. Paris: Dalloz, $2^{\mathrm{a}}$ ed., p. 377.

179 É importante notar neste ponto, como nos ensina Mengoni, que a doutrina francesa carece de uma distinção clara entre a diligência compreendida como critério de imputação e aquele definidora dos comportamentos adequados à boa condução de uma atividade (MENGONI, Luigi . op. cit., p. 58), o que, segundo nos parece, poderia igualmente explicar aquela aparente contradição.

180 "Article 1137

L'obligation de veiller à la conservation de la chose, soit que la convention n'ait pour objet que l'utilité de l'une des parties, soit qu'elle ait pour objet leur utilité commune, soumet celui qui en est chargé à y apporter tous les soins d'un bon père de famille.

Cette obligation est plus ou moins étendue relativement à certains contrats, dont les effets, à cet égard, sont expliqués sous les titres qui les concernent".

181 "Article 1147

Le débiteur est condamné, s'il y a lieu, au paiement de dommages et intérêts, soit à raison de l'inexécution de l'obligation, soit à raison du retard dans l'exécution, toutes les fois qu'il ne justifie pas que l'inexécution provient d'une cause étrangère qui ne peut lui être imputée, encore qu'il n'y ait aucune mauvaise foi de sa part".

${ }^{182}$ VINEY, Geneviève. op. cit., p. 440.
} 
Josserand, mais tarde, sugeriu que os artigos em questão teriam campo de incidência diverso. O art. 1.147 aplicar-se-ia às obrigações de fazer e de não fazer, enquanto o art. 1.137 somente seria aplicável às obrigações de dar. ${ }^{183}$

Uma tal solução, contudo, deixaria de explicar o fato de que o art. 1.147 do Code Civil encontra-se em seção destinada a regular as consequiências da inexecução de todas as obrigações, não se restringindo a um tipo específico.

Sustentou-se, então, que o art. 1.137 não diria respeito ao objeto da obrigação que disciplina, mas tão-somente quanto a sua existência, enquanto o art. 1.147 fixaria o conteúdo das obrigações contratuais. ${ }^{184}$

O que certamente parece desnaturar os termos da norma prescrita naquele primeiro dispositivo.

Foi somente a proposta teórica de Demogue que, em 1925, gozou de maior aceitação doutrinária.

Segundo o autor o art. 1.137 do Code Civil impõe ao devedor a execução de uma de meio, ou seja, o devedor se obrigaria à manutenção diligente e adequada da coisa sob sua guarda, ao passo que o art. 1.147 faria sobre ele pesar uma obrigação de resultado precisa e determinada. ${ }^{185}$

Isso implica dizer que a não há na lei normas que definam de maneira única e permanente o conteúdo de todas as obrigações.

Admitiu-se, ao contrário, que as obrigações podem apresentar um conteúdo variável, apresentando-se uma solução diversa para o problema até então enfrentada por grande parte da doutrina.

Pode-se dizer, além disso, que antes da proposta teórica de Demogue, a controvérsia acerca dos fundamentos da responsabilização civil permanecia bastante aguçada na doutrina. Movimentando-se entre a culpa e a falta dela, como nas teorias da garantia ou do risco, ${ }^{186}$ sem que se pudesse, contudo, dar resposta confortável aos problemas surgidos com a era industrial, nomeadamente, de tornar possível aos operários a obtenção de reparação pelos danos sofridos no ambiente de trabalho.

\footnotetext{
183 JOSSERAND, Louis. Cours de droit civil positive français. Paris: Sirey, $3^{\text {a }}$ ed., 1938, t. II, p. 235.

${ }^{184}$ PLANIOL, Marcel. Traité élémentaire de droit civil. op. cit., p. 297.

${ }^{185}$ DEMOGUE, René. op. cit., v. I, p. 537-544.

${ }^{186}$ BELISSENT, Jean. op. cit., p. 169-170.
} 
Talvez seja exatamente por isso que na França a distinção proposta por Demogue logo angariou tão fervorosos defensores, como os irmãos Mazeud, ${ }^{187}$ Savatier, ${ }^{188}$ Tunc, ${ }^{189}$ Frossard e Belissent.

É de se notar, ainda, que pouco mais de dez anos após a publicação do Traité de Demogue, em 20 de maio de 1936, a distinção entre as obrigações de meio e de resultado recebeu a consagração da Corte de Cassação, no famoso julgado "Mercier", que tratou da responsabilidade civil médica:

Formar-se entre o médico e seu cliente um verdadeiro contrato que comporta para o médico prático o compromisso de prestar cuidados atentos, conscienciosos e, exceção feita a circunstâncias excepcionais, conformes com os dados adquiridos da ciência; a violação, mesmo involuntária, dessa obrigação contratual é sancionada por uma responsabilidade do mesmo modo e natureza, igualmente contratual (tradução livre). ${ }^{190}$

Além de estabelecer a origem contratual da responsabilização pelos erros médicos, o arresto "Mercier" também acolheu a distinção entre as obrigações de meio e de resultado, na medida em que reconhece que o médico não se obriga à cura do paciente, mas apenas à execução adequada e precisa das normas técnicas que sua ciência prescreve para o tratamento de cada enfermidade.

Em que pese a sua acolhida por doutrinares de renome, a proposta de distinção apresentada por Demogue não passaria livre de críticas de pensadores de igual importância para o direito, como Capitant, que a considerava digna de pena, ${ }^{191}$ além de Marton ${ }^{192}$ e de Esmein, ${ }^{193}$ como mais detidamente se verá.

No entanto, a despeito das críticas levantadas ao pensamento do autor francês, a distinção que tornou célebre permaneceu rendendo frutos, tendo sido criadas, inclusive, outras subdivisões aplicáveis àquelas duas categorias primarias.

Assim é que a Corte de Cassação francesa, em acórdão proferido em 21 de maio 1996 no caso "Bouchard", entendeu existirem obrigações de meio reforçadas, pois uma

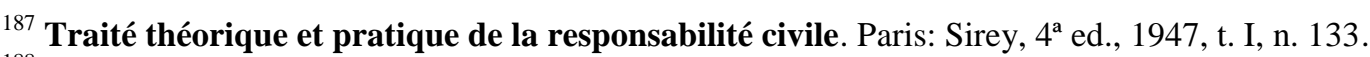

${ }^{188}$ Traité de la responsabilité civile en droit français. Paris : L. G. D. J, $2^{\text {a }}$ ed., 1951, t. I, n. 113.

${ }^{189}$ Distinzione delle obbligazione di risultadto e delle obbligazione di diligenza. Nuova Rivista del Diritto Commerciale. Pisa, t. I, p. 126-145, 1947-1948.

190 "Il se forme entre le médicin et sont client um véritable contrat comportant pour le praticien l'engagement de donner des soins attentifs, consciencieux et, sous reserve faite de circonstances exceptionnelles, conformes aux données acquises de la science; la violation, même involontaure, de cette obligation contractuelle est sanctionnée par une responsabilité de même nature, également contractuelle" (D 1936, p. 88 à 96, note signée "E.P", rapport Josserand et conclusions Matter).

${ }^{191}$ Les effets des obligations. Revue Trimestrielle de Droit Civil. Paris, t. 31, p. 724, 1932.

192 Obligations de résultat et obligations de moyens. Revue Trimestrielle de Droit Civil. Paris, t. 34, p. 499-543, 1935

${ }^{193}$ Le fondement de la responsabilité contractuelle rapproché de la responsabilité délictuelle. Revue Trimestrielle de Droit Civil. Paris, t. 32, p. 627-692, 1933.
} 
clínica médica haveria de ser responsabilizada civilmente pelas doenças que os pacientes tenham adquirido em suas salas de operação, desde que não demonstrasse a ausência de culpa sua. $^{194}$

Trata-se de uma espécie de obrigação de meio que, por força da inversão do ônus da prova, impõe ao devedor o ônus de comprovar ter agido diligentemente, respeitando todas as normas que regem sua arte ou ofício, a fim de evitar o dano ocorrido.

Mais uma vez nos, segundo nos parece, impõe-se notar que o subtipo apresentado pela Corte de Cassação neste caso advém da confusão que se nota no pensamente de Demogue, senão na doutrina francesa como um todo, ${ }^{195}$ acerca do significado do termo diligência, posto que confunde o conteúdo das obrigações de meio com a exigência de culpa como critério de imputação para responsabilização.

Talvez seja essa particular confusão que venha a permitir dizer que a distinção entre as obrigações de meio e de resultado na França tenha servido a um papel bastante diverso daquele que se nota na Alemanha e na Itália.

Parece que em solo francês a proposta de Demogue significou antes uma parte do processo de transição dos fundamentos que embasam a responsabilidade civil, com a gradativa derrocada da culpa, fenômeno que se nota no correr do século $\mathrm{XX},{ }^{196}$ que, efetivamente, como apresentação de um critério preciso e inovador dos limitas da inadimplência das prestações obrigacionais.

\footnotetext{
194 MINASSE, Elton. Contribuição ao estudo das obrigações “de meio" e de "resultado". 2005. Monografia (Mestrado) - Faculdade de Direito da Universidade de São Paulo, p. 66.

${ }^{195}$ MENGONI, Luigi . op. cit., p. 58

196 RIPERT, George. A regra Moral nas Obrigações Civis. Tradução de OLIVEIRA, Osório. São Paulo: Saraiva, 1937, p. 204 e ss.
} 


\section{A ESTRUTURA da RELAÇÃo JURÍDiCA OBRIGACIONAL.}

O estudo da relação jurídica obrigacional, embora não seja expressamente tem da pesquisa apresentada, tem larga utilidade na medida em que a distinção entre as obrigações de meios e de resultado versa diretamente sobre seu objeto, qual seja, a prestação.

A obrigação é o específico dever jurídico por força do qual a um sujeito, chamado devedor, impõe-se a realização de uma determinada prestação patrimonial no sentido de satisfazer o interesse de um outro sujeito, chamado credor. Além de designar a posição do devedor, o termo obrigação ainda indica o próprio vínculo que surge entre credor e devedor, vínculo este, por sua vez, definido como a relação tendo por objeto uma prestação patrimonial que um sujeito, dito devedor, deve executar no sentido de satisfazer o interesse de um sujeito, o credor. ${ }^{197}$

Pode-se compreender, ainda, a relação jurídica obrigacional, enquanto espécie de relação jurídica, ou seja, espécie de relação disciplinada pelo Direito, mediante uma atribuição a um determinado sujeito de um direito subjetivo, com a correspondente imposição a outrem de um dever ou uma sujeição. ${ }^{198}$

Assim, de modo analítico, esta relação jurídica em sentido estrito, é composta de um elemento subjetivo, um objetivo, um propulsor e um elemento de garantia.

O elemento pessoal pode ser definido como sendo o titular de um direito subjetivo e aquele sobre quem pesa e o onerado com o correspondente dever ou sujeição. Esses pólos podem ser ocupados por mais de um sujeito, sempre pessoas em sentido jurídico, já que dotadas de personalidade. ${ }^{199}$

O elemento objetivo é aquilo sobre o que incide o direito subjetivo, sobre o que incidem o poder ou poderes de que trata. Não é de se confundir, contudo, com o conteúdo da relação jurídica, vale dizer com as posições jurídicas ativa e passiva, tampouco com o conteúdo dos poderes formativos, as pretensões, faculdades e liberdades de que se vê dotado o sujeito ativo. O objeto das relações jurídicas será, portanto, a mesma coisa que o objeto de direitos. ${ }^{200}$

\footnotetext{
${ }^{197}$ BIANCA, C. Massimo. op. cit., p. 1-3.

198 ANDRADE, Manuel A. Domingues de. Teoria Geral da Relação Jurídica. Coimbra: Almedina, 1983, $6^{\mathrm{a}}$ ed., v. I, p. 2.

${ }^{199}$ ANDRADE, Manuel A. Domingues de. op. cit., p. 19.

${ }^{200}$ ANDRADE, Manuel A. Domingues de. op. cit., p. 20.
} 
Propulsivo é o fato jurídico, enquanto elemento suficiente para produzir consequências jurídicas, embora nem todos os fatos jurídicos sejam suficientes para gerar relações jurídicas, é o caso dos fatos jurídicos extintivos, cuja função precípua é precisamente dar cabo de relações jurídicas. ${ }^{201}$

Por fim a garantia é o poder do sujeito ativo exigir da outra parte um determinado comportamento, um facere ou non facere. Trata-se do conjunto de meios sancionatórios que adota o Estado, por intermédio de seus tribunais, contra o sujeito passivo que furta-se ao cumprimento espontâneo de seu dever jurídico. ${ }^{202}$

Nesse quadro que se vem de demonstrar, quer nos parecer que elemento de maior importância e principal para a o estudo que ora se apresenta é, certamente, o objeto da relação jurídica.

O objeto de um direito subjetivo é precisamente aquilo sobre o que recai o poder ou poderes encerrados na relação jurídica obrigacional. $\mathrm{O}$ direito subjetivo pode ser concebido como a faculdade de uma pessoa, concedida pela ordem jurídica, à satisfação de um interesse mediante o sacrifício do interesse contrário do sujeito passivo.

Diante disso, é de se compreender que o objeto da relação jurídica pode ser imediato, na medida em que se trate daquilo sobre o que os respectivos poderes incidem diretamente (caso dos direitos reais, que se exercem diretamente sobre a coisa), ou mediatos, como é comum no direito das obrigações, onde o objeto imediato do direito do credor é a prestação do devedor ou, de acordo com alguns teóricos, o próprio sujeito do devedor, ao passo que mediato seria a própria coisa que se espera perceber por meio da prestação. $^{203}$

Neste ponto é de se notar a grave importância que tem a análise da prestação, objeto da relação jurídica obrigacional, numa classificação que se pretende do conteúdo das obrigações.

${ }^{201}$ PONTES DE MIRANDA, Francisco Cavalcanti. Tratado de Direito Privado. Rio de Janeiro: Borsoi, $3^{\text {a }}$ ed., 1970, v. I, p. 77.

${ }^{202}$ ANDRADE, Manuel A. Domingues de. op. cit., p. 22 e ss.

${ }^{203}$ ANDRADE, Manuel A. Domingues de. op. cit., p. 190. 


\subsection{OS ELEMENTOS DO VÍNCULO OBRIGACIONAL.}

Entre os elementos do vínculo obrigacional ligam-se às duas posições subjetivas correlativas ao débito e ao crédito, a prestação e o interessa que a prestação deve satisfazer.

Assim, o débito é a posição jurídica passiva do vínculo obrigacional, comumente indicada com o próprio termo obrigação.

Este débito enquadra-se na categoria do dever jurídico, designando-se, no geral, como se viu, uma posição jurídica de necessidade imposta ao sujeito no sentido da satisfação do interesse de outrem. De forma que a obrigação se caracteriza como dever específico de conteúdo patrimonial.

A obrigação se caracteriza particularmente como dever de conteúdo patrimonial. A obrigação se caracteriza pois como dever específico, ou seja como dever no confronto de dois sujeitos para a satisfação de interesses individuais. Diante deste delineamento, a obrigação distingue-se dos demais deveres genéricos, que interessam à vida das relações, ou seja, os deveres que o ordenamento impõe diante da generalidade das relações (dever de respeito à pessoa, dever de respeito aos bens de outrem, ecc.) (tradução livre). ${ }^{204}$

Não é demais, nesse ponto, dizer que o interesse que o credor tem no cumprimento da prestação pode deixar de ser patrimonial, pode ele ser moral ou afetivo, bastando que seja lícito para que se constitua um vínculo obrigacional, isso não quer dizer, entretanto, que a prestação a ser entregue possa deixar de ter conteúdo econômico, posto que do contrário jamais poderia recair sobre o patrimônio do devedor por força de inadimplemento. ${ }^{205}$

À idéia de débito é de se ligar à de responsabilidade pessoal e patrimonial do devedor. O direito não se limita a impor um dever de prestar ao obrigado, procura assegurar também assegurar a realização coativa da prestação, sem prejuízo do direito que, em certos casos, cabe ao credor de resolver o contrato ou de recusar legitimamente o cumprimento da obrigação que recai sobre ele próprio.

\footnotetext{
204 “L'obbligazione si caratterizza particolarmente come dovere a contenuto patrimoniale. L'obbligazione si caraterizza poi come dovere specifico, ossia come dovere nei confronti di determinati soggetti per il soddisfacimento di interessi individuali. Stto questo profilo l'obbligazione si distingue quindi rispetto ai doveri generici, che interessano la vita di relazione, ossia ai doveri che l'orinamento impone nei confronti della generalità dei consociati” (BIANCA, C. Massimo. op. cit., p. 22).

${ }^{205}$ RUGGIERO, Roberto. op. cit., p. 28.
} 
A responsabilização ou garantia pessoal implica a sujeição do devedor à sanção contra o descumprimento obrigacional, especialmente, à imposição de ressarcimento dos danos provocados.

Em sua feição patrimonial e vista do lado do devedor, a garantia traduz-se fundamentalmente na persecução de seu patrimônio pelo cumprimento da obrigação, uma consequente sujeição dos bens que o integram aos fins da execução forçada. ${ }^{206}$

Dentro dos estreitos limites deste trabalho, é oportuno lembrar que a teoria da responsabilidade patrimonial do devedor não é pacificamente aceita, na medida em que diversos autores apresentam fortes objeções à teoria da obrigação como relação complexa, integrada entre os elementos débito (Shuld) e responsabilidade (Haftung). Onde o primeiro consiste no dever de prestar, o segundo, na sujeição dos bens do devedor ou de terceiro à execução coativa.

Basta lembrar que a teoria da relação complexa integrada do débito e da responsabilidade consideram tais posições não só distintas, mas cindíveis. O que acabou por levar a concepção de débito a um posicionamento marginal, eclipsado pela força da garantia patrimonial, mitigando o valor e interesse na prestação mesma, deixada de lado pela possibilidade de obtenção o equivalente patrimonial.

Limitando praticamente todos os efeitos jurídicos da primária relação de débito à exclusão da condictio indebiti, por parte do devedor, e à solutio retentio, por banda do credor, os autores reduziram a posição deste a um simples expectativa ou a um estado de confiança (fiducia) jurídica, e a do devedor a um simples estado de pressão psicológica, a uma pura necessidade moral ou racional, ou a um dever livre, na terminologia paradoxal de Brunetti. ${ }^{207}$

Dito isso, uma concepção unitária da obrigação, a visão da relação obrigacional capaz de retratar sua unidade ontológica, não mitigando o valor da atividade do devedor como objeto do débito e do crédito.

O crédito, por sua vez, é de ser compreendido como o direito ao adimplemento, ou seja, o direito do credor à execução da prestação devida. Trata-se de um pretensão jurídica, uma posição de expectativa jurídica contraposta a um dever correlativo.

O objeto ou conteúdo do vínculo obrigatório é a prestação, ou seja, aquilo que é devido do credor ao devedor. Pode ela consistir na realização de qualquer finalidade que seja, desde que lícita, desde que imputável ao devedor.

\footnotetext{
${ }^{206}$ VARELA, João de Matos Antunes. Das Obrigações em Geral. Coimbra: Almedina, 10ª ed., 2000, p. 130.

${ }^{207}$ VARELA, João de Matos Antunes. op. cit., p. 152.
} 
Desta forma, enquanto o objeto do vínculo obrigacional é a prestação, esta é objeto da correlação entre a posição de débito e crédito. Isto é, aquilo a que o devedor é obrigado é, precisamente, uma determinada prestação. É a essa precisa prestação, por sua vez, que tem direito ao credor, é ela o objeto de sua pretensão juridicamente protegida (crédito). ${ }^{208}$

Essa conclusão vem demonstrar a necessidade de se empreender um breve estudo da prestação obrigacional.

${ }^{208}$ BIANCA, C. Massimo. op. cit., p. 32-33. 


\subsection{A PRESTAÇÃO.}

O objeto ou conteúdo da obrigação, como já se teve oportunidade de dizer, é a prestação. A sua realização é o fim a que se destina a relação jurídica obrigacional, não sendo por outro motivo que se constitui em modo natural de extinção das obrigações.

Deve ser compreendida como atividade ou ação que o devedor ou obtenção de um determinado resultado prático, de acordo com os diversos conteúdos que pode assumir.

As teorias que analisam a prestação obrigacional costumam dividir-se em dois grupos principais, o da prestação subjetiva e da prestação objetiva.

Segundo a primeira tese, mais tradicional, a prestação tem caráter essencialmente subjetivo, ela se consiste puramente num comportamento do credor. Trata-se de posição de tradição romanística fundada na idéia de que o objeto da obrigação é uma atividade que o devedor deve desenvolver para satisfação do interesse do credor e tem suas raízes em fragmento de Paulo (D.44.7.3 pr.) "obligationem substantia non in eo consistit, est aliquod corpus nostrum aut servitutem mostram faciat, sed ut alium nobis obstringat ad dandum aliquid vel faciendum vel praestandum". ${ }^{209}$

Essa tese ganha força na idéia de que o devedor pode ser obrigado apenas nos limites de seu agir e nos limites de seu comportamento. Assim, ainda que um resultado fosse devido, seria ele fruto de uma atividade do devedor, seria ele fruto do momento conclusivo de seu agir.

Contudo, resta a teoria subjetivista com sérias dificuldades para explicar certas situações em que o resultado obtido pelo devedor não encontra origem num comportamento ou atividade do devedor, como seria o caso do locador que se obriga a garantir a pacífica utilização da coisa locada pelo locatário (não há aqui um fazer ou deixar de fazer do devedor vinculado à satisfação do credor, tão somente um resultado específico e determinado); ou as prestações de dar, que acabam reduzidas a um à oferta de bem ao credor. $^{210}$

As teorias objetivas, por sua vez, consideram o centro do problema o resultado produzido, relegando a segundo plano o comportamento do devedor. Nesses termos, o

\footnotetext{
${ }^{209}$ RUGGIERO, Roberto de. op. cit., p. 19.

${ }^{210}$ BIANCA, C. Massimo. op. cit., p. 70.
} 
resultado procurado é a própria prestação devida, seja ele uma situação determinada, fruto da atuação do devedor, seja a satisfação do interesse do credor.

Ocorre que a noção de prestação ligada à satisfação do interesse do credor não pode jamais ser levada a atermos absolutos, pois acolheria uma série de situações em que o interesse do credor é atendido de maneira acidental e independentemente da atuação do devedor, o que tornaria seu comportamento absolutamente desnecessário, até mesmo decorativo. Além disso, a noção de prestação enquanto situação final do vínculo obrigacional não é exauriente, sendo este apenas um dos modos de realização da prestação.

Outro posicionamento pode-se encontrar no pensamento de Von Tuhr, que considera a prestação como sendo o ato do devedor capaz de transfigurar-se num benefício específico para o credor, comumente verificado na produção de uma utilidade material posta à sua disposição. $^{211}$

De se lembrar, ainda, o posicionamento de Betti, que diante do chama de crise moderna da cooperação, enxerga na prestação obrigacional um momento subjetivo, ligado ao "comportamento de cooperação exigido do devedor" e um momento objetivo, que se liga à utilidade que a prestação apresenta para o credor. ${ }^{212}$

Por fim, autorizada doutrina versou sobre a importância de se distinguir e de cindir dois dos elementos dos quais resulta o vínculo obrigacional, o crédito e o comportamento devido. Respeitados estes termos, o objeto do direito do credor seria, de fato, não o comportamento do devedor, mas o bem, a coisa ou utilidade que se visa alcançar por meio do cumprimento regular da obrigação e que se constitui, geralmente, num resultado da atividade do devedor, sem que se impeça seja obtido por fato diverso. Por outro lado, objeto do comportamento obrigatório seria não o bem devido, mas a atividade que, em regra, é o meio idôneo para a obtenção do resultado esperado pelo credor. ${ }^{213}$

Essa tese parece buscar mediar as duas posições tradicionais e opostas, a teoria patrimonial da prestação e a teoria subjetiva da prestação obrigacional.

Contudo, é apenas aparente a oposição teórica que qualquer tese acerca do conteúdo da prestação obrigacional apresenta à distinção das obrigações de meios das de resultado.

A distinção ora analisada não se funda sobre a discussão do conteúdo da prestação, antes a pressupõe como forma de fixar os limites do inadimplemento.

\footnotetext{
${ }^{211}$ Tratado de las obligaciones. Tradução de ROCES, W. Madrid: Editorial Reus, 1934, v. I, p. 33.

${ }^{212}$ Teoria Generale dele obbligazioni. op. cit., p. 39.

213 D'AMICO, Giovanni. op. cit., p. 162-163.
} 
É absolutamente evidente que no âmbito das teorias aqui apresentadas, se o objeto da obrigação é um comportamento do devedor ou se é um bem devido (resultado útil que um comportamento do devedor tenha produzido para o credor), se colocam todas as relações jurídicas obrigacionais. Isso porque todas as obrigações, não só as de meios como as de resultado, têm por objeto "um comportamento pessoal do obrigado", se se aceita o postulado das teorias subjetivas, ou o resultado útil alcançado para o credor, direta ou indiretamente, pelo comportamento do devedor.

Assim, se considerarmos a prestação obrigacional como um resultado (prestaçãoresultado) produzido pelo comportamento do devedor, sendo, portanto, objeto da relação obrigacional, poderemos concluir que, nas obrigações de resultado, prestação-resultado e o resultado a que se refere a obrigação são convergentes. Entretanto, no caso das obrigações de meios, teríamos um que o resultado ou bem devido, objeto da prestação-resultado, não se casa integral e necessariamente com a satisfação do interesse do credor (resultado este que se pode chamar extrínseco). Isso porque o resultado extrínseco (bem ou utilidade capaz de satisfazer o interesse do credor), se é conteúdo da prestação, não é devido em no vínculo obrigacional, mas não em absoluto, apenas na medida em que possa ser alcançado por uma atividade diligente (perita, prudente) do devedor. ${ }^{214}$

Aliás, não é demais lembrar, a propósito, que existem resultados que podem ser previstos e programados, enquanto consequências determinadas e certas, ao menos abstratamente, de uma atividade, e resultados que, diferentemente, não podem ser previstos a priori ou não decorrem como certos de um comportamento especificamente considerado.

${ }^{214}$ D’AMICO, Giovanni. op. cit., p. 171-172. 


\section{O TRATAMENTO DA DISTINÇÃO DO DIREITO ATUAL.}

\subsection{O DIREITO FRANCÊS.}

A expressão forjada por Demogue em seu Traité é capaz de transparecer a urgência que movia seu estudo e as razões de fundo que animavam sua proposta teórica.

O civilista francês compreende obrigação como o comportamento que o devedor assume principalmente no plano técnico profissional. ${ }^{215}$ Os meios devidos seriam, essencialmente, medida técnicas por meio das quais os donos de indústria resguardavam a saúde de seus operários, a companhia de transporte protege seus passageiros, o médico tutela seus pacientes. ${ }^{216}$

É de se dizer que era bastante grave a crise do trabalho à época em que Demogue redigia seu Traité, na medida em que à disseminação vertiginosa de fábricas não seguia a jurisprudência com condições técnicas de resolver os crescentes reclamos de indenização por acidentes de trabalho, posto que ainda presa à exigência da demonstração de culpa, quando não à tese delitual. ${ }^{217}$ Além disso, não se pode olvidar a crise similar por que passavam os tribunais na tentativa de dar solução aos incontáveis casos de acidentes de transporte diante, tendo enormemente contribuído divulgação da teoria das obrigações de garantia a distinção das obrigações de meios das de resultado. ${ }^{218}$

O posicionamento de Demogue quanto a estas questões parece denunciar uma tentativa do autor de mediar os reclamos de maior liberdade de uma classe de devedores que traziam o progresso (industriais, profissionais liberais, transportadoras) e a necessidade de se assegurar uma gama bastante ampla de pessoas ávidas para disfrutar do progresso técnico, entretanto gravemente sujeitas aos riscos que ele trazia. ${ }^{219}$

“As obrigações existem para dar satisfação aos credores na medida em que não seja inconciliável com o interesse dos devedores", 220 dizia o civilista francês sem eu Traité,

${ }^{215}$ DEMOGUE, René. Professionisti e non professionisti nel dirito civile. apud CARBONE, Enrico, op. cit., p. 12.

${ }^{216}$ DEMOGUE, René. Traité..., op. cit., p. 539 e ss.

${ }^{217}$ REMY, Philippe. op. cit., p. 331.

${ }^{218}$ BELISSENT, Jean. op. cit., p. 253.

${ }^{219}$ CARBONE, Enrico. op. cit., p. 12.

220 "Les obligation existent pour donner satisfaction aux créanciers dans une mesure qui ne soit pas inconciliable avec l'intérêt des débiteurs" (DEMOGUE, René. Traité..., op. cit., v. I, p. 18). 
lógica essa que perpassa a obra e parece conduzir à criação de um juízo de diligência técnica não particularmente gravoso para o agente.

O particular ângulo de observação do qual a distinção vem formulada - aquele da repartição do ônus da prova no juízo de responsabilidade - parece conforme à estreita correlação com o problema do progresso tecnológico, cujo principal reflexo na controle da imputação começa a manifestar-se na dificuldade de reconstruir um mecanismo causal, subitamente fragmentado e obscuro, e na incapacidade dos clássicos métodos demonstrativos diante dos danos destinados a permanecerem, sempre em maior número, anônimos (tradução livre). ${ }^{221}$

A solicitude de Demogue com o tema da prova já podia, marcada pela preocupação de elaboração de um direito civil ligado ao dinamismo social, ser notada em dois de seus trabalhos anteriores ao Traité. 222

Quer nos parecer, entretanto, que foi por advogar a unidade parcial da responsabilidade civil, ${ }^{223}$ com a consequente extensão de sua proposta teórica para o terreno delitual, que Demogue ganhou seu maior partidário.

Partidário da opinião de que uma classificação baseada sob a fonte das obrigações seria útil apenas para governar as questões inerentes ao perfil originário das obrigações e uma vez que surgido o vínculo obrigacional uma classificação presa à gênese não poderia resolver as questões de aplicação da culpa ou de distribuição do ônus da prova, Mazeud propõe a adoção de um sistema classificatório centrado no conteúdo mesmo das obrigações. $^{224}$

Entretanto, em que pese acolhida fervorosa de Mazeud e de outros tantos autores, a classificação de Demogue recebeu duras críticas.

Segundo alguns opositores, a distinção proposta basear-se-ia numa falsa visão da realidade, na medida em que dificilmente seria possível conseguir-se uma divisão precisa e radical entre as obrigações de meios e as de resultado.

O caso da responsabilidade civil do médico, como nos diz Paul Esmein, embora apresentado como tipicamente de meios, seria em verdade de resultado, isso porque, tendo ele feito uma cirurgia, ainda que tivesse cometido os mais graves e absurdos erros no

\footnotetext{
221 “Il particulare angolo d'osservazione dal quale la distinzione venne formulata - mello della ripartizione dell'onere della prova nel giudizio di responsabilità - sembra confermarne la stretta correlazione con $i$ problemi del progresso tecnologico, il cui principale riflesso negli accertamenti di imputazione cominciava a manifestarsi nella difficoltà di ricostruire $i$ meccanismi causali, sovente frammentati ed oscuri, e nell'incapacità dei classici metodi dimostrativi al cospetto di danni destinati a rimanere, sempre più spesso, anonime" (CARBONE, Enrico. op. cit., p. 13).

${ }^{222}$ La preuve. In Les notions fondamentales du droit privé. Essai critique. Paris, 1911, p. 542 e ss. e De la preuve de la faute lourde en cas de perte d'un colis postal. apud CARBONE, Enrico. op. cit., p. 13.

${ }^{223}$ DEMOGUE, René. Traité des Obligations en Général. op. cit., v. V, p. 525.

${ }^{224}$ MAZEUD, Henri. Essai de classification des obligations. op. cit., p. 5 e ss. e 22 e ss.
} 
correr da intervenção, jamais seria responsável se tivesse logrado curar seu paciente ao final, ainda que por acaso. ${ }^{225}$

Por outro lado, Wigny ${ }^{226}$ e Marton $^{227}$ acreditavam que todas as obrigações seriam de resultado, o que certamente podemos objetar com base no que resta dito no capítulo precedente.

Além disso, alguns autores, por força da ampla diversidade de obrigações que encerravam cada um dos tipos classificatórios, muitos autores foram levados a acreditar que tratar-se-ia de uma proposta classificatória absolutamente arbitrária ou, ao menos, reducionista, na medida em que fecha os olhos para particularidades importantes das diferentes espécies obrigacionais. ${ }^{228}$

Alguns autores chegaram, aproximando a classificação apresentada da distinção entre a responsabilidade objetiva e subjetiva, questionar a validade da distinção, ora com base em casos em que rejeitavam a solução objetiva, ${ }^{229}$ ora por acreditarem que deveria ela ser afastada em favor da responsabilidade civil que preconizam. ${ }^{230}$

Contudo, em que pesem as constantes objeções em contrário, parte respeitável da doutrina acabou por acolher a classificação proposta, largamente adotada pelos tribunais franceses. $^{231}$

Aliás, quanto é isso, pode-se sentir nos tribunais franceses, inclusive uma tendência no sentido de criar graduações nas obrigações de meios, por exemplo, considerando-se menos extensas nos casos de mandato ou depósito gratuito. Noutras hipóteses, como do exercício de atividade profissional, as obrigações de meios são consideradas mais rígidas, chegando mesmo a jurisprudência a propor a hipótese de obrigações de meios reforçadas, que em muito se aproximam das obrigações de resultado, para o caso de empréstimo quando o devedor, sendo forçado a salvar as coisas suas ou as do credor, preferir as primeiras. $^{232}$

\footnotetext{
${ }^{225}$ ESMEIN, Paul. Le fondement de la responsabilité contractuelle raprochée de la responsabilité délictuelle. in Revue Trimestrielle de Droit Civil. Paris, t. 32, 1933, p. 658.

${ }^{226}$ WIGNY, P. Responsabilité contractuelle et force majeure. in Revue Trimestrielle de Droit Civil. Paris, t. 34, 1935, p. 48.

${ }^{227}$ MARTON, G. Obligations de résultat et obligations de moyens. in Revue Trimestrielle de Droit Civil. Paris, t. 34, 1935, p. 499.

${ }^{228}$ SATRCK, Boris. Domaine et fondement de la responsabilité sans faute. in Revue Trimestrielle de Droit Civil. Paris, t. LVI, 1958, p. 499.

${ }^{229}$ ESMEIN, Paul. op. cit., p. 633.

${ }^{230}$ MARTON, G. op. cit., p. 489.

${ }^{231}$ VINEY, Geneviève. op. cit., p. 448.

${ }^{232}$ VINEY, Geneviève. op. cit., p. 451-453.
} 
Ressalta-se, ainda, que mesmo as obrigações de resultada têm graduações segundo a jurisprudência francesa, como nos casos de locação, em que o locatário se exonera de ressarcir os prejuízos sofridos se provar que não agiu com culpa, ou nos casos de transporte marítimo, em que igualmente se admite a prova de ausência de culpa. É de se notar, aqui, que a obrigação tipo de resultado passaria a ser, em verdade, de meios, presumindo-se apenas a culpa de um dos sujeitos. ${ }^{233}$

Nesse quadro, é de notar que Philippe le Tourneau realiza prolífera análise das obrigações de resultado, apresentado, inclusive, um elenco de critérios que a doutrina e a jurisprudência têm adotado para a distinção entre as obrigações de meios e de resultado.

O primeiro deles seria o critério da álea.

Nesse caso, as obrigações de resultado não poderiam ser explicadas senão nos casos em que a obtenção do resultado é normalmente possível e esperado pela execução do comportamento obrigatório.

O resultado prometido aparece como suficientemente certo para se constituir em objeto da obrigação de resultado, a álea deixa de existir na medida em que o devedor pode colocar sobre seu controle coisa, fatos e pessoas, colocados sob sua guarda. Entretanto, não se pode confundir a álea, neste ponto, com aquela existente nos contratos aleatórios. Neste último caso, o risco ataca a própria existência da obrigação (pagar ou não a indenização pela ocorrência do sinistro no contrato de seguro), a álea que se analisa não afasta a possibilidade de ocorrência do resultado esperado de maneira definitiva, apenas faz com que a conduta do devedor possa não ser suficiente para transformá-lo em realidade, caso em que se teriam as obrigações de meios. ${ }^{234}$

Podem ser considerados exemplos típicos da aplicação deste critério de distinção a obrigação do médico e do transportador, a primeira de meios, a segunda, de resultado.

Um outro critério comumente adotado é o do papel da vítima na execução do contrato. Nestes termos, desde que o credor em grande medida livre para conduzir seus movimentos, independente para formas suas convicções, estaríamos diante de uma obrigação e meios, por outro lado, se a vítima permanece absolutamente passiva e deixa-se levar, confiando nos desígnios do devedor, haveria obrigação de resultado. ${ }^{235}$

Este critério é enormemente falho, na medida não só cria condições para que contratos similares tenham soluções diversas, de acordo com o comportamento adotado

\footnotetext{
${ }^{233}$ VINEY, Geneviève. op. cit., p. 454-455.

${ }^{234}$ TOURNEAU, Philippe le. op. cit., p. 919.

${ }^{235}$ TOURNEAU, Philippe le. op. cit., p. 919.
} 
pela vítima, como imporia ao médico sempre obrigações de resultado, pois em que situações seria a vítima dotada de maior passividade que quando deixa seu próprio corpo aos cuidados de outrem?

É de se ressaltar, entretanto, que como forma de solucionar essa questão, a jurisprudência tem o entendimento de que a aceitação do risco pela vítima afasta a existência de obrigações de resultado. Assim, o paciente que, ainda que tacitamente, viesse se apresentar de maneira absolutamente passiva diante do médico, seria credor apenas de uma obrigação de meios. ${ }^{236}$

Em que pese o critério do papel da vítima apresentar utilidade na distinção, é de se esclarecer que se trata de uma outra forma de adoção do critério da álea, pois a participação ativa do devedor aumenta o risco do credor, cuja atividade passa a depender, além dos fatores comuns, do comportamento de outrem. De outra parte, a idéia de aceitação do risco por parte do credor parece sinalizar no sentido de que exista de fato um risco, seja ele real e ligado à atividade exercida, seja ele fruto da atuação do credor. ${ }^{237}$

Nesse ponto é de grande importância mencionar o Avant-Projet de Reforme $d u$ Droit Des Obligations traz cristalina definição das diferentes espécies de obrigações conforme a clássica lição de que o devedor de uma obrigação e resultado é obrigado, ressalvado o caso fortuito ou de força maior, a procurar proporcionar ao credor a utilidade prometida, por outro lado, o devedor das obrigações de meios obriga-se apenas a conduzirse de maneira normalmente idônea para alcançar o objetivo prometido, subordinando-se a sua responsabilização à prova de tenha agido com falta de prudência e diligência.

Transcrevemos o dispositivo que trata da matéria.

Art. 1149 A obrigação é dita de resultado quando o devedor é obrigado, salvo em caso de força maior, a proporcionar ao credor a satisfação prometida, de tal sorte que, ressalvado aquele caso, sua responsabilidade surge do só fato de que tenha ele obtido sucesso em atender ao fim fixado.

A obrigação é dita de meios quando o devedor é apenas obrigado a adotar os cuidados e diligência normalmente necessários para atender a um certo fim, de tal sorte que a sua responsabilidade se subordina à prova de que tenha ele faltado com prudência ou diligência (tradução livre). ${ }^{238}$

\footnotetext{
${ }^{236}$ TOURNEAU, Philippe le. op. cit., p. 919.

${ }^{237}$ TOURNEAU, Philippe le. op. cit., p. 922.

238 “Art. 1149 L'obligation est dite de résultat lorsque le débiteur est tenu, sauf cas de force majeure, de procurer au créancier la satisfaction promise, de telle sorte que, ce cas excepté, sa responsabilité est engagée du seul fait qu'il n'a pas réussi à atteindre le but fixé.

L'obligation est dite de moyens lorsque le débiteur est seulement tenu d'apporter les soins et diligences normalement nécessaires pour atteindre un certain but, de telle sorte que sa responsabilité est subordonnée à la preuve qu'il a manqué de prudence ou de diligence”.
} 
É de se notar que, na medida em que as partes geralmente deixam de especificar o conteúdo da obrigação que assumem, o projeto Catala preferiu redigir-se por vocábulos diretivos, capazes de suprimir as controvérsias que reinariam por força do silencia das partes.

Entretanto, segundo nos parece, pouco fez para resolver o problema de distinção das obrigações ora analisadas, na medida adota, sequer sugere, um critério de distinção, como a álea ou a conduta do devedor, de forma que, ainda que diante de tais dispositivos, ousamos dizer que a controvérsia terá pouco ou nenhuma alteração. 


\subsection{O DiReito ItALiano.}

Osti antecipou em muito a apresentação da distinção entre obrigações de meios e de resultado, o que somente se fez quase uma década mais tarde na França.

O autor italiano, ao dividir as obrigações em duas categorias, as de dever de uma determinada diligência, e as de um dever de se atingir um determinado resultado presou, em sua pureza dogmática, pela idéia de uma potencial equivalência entre as duas categorias propostas e um modelo binário de responsabilidade civil, assim, as obrigações de meios seriam regidas pela responsabilidade fundada na culpa, enquanto as obrigações de resultado seriam conduzidas pela responsabilidade objetiva.

O imponente esforço dogmático de Osti, empenhado na reafirmação da natureza objetiva da responsabilidade contratual, tinha necessidade da bipartição entre obrigações de resultado e obrigações de meios, assim poderia conseguir um certo equilíbrio teórico, que uma preocupação excessivamente objetivista acabaria por comprometer.

Isso se torna claro quando notamos que a obrigação de diligência, conforme proposta por Osti, ao final tem resguardado um campo extremamente tímido, ${ }^{239}$ o que torna dominante a obrigação de resultado e, consequentemente, a aplicação de um modelo de responsabilidade objetivo.

Mais tarde, diante da polêmica surgida acerca dos artigos 1.176 e 1.218 do Código Civil italiano, ${ }^{240}$ Giorgianni ${ }^{241}$ e Betti ${ }^{242}$ se posicionariam no sentido de que, o primeiro artigo, tendo sua origem no direito francês em disposição que trata do depósito e do empréstimo, igualmente estaria restrito a estas espécies contratuais, então consideradas como capazes de gerar obrigações de meio para o devedor.

\footnotetext{
${ }^{239}$ OSTI, Giuseppe. op. cit., p. 425.

${ }^{240} \mathrm{O}$ art. 1.176 afirma que o devedor deve, no cumprimento de suas obrigações, adotar a diligência do bônus pater famílias, sendo que nos casos de prestação de serviços profissionais, os limites da diligência serão analisados de acordo coma a atividade realizada (Art. 1176 Diligenza nell'adempimento. Nell'adempiere l'obbligazione il debitore deve usare la diligenza del buon padre di famiglia. Nell'adempimento delle obbligazioni inerenti all'esercizio di un'attività professionale la diligenza deve valutarsi con riguardo alla natura dell'attività esercitata) o art. 1.218 afirma que o devedor que não executa a obrgiação devida torna-se obrigada a ressarcir os danos causados, salvo se provar que o inadimplemento é fruto da impossibilidade jurídica da prestação que não lhe seja imputável (Art. 1218 Responsabilità del debitore. Il debitore che non esegue esattamente $(1307,1453)$ la prestazione dovuta è tenuto al risarcimento del danno $(2740)$, se non prova $(1673,1681,1693,1784,1787,1805-2,1821)$ che l'inadempimento o il ritardo è stato determinato da impossibilità della prestazione derivante da causa a lui non imputabile).

${ }^{241}$ D’AMICO, Giovanni. op. cit., p. 111.

242 op. cit., p. 128.
} 
Nestes termos é que se insere a problemática das obrigações de meios e de resultado na doutrina italiana, que se interessa mais com a capacidade que tem de descrever o conteúdo das obrigações que, propriamente na capacidade que possui de organizar o ônus da prova ou, como comumente se nota numa referência imprudente e inadequada, estabelecer diversas ordens de responsabilidade.

Assim passa a se preocupar com o significado e extensão do termo diligência, incialmente considerado predicado ordinário da normalidade e da meditação. ${ }^{243}$

O parâmetro valorativo da diligência mencionada do bonus pater familias, embora controverso, é de ser considerado como mero sinônimo de lícito, reflexo da regularidade da conduta, no que se pode dizer tratar-se do parâmetro da aurea mediocritas.

${ }^{243}$ CARBONE, Enrico. op. cit., p. 79. 


\section{Conclusões.}

A distinção que ora se analisa não abarca todas as espécies obrigacionais, restringindo-se antes àquelas em cujo pólo passivo se encontra um dever jurídico comportamental.

Interessa ao estudo das obrigações de meios e de resultado os conceitos de prestação e de relação jurídica obrigacional, fundamentas para a própria formulação da classificação.

Contudo, nota-se que se de um lado é de grave importância o conceito de prestação e a análise de seus conteúdo, a classificação ora em análise prescinde de um particular posicionamento teórico acerca do objeto da obrigação ou do conteúdo da prestação, no sentido de que pouco importa que se considere a prestação um determinado bem ou utilidade a ser produzida para o credor (prestação objetiva), ou que se lhe atribua o conteúdo da atividade do devedor.

Ainda assim, sendo as partes livres para determinar, nos limites do ordenamento jurídico, o conteúdos dos respectivos negócios, os efeitos identificam-se, na parte autônoma das determinações negociais, com o interesse das partes deduzido.

Além disso e na medida em que trata a classificação de uma análise do conteúdo da prestação, o campo próprio da distinção é o das obrigações de fazer. Isso se explica pois as obrigações de dar, sejam elas de transferência do direito de propriedade, constituir algum direito real, ou transferir a posse, são sempre caracterizadas por um resultado (a efetiva transferência da posse, da propriedade, o que as tornam sempre espécies de obrigações de resultado. $^{244}$

O facere abrange toda a espécie de prestações positivas, sendo categoria do qual participam o fazer em senso estrito e o dar em sentido estrido.

O fazer em sentido estrito engloba os atos de ordem física stricto sensu e os atos de ordem psíquica, o fazer em sentido lato, a dação de objetos. ${ }^{245}$ As prestações de atos pessoais seriam aquelas de atuação focada num ato do devedor e que não se reduzam a um prestação de objeto, por outro lado, as prestações de objeto englobam prestar qualquer objeto existente.

\footnotetext{
${ }^{244}$ MINASSE, Elton. op. cit., p. 90.

${ }^{245}$ PONTES DE MIRANDA, Francisco Cavalcante. op. cit., v. XXII, p. 74.
} 
Os tipos de comportamento descritos, entretanto, não se excluem mutuamente, não sendo impossível que a um só tempo uma prestação de objeto envolva um ato de ordem física ou psíquica, ou vice versa. Em vindo isso a ocorrer, as prestação podem manter entre si grau de complementariedade, permanecendo independentes, ou de dependência, uma das prestações polariza a outra.

Por fim, embora seja digna de nota a opinião de Philippe le Tourneau no sentido de que a distinção entre obrigações de meios e de resultado sejam somente aplicáveis ao campo contratual, ${ }^{246}$ que nos parecer que devam aplicar-se a todas as modalidades de obrigação caracterizadas por um facere. Aliás, não é de se olvidar o fato de que muitos autores propõem, inclusive, uma aplicação mais ampla que essa. ${ }^{247}$

${ }^{246}$ op. cit., p. 907.

${ }^{247}$ OSTI, Giuseppe. op. cit., p. 124 e ss. MAZEUD, op. cit. 


\section{BibliOgRAFIA.}

ALBERTARIO, Emilio. Le definizione dell'obbligazioni romana. in Studi di Diritto Romano. Milano: Giuffrè, 1936, v. 3.

ALVES, José Carlos Moreira. Direito Romano. Rio de Janeiro: Forense, 14 ${ }^{\mathrm{a}}$ ed., 2008.

ANDRADE, Manuel A. Domingues de. Teoria Geral da Relação Jurídica. Coimbra: Almedina, 1983, $6^{\text {a }}$ ed., v. I.

ARANGIO-RUIZ, Vincenzo. Istituzioni di Diritto Romano. Napoli: Casa Editrice Dott. Eugenio Jovene, 2006.

ARISTÓTELES. Metafísica. Tradução de VALLANDRO, Leonel. Porto Alegre: Editora Globo, 1969.

A Ética. Tradução de FONSECA, Cássio M. São Paulo: Atena Editora, 1950.

BELISSENT, Jean. Contribution à l'analyse de La distinction des obligations de moyens et des obligations de résultat à propos de l'évolution des ordres de responsabilité civile. Paris: L.G.D.J, 2001.

BETTI, Emilio. Teoria Generale delle Obbligazioni. Milano: Giouffrè, 1953, v. I.

BIONDI, Biondo. Istituzioni di Diritto Romano. Milano: Giuffrè, 1972.

BIANCA, C. Massimo. Diritto Civile. Milano: Giuffrè, 1993, v. IV.

BUZAID, Alfredo. Do Concurso de Credores no Processo de Execução. São Paulo: Saraiva, 1952.

CARBONE, Enrico. Diligenza e risultato. Torino: Giappichelli, 2007.

CHAVES, Antonio. Força Maior. in Enciclopédia Saraiva do Direito. Coordenação de Rubens Limongi França. São Paulo: Saraiva, v. 38, p. 148-159.

CORREIA, Alexandre, SCIASCIA, Gaetano. Manual de direito Romano. Rio de Janeiro: Livros Cadernos Ltda. Guanabara, Série "Cadernos Didáticos". 
D’AMICO, Giovanni. La responsabilità ex recepto e la distinzione tra obbligazioni “di mezzi" e "di risultato" - contributo alla teoria della responsabilità contrattuale. Napoli: Edizioni Scientifiche Italiane, 1999.

DEMOGUE, René. Traité des Obligations en Général. Paris: Librarie Arthur Rousseau, 1925, v. I e V.

DOMAT, Jean. Les Loix Civiles dans leur ordre naturel. Paris: Pierre Aubouin, Pierre Emery et Charles Clouzier, $2^{\mathrm{a}}$ ed., 1697, t. I e II.

ESMEIN, Paul. Le fondement de la responsabilité contractuelle raprochée de la responsabilité délictuelle. in Revue Trimestrielle de Droit Civil. Paris, t. 32, p. 627-657, 1933.

GAIO. Institutas. Tradução de CRETELLA Jr., José, e CRETELLA, Agnes. São Paulo: RT, 2004.

GILISSEM, John. Introdução Histórica ao Direito. Tradução de HESPANHA, Antônio Manuel e MALHEIROS, Manuel Luís Macaísta. Lisboa: Fundação Calouste Gulbenkian, $5^{\mathrm{a}}$ ed., 2008.

GIORGI, Giorgio. Teoria delle obbligazione nel diritto moderno italiano: esposta con la scorta della dottrina e della giurisprudenza. Firense: Cammelli, $6^{\mathrm{a}}$ ed., 1903.

GOGliAnO, Daisy. Tratativas Pré-contratuais (bases de uma teoria). 2009. Tese (Livre Docência) - Faculdade de Direito da Universidade de São Paulo.

GOMES, Orlando. Transformações Gerais do Direito das Obrigações. São Paulo: RT, $2^{\mathrm{a}}$ ed, 1980.

GOROSTIAGA, Norberto. La causa en las obligaciones. Buenos Aires: Editorial Ideas, 1944.

GROSSO, Giuseppe. Lezioni di Sotria del Diritto Romano. Torino: Giapichelli, $5^{\mathrm{a}}$ ed., 1965.

Obbligazioni. Contenuto e requisiti dela prestazione.

Obbligazioni alternative e generiche. Torino: Giappichelli, 1947.

IRTI, Natalino. La polemica sui concetti giuridici. Rivista Trimestrale di Diritto e Procedura Civile. Milano, n. 1, Anno LVIII, p. 9-22, 2004. 
JOSSERAND, Louis. Cours de droit civil positive français. Paris: Sirey, $3^{\mathrm{a}}$ ed., 1938, t. II.

LEONE, Francesco. La negligenza nella colpa extracontrattuale e contrattuale. Rivista di Diritto Civile. Milano: anno VII, p. 84-103, 1915.

MARTON, G. Obligations de résultat et obligations de moyens. in Revue Trimestrielle de Droit Civil. Paris, t. 34, p. 499-543, 1935.

MAYNS, Charles. Cours de Droit Romain. Bruxelas: Bruylant-Christophe, 1877, v. 2. MAZEUD, Henri. Essai de classification des obligations: obligations contractuelles et extra-contractuelle; "obligations detérminées" et "obligations générales de prudence et diligence”. Revue Trimestrielle de Droit Civil. Paris, t. 35, p. 1-58, 1936.

MAZEAUD, Henri, MAZEAUD, Leon. Traité théorique et pratique de la responsabilité civile. Paris: Montchrestien, 1978, t. I.

MEIRA, Sílvio A. B. Instituições de Direito Romano. $3^{a}$ ed. São Paulo: Max Limonad, 1968.

A Lei das XII Tábuas. Rio de Janeiro: Forense, 1961.

MENGONI, Luigi . Obbligazioni "di risultato" e obbligazioni "di mezzi". Milano: Francesco Vallardi, 1954.

MINASSE, Elton. Contribuição ao estudo das obrigações "de meio" e de "resultado". 2005. Monografia (Mestrado) - Faculdade de Direito da Universidade de São Paulo.

OSTI, Giuseppe. Scritti Giuridici. Milano: Giuffrè, 1973.

PAGE, Henri de. Traité de Droit Civil Belge. Bruxelles: Emile Bruylant, 1942, t. VI.

PETIT, Eugène. Tratado Elementar de Direito Romano. trad. Jorge Luís Custódio Porto, Campinas: Russel, 2003.

PLANIOL, Marcel e RIPERT, Georges. Traité Pratique de Droit Civil Français. Paris: L.G.D.J., 1952.

PLANIOL, Marcel. Traité élémentaire de droit civil. Paris: L.G.D.J, 4ª ed., 1906, t. II. Examen Doctrinal. Droit Civil. (Contrats à titre onéreux). (Décisions publiées en 1887). Revue Critique de Legislation et Jurisprudence. Paris, n. 17, p. $273-296,1888$. 
PONTES DE MIRANDA, Francisco Cavalcante. Tratado de Direito Privado. Rio de Janeiro: Borsoi, $3^{\mathrm{a}}$ ed., 1970, v. I e XXII.

REMY, Philippe. La "responsabilité contractuelle": histoire d'um faux concept. in Revue Trimestrielle de Droit Civil. n. 96, p. 323-355, 1997.

RIPERT, George. A regra Moral nas Obrigações Civis. Tradução de OLIVEIRA, Osório. São Paulo: Saraiva, 1937.

ROBIN. Georges. Responsabilité notamment au point de vue de la clause de non garantie et du fardeau de la preuve en droit romain et en droit français. Paris: Imprimerie E. Pigelet, 1887.

ROPPO, Vincenzo. O contrato. Tradução de COIMBRA, Ana, e GOMES, M. Januário C. Coimbra: Almedina, 2009.

RUGGIERO, Roberto de. Instituições de Direito Civil. Tradução de SANTOS, Ary dos. São Paulo: Saraiva, 1958, v. 3.

RYN, Jean Van. Responsabilité aquiliènne et contrat en droit positif. Paris: Sirey, 1932. SAN JULIAN, Veronica. Objeto del Contrato. Barcelona: Bosch Editorial, 1996.

SATRCK, Boris. Domaine et fondement de la responsabilité sans faute. in Revue Trimestrielle de Droit Civil. Paris, t. LVI, p. 475-515, 1958.

TALAMANCA, Mario. Istituzioni di Diritto Romano. Milano: Giuffrè, 1990.

TUHR, Andreas Von. Tratado de las obligaciones. Tradução de ROCES, W. Madrid: Editorial Reus, 1934, v. I.

VARELA, João de Matos Antunes. Das Obrigações em Geral. Coimbra: Almedina, 10a ed., 2000 .

VILLEY, Michel. Esboço Histórico sobre o termo responsável. Tradução de CORRÊA, André Rodrigues. Revista de Direito GV. São Paulo, v. 1, n. 1, p. 143-147, maio 2005.

VINEY, Geneviève. Traité de Droit Civil. Les Obligations. La responsabilité: conditions. Coordenação de Jacques Ghestin. Paris: L.G.D.J., 1982.

VOLTERRA, Eduardo. Instituciones de Derecho Privado Romano. Madrid: Civitas, 1991. 
WIGNY, P. Responsabilité contractuelle et force majeure. in Revue Trimestrielle de Droit Civil. Paris, t. 34, 1935 